\title{
Mutasynthesis of Physostigmines in Myxococcus xanthus
}

Lea Winand, ${ }^{\dagger}$ Pascal Schneider, ${ }^{\star}$ Sebastian Kruth, ${ }^{\dagger}$ Nico-Joel Greven, ${ }^{\dagger}$ Wolf Hiller, ${ }^{\S}$ Marcel Kaiser, $\|, \nabla$ Jörg Pietruszka, ${ }^{\ddagger}, 0$ and Markus Nett*,†

†Department of Biochemical and Chemical Engineering, TU Dortmund University, Germany

Institute of Bioorganic Chemistry, Heinrich-Heine-University Düsseldorf at ForschungszentrumJülich, Germany

$\S$ Department of Chemistry and Chemical Biology, TU Dortmund University, Germany

"Parasite Chemotherapy Unit, Swiss Tropical and Public Health Institute, Basel, Switzerland

चUniversity of Basel, Basel, Switzerland

OInstitut für Bio- und Geowissenschaften: Biotechnologie (IBG-1), ForschungszentrumJülich, Germany

Table of contents

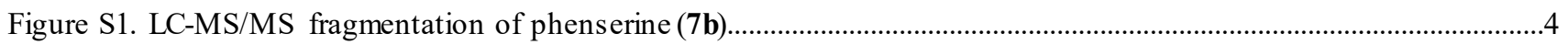

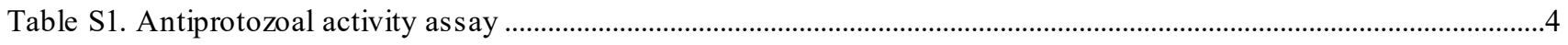

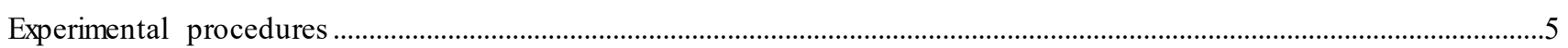

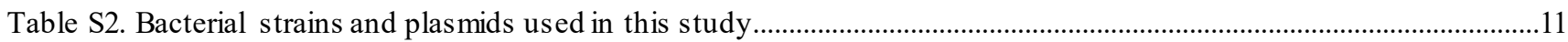

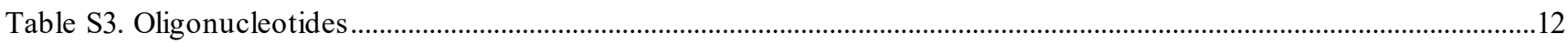

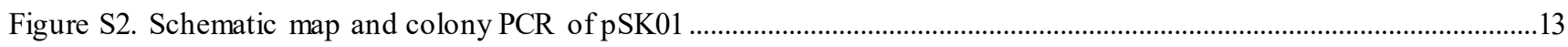

Figure S3. Schematic map and restriction analys is of pMEX01 ..............................................................................13

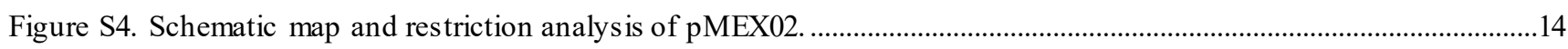

Figure S5. Schematic map, colony PCR and restriction analysis of pMEX03 ………............................................................14

Figure S6. Schematic map, colony PCR and restriction analysis of pMEX04 ………….......................................................15

Figure S7. Schematic map, colony PCR and restriction analysis of pMEX05 ...............................................................15

Figure S8. Schematic map, colony PCR and restriction analysis of pMEX06 ....................................................................16

Figure S9. Schematic map, colony PCR and restriction analysis of pMEX07........................................................................16

Figure S10. Schematic map, colony PCR and restriction analysis of pMEX08 ………………...........................................17

Figure S11. Schematic map, colony PCR and restriction analysis of pMEX09 …….............................................................17

Figure S12. Schematic map, colony PCR and restriction analysis of pMEX10 ……….........................................................18

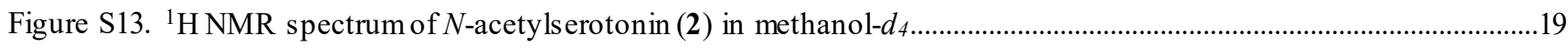

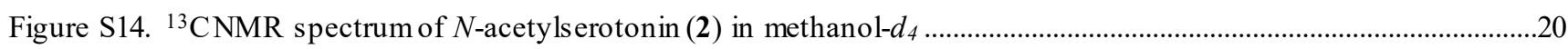

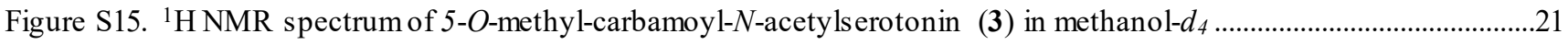

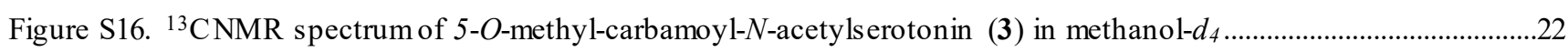

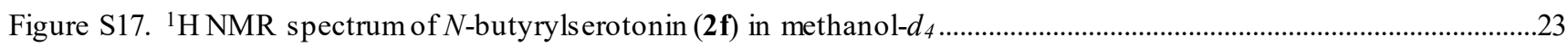

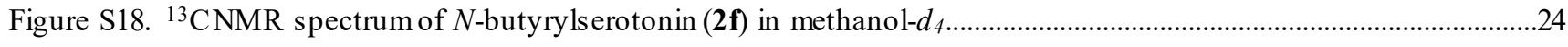

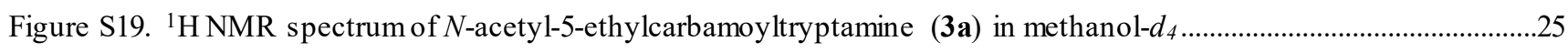

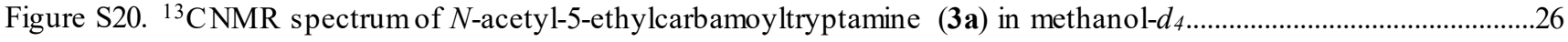

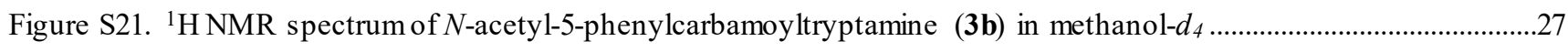

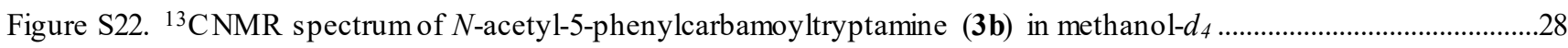


Figure S23. ${ }^{1} \mathrm{H}$ NMR spectrum of $N$-acetyl-5-fluorotryptamine (3c) in methanol- $d_{4}$ .29

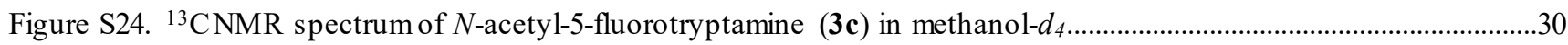

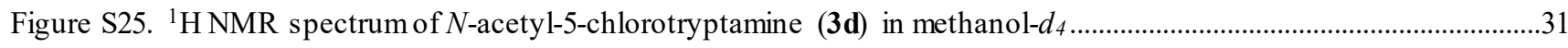

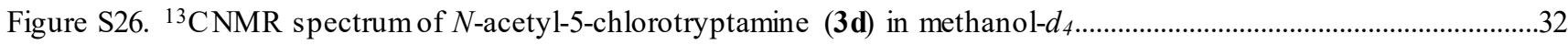

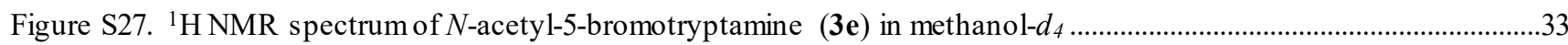

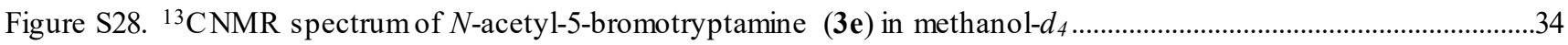

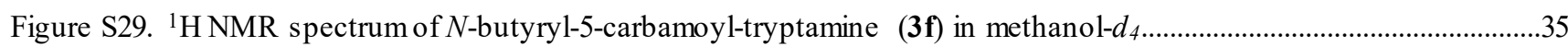

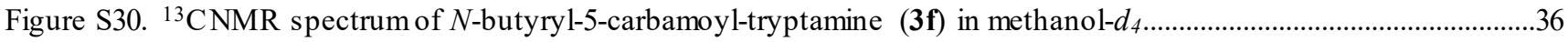

Figure S31. LC-MS chromatograms of the raw extracts from M. xanthus FB:pMEX07 (without fusion protein) and M. xanthus FB:pMEX05 (with fusion protein) fed with 3 .

Figure S32. Linear correlation between the total AUC of physostigmine (7) and es eroline (8) EICs and the phys ostigmine concentration ...37

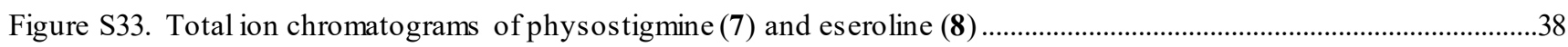

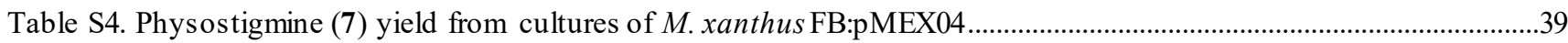

Table S5. Physostigmine (7) yield from cultures of M. xanthus FB:pMEX10 …....................................................................40

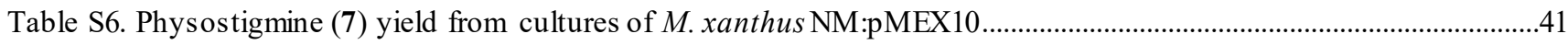

Table S7. Physostigmine (7) yield from cultures of M. xanthus NM:pMEX10 fed with $200 \mathrm{mg} / \mathrm{L} \mathrm{3} \mathrm{\ldots ...............................41}$

Figure S34. Physostigmine (7) yield in $\mathrm{mg}$ per liter cultivation volume .................................................................................42

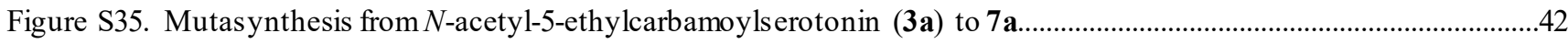

Figure S36. Mutasynthesis from $N$-acetyl-5-phenylcarbamoyls erotonin (3b) to phens erine (7b) .........................................43

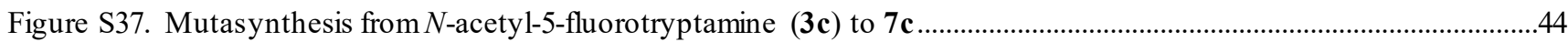

Figure S38. Mutasynthesis from $N$-acetyl-5-chlorotryptamine (3d) to 7d ............................................................................4

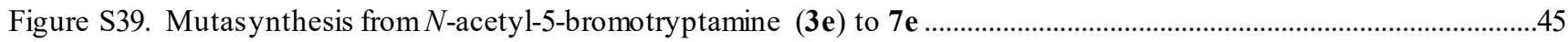

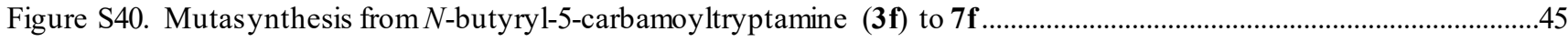

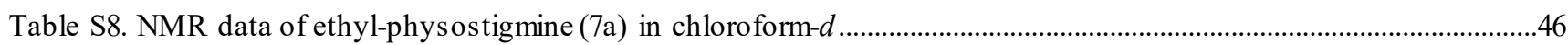

Figure S41. ${ }^{1}$ H NMR spectrum of ethyl-phys ostigmine $(\mathbf{7 a )}$ in chloroform- $d$........................................................................47

Figure S42. ${ }^{1} \mathrm{H}$-decoupled ${ }^{13} \mathrm{C}$ NMR spectrum of ethyl-phys ostigmine $(\mathbf{7 a})$ in chloroform- $d$..................................................48

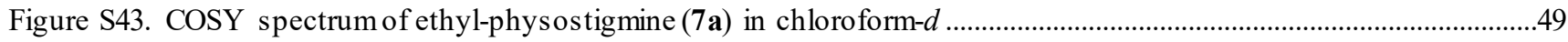

Figure S44. HSQC spectrum of ethyl-phys ostigmine (7a) in chloroform- $d$......................................................................50

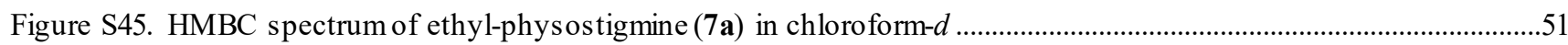

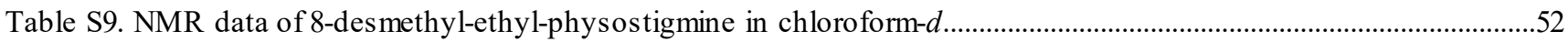

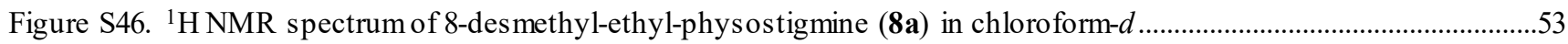

Figure S47. ${ }^{1} \mathrm{H}$-decoupled ${ }^{13} \mathrm{C}$ NMR spectrum of 8-des methyl-ethyl-physostigmine (8a) in chloroform- $d$............................54

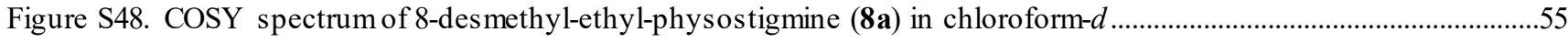

Figure S49. HSQC spectrum of 8-desmethyl-ethyl-phys os tigmine (8a) in chloroform- $d$......................................................56

Figure S50. HMBC spectrum of 8-desmethyl-ethyl-phys os tigmine (8a) in chloroform- $d$.....................................................57

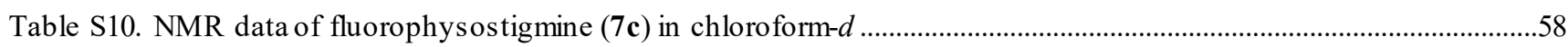

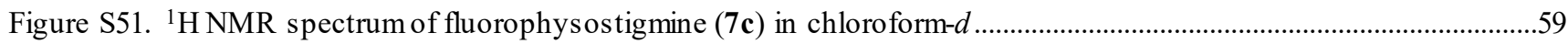

Figure S52. ${ }^{1} \mathrm{H}$-decoupled ${ }^{13} \mathrm{C}$ NMR spectrum of fluorophys ostigmine $(7 \mathbf{c})$ in chloroform- $d$.............................................60

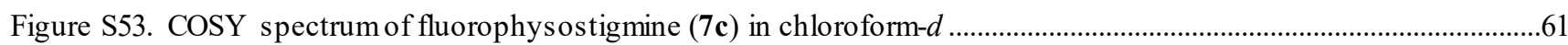

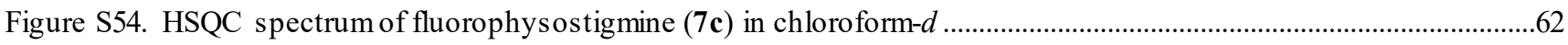

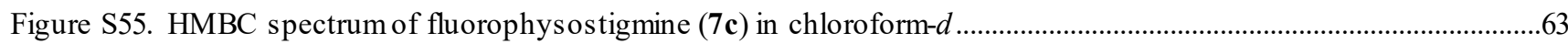

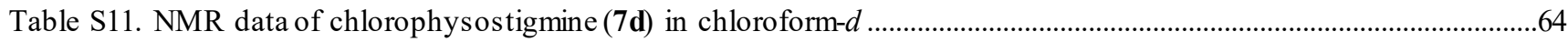

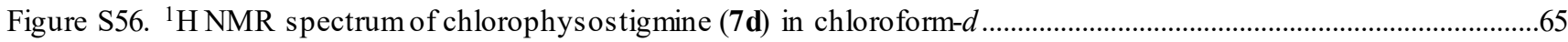


Figure S57. ${ }^{1} \mathrm{H}$-decoupled ${ }^{13} \mathrm{C}$ NMR spectrum of chlorophys ostigmine $(\mathbf{7 d})$ in chloroform- $d$...........................................66

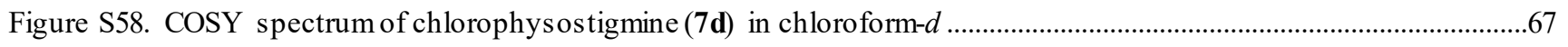

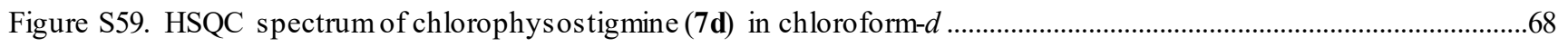

Figure S60. HMBC spectrum of chlorophysostigmine (7d) in chloroform-d …..............................................................69

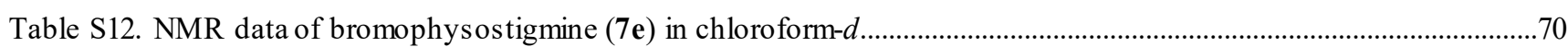

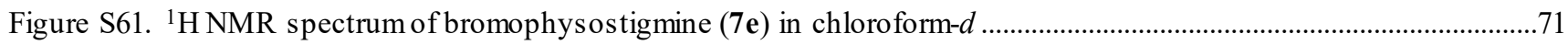

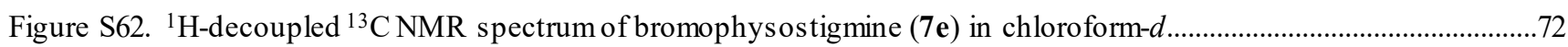

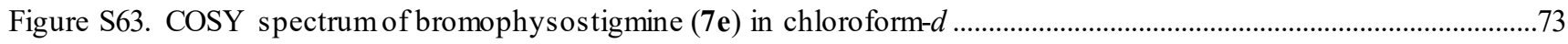

Figure S64. HSQC spectrum of bromophysostigmine (7e) in chloroform- $d$...................................................................74

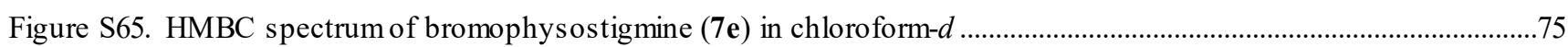

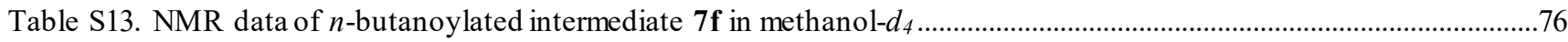

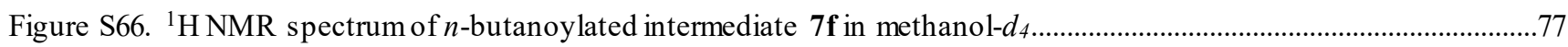

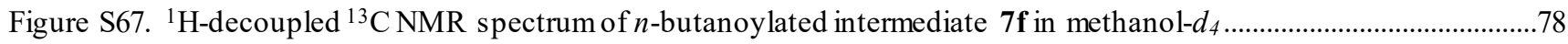

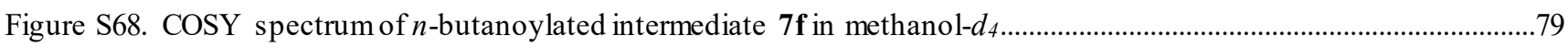

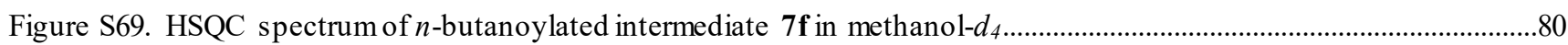

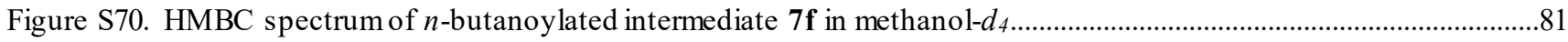

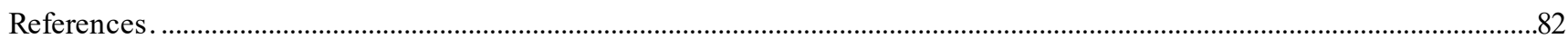


A

A

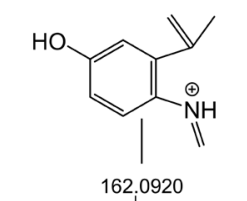

$\left.\right|^{162.0920}$ HO
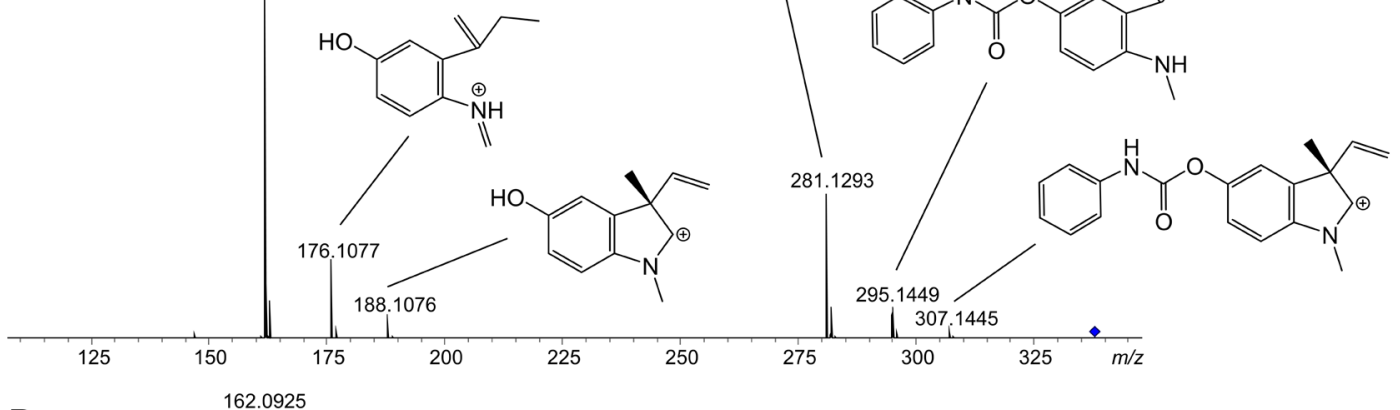

B

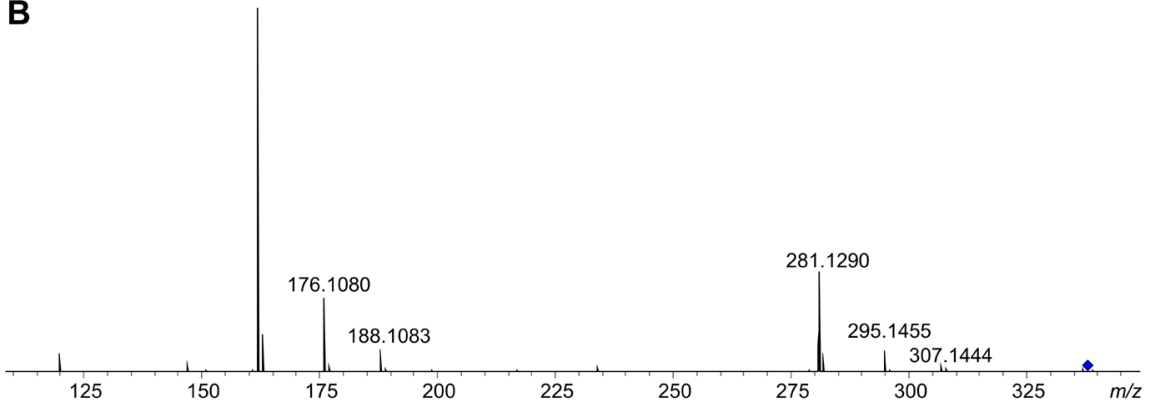

Figure S1. LC-MS/MS fragmentation of a commercial standard (Biomol) of phenserine (7b). The assignment of fragments was according to literature reports ${ }^{1}$ (A). LC-MS/MS fragmentation of $\mathbf{7 b}$ produced by $M$. xanthus NM:pMEX10 after feeding of 3b (B).

Table S1. Antiprotozoal activity assay.

\begin{tabular}{|c|c|c|c|c|}
\hline Compound & $\begin{array}{c}\text { T. b. rhodesiense } \\
\mathrm{IC}_{50}[\mu \mathrm{M}]\end{array}$ & $\begin{array}{c}\text { T. cruzi } \\
\mathrm{IC}_{50}[\mu \mathrm{M}]\end{array}$ & $\begin{array}{l}\text { L. donovani } \\
\mathrm{IC}_{50}[\mu \mathrm{M}]\end{array}$ & $\begin{array}{l}\text { P. falciparum } \\
\mathrm{IC}_{50}[\boldsymbol{M} \mathrm{M}] \\
\end{array}$ \\
\hline melars oprol & 0.01 & & & \\
\hline benznidazole & & 2.1 & & \\
\hline miltefosine & & & 0.48 & \\
\hline chloroquine & & & & 0.01 \\
\hline 7 & 58.7 & 188.5 & 277.1 & 28.9 \\
\hline $7 a$ & 112.7 & 238.8 & 218.4 & 50.7 \\
\hline $7 c$ & 228.3 & $>300$ & 289.2 & 168.0 \\
\hline $7 d$ & 40.2 & 216.5 & 252.6 & 90.2 \\
\hline $7 e$ & 55.5 & 258.4 & 262.0 & 111.7 \\
\hline $7 \mathrm{f}$ & 143.1 & $>300$ & 303.8 & 69.0 \\
\hline
\end{tabular}


Strains, nucleic acids and plasmids. The bacterial strains and plasmids used in this study are described in Table S2. The type strain of $M$. xanthus ${ }^{2}$ was acquired from the German Collection of Microorganisms and Cell Cultures (DSMZ), whereas the nonmotile M. xanthus mutant ${ }^{3}$ was purchased from the American Type Culture Collection (ATCC). The genes psmA-F from the physostigmine biosynthetic gene cluster (GenBank accession number KF201694) were synthesized by ATG:biosynthetics. The genome sequence of M. xanthus, covering the promoter regions used in this work, was retrieved from GenBank (accession number NC_008095).

Growth conditions and nucleic acid extraction. E. coli TOP10 and E. coli DH5 $\alpha$ were cultured in liquid or solidified lysogeny broth (LB) medium at $37^{\circ} \mathrm{C}$. Liquid cultures were shaken at $180 \mathrm{rpm}$. M. xanthus strains were routinely grown in CTPM medium

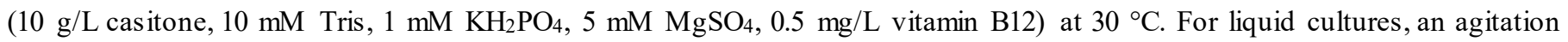
speed of $130 \mathrm{rpm}$ was applied. The antibiotic kanamycin $(50 \mu \mathrm{g} / \mathrm{mL})$ was used as selection marker. Genomic DNA of $M$. xanthus was is olated using the DNeasy Blood\&Tissue Kit (Qiagen). Plasmid DNA was obtained from E. coli cultures using the NucleoSpin Plasmid (NoLid) Mini or NucleoBond Xtra Midi Kit (Macherey-Nagel). Nucleic acids embedded in agarose gels were isolated using the NucleoSpin Gel and PCR Clean-up Mini Kit (Macherey-Nagel).

Generation of pMEX01. All expression plasmids used in this study originate from pMEX01, which is a derivative of pZJY156 ${ }^{4}$ with an extended multiple cloning site and in which the ampicillin resistance cassette was removed. Moreover, the terminator sequence of the $m l p A$ gene of $M$. xanthus DK1622 $2^{5}$ was added downstream the multiple cloning site. To achieve these modifications in pZJY156, the respective vector was amplified by inverse PCR using the primer pair P01/P02 (Table S3) in order to delete the ampicillin resistance cassette. The ends were joint by ligation using a T4 DNA ligase (Thermo Scientific) and the resulting plasmid pSK01 (Figure S2) was transferred to chemically competent E. coli DH5a cells. Subsequently, the extended multiple cloning site and the terminator sequence were introduced by annealed oligo cloning. For this purpose, pSK01 was cut with EcoRI and XbaI (FastDigest enzymes, Thermo Scientific) and then ligated with the annealed oligonucleotides P03/04. The ligation product was transferred to chemically competent $E$. coli $\mathrm{DH} 5 \alpha$ cells to finally give pMEX01. The correct identity of pMEX01 was validated by restriction analysis and sequencing (Figure S3).

Construction of psm expression plasmids. The promoter region of the pilA gene $\left(\mathrm{P}_{\text {pila }}\right)$ and the extended promoter region fused to the first $45 \mathrm{bp}$ of the pilA gene ( $\left.\mathrm{P}_{\text {pila fus }}\right)$ were amplified by overhang PCR from genomic DNA of M. xanthus FB using the primer pairs P05/P06 and P07/P08 and the Phusion High-Fidelity PCR Master Mix (Thermo Scientific) according to the manufacturer's specification. In this way, the PCR products of $\mathrm{P}_{\text {pila }}$ and $\mathrm{P}_{\text {pilaf } f \text { fus }}$ were endowed with flanking restriction sites. The PCR products were ligated via their ClaI-EcoRI and EcoRI-SacI sites into pMEX01 to create the vectors pMEX02 and pMEX03. The two latter plasmids were introduced into E. coli $\mathrm{DH} 5 \alpha$ or $E$. coli TOP10 by chemical transformation. Subsequently, the biosynthesis genes $p s m A-F$ were transferred from pUC57-psmA-F into the corresponding ScaI site of pMEX03 by restriction ligation cloning to give the expression plasmid pMEX04 (Figure S6). The remaining plasmids were constructed using circular polymerase extension cloning (CPEC). ${ }^{6}$ The CPEC reaction was generally conducted with the Phusion High-Fidelity PCR Master Mix (Thermo Scientific) and different insert-vector ratios $(3: 1,9: 1,12: 1)$ at the following conditions: 1 cycle of $98{ }^{\circ} \mathrm{C}$ for $30 \mathrm{~s}, 20$ cycles of $98{ }^{\circ} \mathrm{C}$ for $10 \mathrm{~s}$, $68{ }^{\circ} \mathrm{C}$ for $30 \mathrm{~s}, 72{ }^{\circ} \mathrm{C}$ for $30 \mathrm{~s} / \mathrm{kb}, 1$ cycle of $72{ }^{\circ} \mathrm{C}$ for $10 \mathrm{~min}$. For construction of pMEX05 and pMEX06, psmD and psmC were amplified with primer pairs $\mathrm{P} 09 / \mathrm{P} 10$ and P11/P12, respectively. The vector pMEX03 was linearized with the restriction endonuclease ScaI and simultaneously dephosphorylated using the FastAP Alkaline Phosphatase (ThermoScientific). Subsequently, the purified PCR products of $p s m D$ or $p s m C$ and the linearized pMEX03 were combined by CPEC. To close remaining nicks in the backbone of pMEX05 or pMEX06, the CPEC reaction products were introduced into E. coli TOP10. Plasmid pMEX07 was synthesized by exchanging the promoter region in pMEX05. For this purpose, pMEX05 was digested with EcoRI and Ecl136II to

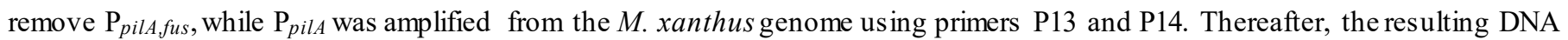
fragments were connected by CPEC. The construct $\mathrm{P}_{\text {pila fus }}$ - $s m C$ was amplified from pMEX06 with the primers P15/P16 and equipped with overhangs. The PCR product and the Bst1107I-digested pMEX05 were merged by CPEC as described before to yield pMEX08. For creation of plasmid pMEX09, the gene $p \operatorname{sm} B$ was amplified using the primer pair P17/P18 and integrated into the ScaI site of pMEX03. Afterwards, $\mathrm{P}_{\text {pilA.fus }}$ psmB was amplified with P19 and P20 and ligated into the Bst1107I-digested pMEX08 to finally give the multimonocistronic expression plasmid pMEX10 (Figure S12). The identity of all generated vectors was verified by restriction mapping and/or colony PCR using the primers P21 and P22 (Figures S2-S12). 
Transformation of M. xanthus. A seed culture of M. xanthus was used to inoculate $50 \mathrm{~mL}$ CTPM medium to an OD $600 \mathrm{~nm}$ of 0.05 . The culture was incubated over night at $30^{\circ} \mathrm{C}$. Two milliliters of the cell culture were harvested by centrifugation $(8000 \mathrm{rpm}, 10$ ${ }^{\circ} \mathrm{C}, 10 \mathrm{~min}$ ). Afterwards, the supernatant was discarded and the cell pellet was washed three times with ice-cooled water. The cell pellet was resuspended in $50 \mu \mathrm{L}$ water and transferred to a $1 \mathrm{~mm}$ electroporation cuvette. After addition of 0.5 to $1.5 \mu \mathrm{g}$ plasmid DNA, the electroporation pulse was applied at the following conditions: $650 \mathrm{~V}, 400 \Omega, 25 \mu \mathrm{F}$. The cells were regenerated in $5 \mathrm{~mL}$ CTPM at $30^{\circ} \mathrm{C}$ for 5 to 6 hours. Afterwards, the cells were centrifuged (5000 rpm, RT, 3 min) and resuspended in $500 \mu \mathrm{L}$ medium and, eventually, spread onto CTPM agar plates containing $50 \mu \mathrm{g} / \mathrm{mL}$ kanamycin. The agar plates were incubated at $30{ }^{\circ} \mathrm{C}$ until growth of M. xanthus transformants was observed.

Preparation of $\mathrm{N}$-acetyls erotonin (2). Sodium borohydride (2.57 g, $68.3 \mathrm{mmol})$ was cautiously added to a stirred solution of 5benzyloxyindole-3-acetonitrile $(2.50 \mathrm{~g}, 9.75 \mathrm{mmol})$, acetic anhydride $(1.95 \mathrm{~mL}, 9.75 \mathrm{mmol})$ and nickel(II) chloride hexahydrate $(2.30 \mathrm{~g}, 9.75 \mathrm{mmol})$ in methanol $(100 \mathrm{~mL})$ at $0{ }^{\circ} \mathrm{C}$. A black precipitate was formed following a vigorous reaction and once the reaction had subsided, stirring was continued at room temperature for $20 \mathrm{~min}$. Methanol was removed under reduced pressure and the residue was dissolved in ethyl acetate $(100 \mathrm{~mL})$ and $\mathrm{NaHCO}_{3}(25 \mathrm{~mL})$, filtered, and the precipitate was washed with ethyl acetate $(3 \times 25 \mathrm{~mL})$. The combined organic layer was dried $\left(\mathrm{Na}_{2} \mathrm{SO}_{4}\right)$ and evaporated under reduced pressure to give the crude $N$ \{2-[5-(benzyloxy)-1H-indol-3-yl]ethyl\}acetamide as light brown viscous oil. Next, a mixture of the obtained crude product, ammonium formate $(3.07 \mathrm{~g}, 48.8 \mathrm{mmol})$, and $10 \% \mathrm{Pd} / \mathrm{C}(0.11 \mathrm{~g}, 1.04 \mathrm{mmol})$ in ethanol $(100 \mathrm{~mL})$ was heated at reflux for $30 \mathrm{~min}$. The filtrate was evaporated under reduced pressure and purified by column chromatography $\left(\mathrm{CH}_{2} \mathrm{Cl}_{2} / \mathrm{MeOH}, 9: 1\right)$ to give $1.80 \mathrm{~g}$ ( $8.26 \mathrm{mmol}, 85 \%$ over 2 steps) of pure 2 as a pale brown/yellow viscous oil. The spectral data of 2 were identical with those previously reported (Figures S13 and S14). ${ }^{7}$

Preparation of 5-O-methyl-car bamoyl- $\boldsymbol{N}$-acetylserotonin (3). A solution of $N$-acetylserotonin (2) (1.00 g, $4.59 \mathrm{mmol})$ and trimethylamine $(3.20 \mathrm{~mL}, 22.9 \mathrm{mmol})$ in dry THF $(15 \mathrm{~mL})$ was stirred for $15 \mathrm{~min}$ under an inert atmosphere. To this solution, $N$ methylcarbamoyl chloride $(1.07 \mathrm{~g}, 11.5 \mathrm{mmol})$ and DMAP $(0.06 \mathrm{~g}, 0.46 \mathrm{mmol})$ were added and the reaction was stirred at $45^{\circ} \mathrm{C}$ using a heating mantle for 16 hours. The reaction was quenched with $20 \mathrm{~mL}$ saturated ammonium formate solution and extracted three times with ethyl acetate. The remaining residue was concentrated under reduced pressure. After column chromatography $\left(\mathrm{CH}_{2} \mathrm{Cl}_{2} / \mathrm{MeOH}, 9: 1\right) 1.10 \mathrm{~g}$ of $\mathbf{3}(3.99 \mathrm{mmol}, 87 \%)$ were obtained as a white foam. The spectraldata of $\mathbf{3}$ were identical with those previously reported (Figures S15 and S16). ${ }^{8}$

Heterologous production of physostigmine in M. xanthus. For the production of physostigmine, four Erlenmeyer flasks containing 1 L CTPM medium and kanamycin were inoculated with M. xanthus FB:pMEX04. One culture served as a negative control, the remaining cultures were supplemented with $50 \mathrm{mg} / \mathrm{L}$ serotonin (1), $N$-acetylserotonin (2) or 5-O-methyl-carbamoyl- $N$-acetylserotonin (3) as substrates for triggering physostigmine biosynthesis. After 7 days of cultivation, all cultures were extracted with ethylacetate. The culture extracts were analyzed by liquid chromatography-mass spectrometry (LC-MS) using a Nucleoshell RP18 column (Macherey-Nagel) and an Agilent 1260 Infinity LC System connected to a Compact Q TOF mass spectrometer (Bruker Daltonics). A physostigmine standard was obtained from Alfa aesar.

Evaluation of the gene fusion strategy. Since the creation of fusion genes between a highly expressed native gene and the gene of interest can improve a heterologous protein expression, ${ }^{9}$ we tested the influence of the gene fusion between the first $45 \mathrm{bp}$ of the pilA gene and $p s m D$ on the production of 4 . Because PilA is necessary for the synthes is of type IV pili and thereby involved in the gliding motility of M. xanthus, one can assume that the pilA gene is highly expressed in M. xanthus..$^{10}$ The strains M. xanthus FB:pMEX05 (with fusion protein) and M. xanthus FB:pMEX07 (without fusion protein) were cultured in $100 \mathrm{~mL}$ CTPM for 3 days at $30{ }^{\circ} \mathrm{C}$ and $130 \mathrm{rpm}$. Before inoculation, the fermentation medium was supplemented with $40 \mathrm{mg} / \mathrm{L}$ 5-O-methyl-carbamoyl$N$-acetylserotonin (3). At the end of cultivation, 3\% Amberlite XAD7HP (Sigma Aldrich) was added to the cultures. After 2 hours incubation, the XAD7 was filtered and washed with $100 \mathrm{~mL}$ water. Adsorbed compounds were eluted by flushing the resin with $100 \mathrm{~mL}$ methanol. The eluate was dried in a rotary evaporator (Heidolph) and subsequently resuspended in $5 \mathrm{~mL}$ methanol. The raw extracts were analyzed by LC-MS (Figure S31). In presence of the fusion protein, significantly higher amounts of 4 were formed. 
Quantification of physostigmine production level. For determination of the physostigmine (7) titer, the respective M. xanthus expression strains were grown in $100 \mathrm{~mL}$ CTPM, supplemented with $40 \mathrm{mg} / \mathrm{L}$ of $\mathbf{3}$, for 3 days at $30{ }^{\circ} \mathrm{C}$ and $130 \mathrm{rpm}$. In another experiment, M. xanthus NM:pMEX10 was grown in the presence of $200 \mathrm{mg} / \mathrm{L}$ of 3 . Physostigmine (7) was recovered from the fermentation broth using 3\% Amberlite XAD7HP (Sigma Aldrich) as described above. The product formation was evaluated by LC-MS. For quantification, the signal of the analyte was referred to a calibration curve obtained with commercial physostigmine (Alfa aesar) (Figure S32). Since physostigmine consistently hydrolyzes to eseroline under the MS conditions used (Figure S33), the combined areas of the physostigmine and eseroline signals were used to determine the physostigmine concentration. All data were reproduced by culturing at least four different clones per expression strain in four to six independent cultures. For comparison of the variance, the coefficient of variation was calculated from the average physostigmine yield and the standard deviation.

General experimental procedures for the synthesis of $2 \mathrm{f}$ and $3 \mathrm{a}-\mathrm{f}$. If not otherwise mentioned, all chemicals were obtained from commercial sources and used without any further purification. The solvents $\mathrm{CH}_{2} \mathrm{Cl}_{2}, \mathrm{THF}$, and toluene were purchased from commercial sources and dried using an MB-SPS-800 solvent purification system. Furthermore, all reactions were performed under inert conditions ( $\mathrm{N}_{2}$ or Ar atmosphere) utilizing the Schlenk technique if stated so. The TLC-foil Polygram SilG/UV254 by Macherey-Nagel was used as a stationary phase in thin layer chromatography. TLC plates were stained using either a $\mathrm{KMnO}_{4}$ solution or CAM (Cerium Ammonium Molybdate) solution. Most products were isolated using preparative column chromatography. The silica gel $(0.040-0.063 \mathrm{~mm})$ was provided by Merck; as mobile phase mixtures, petrol ether and ethyl acetate or $\mathrm{CH}_{2} \mathrm{Cl}_{2}$ and methanol were used. The ${ }^{1} \mathrm{H}$ and ${ }^{13} \mathrm{C}$ NMR spectra of all synthesized precursors were recorded on a Bruker Avance DRX 600 spectrometer.

Preparation of $\mathrm{N}$-butyryls erotonin (2f). Sodium borohydride (964 mg, $25.6 \mathrm{mmol}$ ) was cautiously added to a stirred solution of 5-benzyloxyindole-3-acetonitrile (900 mg, $3.66 \mathrm{mmol})$, butyric anhydride $(1.20 \mathrm{~mL}, 7.32 \mathrm{mmol})$ and nickel (II) chloride hexahydrate $(1.31 \mathrm{~g}, 5.5 \mathrm{mmol})$ in methanol $\left(0.05 \mathrm{mmol} \cdot \mathrm{mL}^{-1}\right)$ at $0{ }^{\circ} \mathrm{C}$ using an ice bath. A black precipitate was formed following a vigorous reaction and once the reaction had subsided, stirring was continued at room temperature for $20 \mathrm{~min}$. Methanol was removed under vacuum and the residue was dissolved in ethyl acetate $(100 \mathrm{~mL})$ and $\mathrm{NaHCO}_{3}(25 \mathrm{~mL})$, filtered, and the precipitate was washed with ethylacetate $(3 \times 25 \mathrm{~mL})$. The combined organic layer was dried $\left(\mathrm{Na}_{2} \mathrm{SO}_{4}\right)$ and evaporated under reduced pressure to give the crude 5-benzyloxy- $N$-alkyl serotonin. ${ }^{7}$ Next, a mixture of the obtained crude product, ammonium formate (1.15 g, 18.3 $\mathrm{mmol})$ and $10 \% \mathrm{Pd} / \mathrm{C}(40 \mathrm{mg}, 0.37 \mathrm{mmol})$ in ethanol $(100 \mathrm{~mL})$ was heated at reflux for $30 \mathrm{~min}$. The filtrate was evaporated under reduced pressure. After column chromatography $\left(\mathrm{CH}_{2} \mathrm{Cl}_{2} / \mathrm{MeOH}, 9: 1\right) 750 \mathrm{mg}(3.05 \mathrm{mmol}, 80 \%)$ of $\mathbf{2 f}$ were obtained as a pale bown oil. NMR data of $\mathbf{2 f}$ are displayed in Figures S17 and S18.

$N$-Butyrylserotonin (2f): ESIHRMS $m / z 247.1443$ (calcd for $\mathrm{C}_{14} \mathrm{H}_{19} \mathrm{~N}_{2} \mathrm{O}_{2}, 247.1441$ )

Preparation of $N$-acetyl-5-ethylcarbamoyltryptamine (3a). A solution of $N$-acetylserotonin (2) (195 mg, $0.68 \mathrm{mmol})$ and trimethylamine $(475 \mu \mathrm{L}, 3.40 \mathrm{mmol})$ in dry THF $\left(0.07 \mathrm{mmol} \cdot \mathrm{mL}^{-1}\right)$ was stirred for $15 \mathrm{~min}$ under inert atmosphere. To this solution ethyl is ocyanide $(59 \mu \mathrm{L}, 0.75 \mathrm{mmol})$ and DMAP $(17 \mathrm{mg}, 0.14 \mathrm{mmol})$ were added and reaction was stirred at $0-23{ }^{\circ} \mathrm{C}$ for $15 \mathrm{~min}$. An ice bath was used for cooling. Reaction was monitored by TLC till full conversion was obtained. Reaction was then quenched with $20 \mathrm{~mL}$ of saturated ammonium chloride solution and extracted three times with ethyl acetate. The combined organic layers were washed with brine, dried over $\mathrm{Na}_{2} \mathrm{SO}_{4}$, filtered, and concentrated in vacuo. After column chromatography $\left(\mathrm{CH}_{2} \mathrm{Cl}_{2} / \mathrm{MeOH}\right.$, 9:1) $132 \mathrm{mg}(0.46 \mathrm{mmol}, 68 \%)$ of $\mathbf{3 a}$ were obtained as a white foam. NMR data of 3a are displayed in Figures S19 and S20.

$N$-Acetyl-5-ethylcarbamoyltryptamine (3a): ESIHRMS m/z 290.1503 (calcd for $\mathrm{C}_{15} \mathrm{H}_{20} \mathrm{~N}_{3} \mathrm{O}_{3}, 290.1504$ )

Preparation of $N$-acetyl-5-phenylc arbamoyltryptamine (3b). A solution of $N$-acetylserotonin (2) (555 $\mathrm{mg}, 1.65 \mathrm{mmol})$ and trimethylamine $(690 \mu \mathrm{L}, 4.94 \mathrm{mmol})$ in dry THF $\left(0.07 \mathrm{mmol} \cdot \mathrm{mL}^{-1}\right)$ was stirred for $15 \mathrm{~min}$ under inert atmosphere. To this solution phenyl isocyanide (197 $\mu \mathrm{L}, 1.82 \mathrm{mmol})$ and DMAP (35 mg; $0.32 \mathrm{mmol})$ were added and reaction was stirred at $23-40{ }^{\circ} \mathrm{C}$ for 30 min using a heating mantle. Reaction was monitored by TLC till full conversion was obtained. Reaction was then quenched with $20 \mathrm{~mL}$ of saturated ammonium chloride solution and extracted three times with ethyl acetate. The combined organic layers were washed with brine, dried over $\mathrm{Na}_{2} \mathrm{SO}_{4}$, filtered, and concentrated in vacuo. After column chromatography $\left(\mathrm{CH}_{2} \mathrm{Cl}_{2} / \mathrm{MeOH}, 9: 1\right)$ $420 \mathrm{mg}$ ( $1.25 \mathrm{mmol}, 76 \%)$ of $\mathbf{3 b}$ were obtained as a pale orange foam. NMR data of $\mathbf{3 b}$ are displayed in Figures S21 and S22.

$N$-Acetyl-5-phenylcarbamoyltryptamine (3b): ESIHRMS m/z 338.1500 (calcd for $\mathrm{C}_{19} \mathrm{H}_{20} \mathrm{~N}_{3} \mathrm{O}_{3}, 338.1504$ ) 
General procedure for synthesis of various $N$-acetyl-5-halogenated tryptamines (3c, 3d, 3e). Acetic anhydride (1.10 equiv.) and DMAP (1.1 mmol, 0.20 equiv.) were added to a solution of respective tryptamine ( $5.6 \mathrm{mmol}, 1.0$ equiv.) and trimethylamine (5.6 mmol, 1.0 equiv.) in dry THF $\left(0.07 \mathrm{mmol} \cdot \mathrm{mL}^{-1}\right)$. Afterwards, the reaction was stirred at $0-23{ }^{\circ} \mathrm{C}$ for $15 \mathrm{~min}$. An ice bath was used for cooling. Reaction was monitored by TLC till full conversion was obtained. Reaction was then quenched with $20 \mathrm{~mL}$ of saturated ammonium chloride solution and extracted three times with ethyl acetate. The combined organic layers were washed with brine, dried over $\mathrm{Na}_{2} \mathrm{SO}_{4}$, filtered, and concentrated in vacuo. After column chromatography $\left(\mathrm{CH}_{2} \mathrm{Cl}_{2} / \mathrm{MeOH}, 9: 1\right)$ the product was obtained.

Preparation of $\mathrm{N}$-acetyl-5-fluorotryptamine (3c). Compound $\mathbf{3 c}$ was obtained according to standard procedure (3c, 3d, 3e). As a substrate 5-fluorotryptamine was used. After column chromatography $\left(\mathrm{CH}_{2} \mathrm{Cl}_{2} / \mathrm{MeOH}, 9: 1\right) 350 \mathrm{mg}(1.59 \mathrm{mmol}, 72 \%)$ of 3c were obtained as a white foam. NMR data of $\mathbf{3 c}$ are displayed in Figures S23 and S24.

$N$-Acetyl-5-fluorotryptamine (3c): ESIHRMS m/z 221.1086 (calcd for $\mathrm{C}_{12} \mathrm{H}_{15} \mathrm{FN}_{2} \mathrm{O}, 221.1085$ )

Preparation of $\boldsymbol{N}$-acetyl-5-chlorotryptamine (3d). Compound 3d was obtained according to standard procedure (3c, 3d, 3e). As a substrate 5-chlorotryptamine was used. After column chromatography $\left(\mathrm{CH}_{2} \mathrm{Cl}_{2} / \mathrm{MeOH}, 9: 1\right) 400 \mathrm{mg}(0.84 \mathrm{mmol}, 80 \%)$ of 3d were obtained as a pale yellow foam. NMR data of $\mathbf{3 d}$ are displayed in Figures S25 and S26.

$N$-Acetyl-5-chlorotryptamine (3d): ESIHRMS m/z 237.0789 (calcd for $\mathrm{C}_{12} \mathrm{H}_{15} \mathrm{ClN}_{2} \mathrm{O}, 237.0789$ )

Preparation of $\mathrm{N}$-acetyl-5-bromotryptamine (3e). Compound $\mathbf{3 e}$ was obtained according to standard procedure (3c, 3d, 3e). As a substrate 5-bromotryptamine was used. After column chromatography $\left(\mathrm{CH}_{2} \mathrm{Cl}_{2} / \mathrm{MeOH}, 9: 1\right) 235 \mathrm{mg}(1.69 \mathrm{mmol}, 47 \%)$ of $\mathbf{3 e}$ were obtained as a yellow oil. NMR data of $3 \mathbf{e}$ are displayed in Figures S27 and S28.

$N$-Acetyl-5-bromotryptamine (3e): HRESIMS $m / z 281.0287$ (calcd for $\mathrm{C}_{12} \mathrm{H}_{15} \mathrm{BrN}_{2} \mathrm{O}, 281.0284$ )

Preparation of $\mathrm{N}$-butyryl-5-carbamoyl-tryptamine (3f). A solution of $\mathrm{N}$-butyrylserotonin (2f) (300 $\mathrm{mg}, 1.00 \mathrm{mmol})$ and triethylamine (700 $\mu \mathrm{L}, 5.00 \mathrm{mmol})$ in dry THF $\left(0.07 \mathrm{mmol} \cdot \mathrm{mL}^{-1}\right)$ was stirred for $15 \mathrm{~min}$ under inert atmosphere. To this solution $N$ methylcarbamoyl chloride (185 mg, $2.00 \mathrm{mmol})$ and DMAP $(25 \mathrm{mg}, 0.20 \mathrm{mmol})$ were added. The reaction was stirred at $45{ }^{\circ} \mathrm{C}$ using a heating mantle for 16 hours. Reaction was then quenched with $20 \mathrm{~mL}$ of saturated ammonium chloride solution and extracted three times with ethyl acetate. The combined organic layers were washed with brine, dried over $\mathrm{Na}_{2} \mathrm{SO}_{4}$, filtered, and concentrated in vacuo. After column chromatography $\left(\mathrm{CH}_{2} \mathrm{Cl}_{2} / \mathrm{MeOH}, 9: 1\right) 140 \mathrm{mg}(0.46 \mathrm{mmol}, 45 \%)$ of $\mathbf{3 f}$ were obtained as a pale yellow foam. NMR data of $\mathbf{3} \mathbf{f}$ are displayed in Figures S29 and S30.

$N$-Butyryl-5-carbamoyl-tryptamine (3f): HRESIMS $m / z 304.1657$ (calcd for $\mathrm{C}_{16} \mathrm{H}_{22} \mathrm{~N}_{3} \mathrm{O}_{3}, 304.1656$ )

Production, isolation and purification of physostigmine derivatives. The mutasynthetic production of physostigmine derivatives was performed using the mutant strain $M$. xanthus NM:pMEX10. The mutant strain was cultivated in 5 L Erlenmeyer flasks containing 1 L CTPM medium that was supplemented with kanamycin and $60 \mathrm{mg} / \mathrm{L}$ of $N$-acetyl-5-ethylcarbamoyltryptamine (3a), $\mathrm{N}$-acetyl-5-phenylcarbamoyltryptamine (3b), $\mathrm{N}$-acetyl-5-fluorotryptamine (3c), $\mathrm{N}$-acetyl-5-chlorotryptamine (3d), $\mathrm{N}$-acetyl-5-bromotryptamine (3e) or $N$-butyryl-5-carbamoyl-tryptamine (3f). The cultures were incubated for 7 days at $30{ }^{\circ} \mathrm{C}$ and $130 \mathrm{rpm}$. After three days of incubation, casitone was fed at a rate of $1.25 \mathrm{~g} / \mathrm{d}$ in order to reach higher cell densities and to prolong the growth phase. Product isolation was conducted using 3\% Amberlite XAD7HP as described above. The presence of compounds 7a-f in the bacterial raw extracts was validated via LC-MS analyses. After feeding of 3a, we observed a new peak (8a) with a mass corresponding to a demethylated ethylphysostigmine. Since phenserine (7b) was produced in low quantities, the identity of this compound was proven by LC-MS/MS analysis and comparison to an external standard (Biomol). The remaining physostigmine derivatives produced via mutasynthesis were purified in two consecutive reversed phase HPLC steps on a preparative HPLC system (Shimadzu) using a Nucleodur 100-5 C18 VarioPrep column (Macherey-Nagel) as well as methanol and water with $0.1 \%$ trifluoracetic acid as mobile phases. The chromatographic conditions for the purification of each compound are listed in the following:

7a and 8a: Step 1 - flow rate: $6 \mathrm{~mL} / \mathrm{min} ; 70 \%$ methanol over $6 \mathrm{~min}, 70 \%$ to $83 \%$ methanol within $4 \mathrm{~min}, 83 \%$ to $100 \%$ methanol within $3 \mathrm{~min}, 100 \%$ methanol over $2 \mathrm{~min}, 100 \%$ to $70 \%$ methanol within $2 \mathrm{~min}, 70 \%$ methanol over $3 \mathrm{~min}$. Step 2 - flow rate: 6 $\mathrm{mL} / \mathrm{min}$; $35 \%$ methanol over $32 \mathrm{~min}, 35 \%$ to $90 \%$ methanol within $2 \mathrm{~min}, 90 \%$ methanol over $1 \mathrm{~min}, 90 \%$ to $35 \%$ methanol within $2 \mathrm{~min}, 35 \%$ methanol over $3 \mathrm{~min}$. The purification yielded $18.9 \mathrm{mg}$ of $7 \mathbf{a}$ and $38.1 \mathrm{mg}$ of $\mathbf{8 a}$. 
7c: Step 1 - flow rate: $6 \mathrm{~mL} / \mathrm{min} ; 50 \%$ methanol over $6 \mathrm{~min}, 50 \%$ to $100 \%$ methanol within $14 \mathrm{~min}, 100 \%$ methanol over $3 \mathrm{~min}$, $100 \%$ to $50 \%$ methanol within $1 \mathrm{~min}, 50 \%$ methanol over $3 \mathrm{~min}$. Step 2 - flow rate: $6 \mathrm{~mL} / \mathrm{min}$; $35 \%$ methanol over $32 \mathrm{~min}$, 35\% to $90 \%$ methanol within $2 \mathrm{~min}, 90 \%$ methanol over $2 \mathrm{~min}, 90 \%$ to $35 \%$ methanol within $1 \mathrm{~min}, 35 \%$ methanol over 3 min. The purification yielded $4.0 \mathrm{mg}$ of $7 \mathrm{c}$.

7d: Step 1 - flow rate: $6 \mathrm{~mL} / \mathrm{min} ; 70 \%$ methanol over $6 \mathrm{~min}, 70 \%$ to $100 \%$ methanol within 9 min, $100 \%$ methanol over 5 min, $100 \%$ to $70 \%$ methanol within $2 \mathrm{~min}, 70 \%$ methanol over $3 \mathrm{~min}$. Step 2 - flow rate: $6 \mathrm{~mL} / \mathrm{min}$; $45 \%$ methanol over $25 \mathrm{~min}$. The purification yielded $9.7 \mathrm{mg}$ of $\mathbf{7 d}$.

7e: Step 1 - flow rate: $6 \mathrm{~mL} / \mathrm{min} ; 70 \%$ methanol over $6 \mathrm{~min}, 70 \%$ to $100 \%$ methanol within 9 min, $100 \%$ methanol over 5 min, $100 \%$ to $70 \%$ methanol within $2 \mathrm{~min}, 70 \%$ methanol over $3 \mathrm{~min}$. Step 2 - flow rate: $6 \mathrm{~mL} / \mathrm{min}$; $45 \%$ methanol over $30 \mathrm{~min}$. The purification yielded $11.1 \mathrm{mg}$ of $7 \mathbf{e}$.

7f: Step 1 - flow rate: $4 \mathrm{~mL} / \mathrm{min} ; 60 \%$ methanol over $5 \mathrm{~min}, 50 \%$ to $100 \%$ methanol within 15 min, $100 \%$ methanol over 2 min, $100 \%$ to $60 \%$ methanol within $2 \mathrm{~min}$, $60 \%$ methanol over $1 \mathrm{~min}$. Step 2 - flow rate: $4 \mathrm{~mL} / \mathrm{min}$; $80 \%$ methanol over $15 \mathrm{~min}$. The purification yielded $7.0 \mathrm{mg}$ of $7 \mathbf{f}$.

Spectroscopic analys es of physostigmine derivatives. The purified compounds 7a, 8a, and 7c-7f were subjected to NMR and high resolution (HR) MS measurements. The NMR measurements were performed with 600 and $700 \mathrm{MHz}$ AVANCE III HD spectrometers (Bruker Biospin $\mathrm{GmbH}$ ). The $600 \mathrm{MHz}$ systemwas equipped with a $5 \mathrm{~mm}$ helium cooled broadband cryoprobe and the $700 \mathrm{MHz}$ system with a $5 \mathrm{~mm}$ helium cooled inverse quadrupol resonance cryoprobe, respectively. The measurements were carried out at ambient temperature. NMR spectra (Table S8-S13, Figure S41-S70) were recorded in chloroform- $d$ or methanol- $d_{4}$ depending on the solubility of the respective compound. The deuterated solvents were also used as internal standards. The chloroform signals were referenced to $\delta_{\mathrm{H}} 7.24 \mathrm{ppm}$ and $\delta_{\mathrm{C}} 77.0 \mathrm{ppm}$, while the methanol signals were referenced to $\delta_{\mathrm{H}} 3.31 \mathrm{ppm}$ and $\delta_{\mathrm{C}}$ 49.0 ppm, respectively. HRMS measurement were conducted on an Agilent 1260 Infinity HPLC system combined with a Bruker Daltonics Compact quadrupole time of flight mass spectrometer. The analyses were run in positive mode. HPLC flow rate was 0.4 $\mathrm{mL} / \mathrm{min}$ on a Nucleoshell RP 18 ec column $(100 \times 2 \mathrm{~mm}, 2.7 \mu \mathrm{m}$; Macherey-Nagel) and a gradient from 5 to $98 \%$ acetonitrile in water supplemented with $0.1 \%$ formic acid over $10 \mathrm{~min}$, followed by $5 \mathrm{~min}$ at $98 \%$ acetonitrile. All analyses were carried out at a capillary voltage of $4.5 \mathrm{kV}$, desolvation gas $\left(\mathrm{N}_{2}\right)$ temperature of $220{ }^{\circ} \mathrm{C}$, with a dry gas $\left(\mathrm{N}_{2}\right)$ flow rate of $12 \mathrm{~L} / \mathrm{min}$. The results of the HRMS measurements are listed below:

Ethyl-physostigmine (7a): HRESIMS $m / z 290.1867$ (calcd for $\mathrm{C}_{16} \mathrm{H}_{24} \mathrm{~N}_{3} \mathrm{O}_{2}, 290.1863$ )

8-Desmethyl-ethyl-physostigmine (8a): HRESIMS $m / z$ 276.1701 (calcd for $\mathrm{C}_{15} \mathrm{H}_{22} \mathrm{~N}_{3} \mathrm{O}_{2}, 276.1707$ )

Fluorophysostigmine (7c): HRESIMS $m / z 221.1445$ (calcd for $\mathrm{C}_{13} \mathrm{H}_{18} \mathrm{FN}_{2}, 221.1449$ )

Chlorophysostigmine (7d): HRESIMS $m / z 237.1153$ (calcd for $\mathrm{C}_{13} \mathrm{H}_{18} \mathrm{ClN}_{2}, 237.1153$ )

Bromophysostigmine (7e): HRESIMS $m / z 281.0647$ (calcd for $\mathrm{C}_{13} \mathrm{H}_{18} \mathrm{BrN}_{2}, 281.0648$ )

n-Butanoylated intermediate (7f): HRESIMS $m / z$ 318.1806 (calcd for $\mathrm{C}_{17} \mathrm{H}_{24} \mathrm{~N}_{3} \mathrm{O}_{3}, 318.1812$ )

Antiprotozoal activity assay. The compounds $\mathbf{7 a}$ and $\mathbf{7 c - f}$ were tested against the parasites Trypanosoma brucei rhodesiense (strain STIB 900) trypomastigotes, Trypanosoma cruzi (strai Tulahuen C4) amastigotes, Leishmania donovani (strain MHOMET-67/L82) amastigotes and Plasmodium falciparum (strain NF54, stage IEF). The antiprotozoal activity data were compared to the reference drugs melarsoprol, benznidazole, miltefosine or chloroquine. Cytotoxic effects were analyzed using L6 cells (rat myoblast) and podophyllotoxin as reference drug. The assay was performed in 96-well plates using varied concentrations of 7a and $7 \mathbf{c - f}$ to calculate $\mathrm{IC}_{50}$ values. Each assay was performed in duplicates according to a previously published protocol. ${ }^{11}$

Cholinesterase inhibition as s ay. Inhibitory activity of AChE (from Electrophorus electricus) and BChE (from equine serum) was determined by using the Ellman method as previously described. ${ }^{12,13}$ As references, rivastigmine (TCI Deutschland GmbH, Eschborn, Germany) and physostigmine (EDQM, Strasbourg, France) were used. All compounds were directly dissolved in DMSO to give a $125 \mathrm{mM}$ stock solution and then further diluted with $100 \mathrm{mM}$ potassium phosphate buffer (KPi) pH 8 to give the desired dilution using 96-well-plates (Greiner, Item No.: 655101). 1:4 dilution series were made for each compound to obtain twelve concentrations ranging from $31 \mathrm{mM}$ to $7 \mathrm{nM}$. Each concentration was tested in three replicates. A total of $162 \mu \mathrm{L}$ of $1.5 \mathrm{mM}$ DNTB solution (dis solved in $100 \mathrm{mM} \mathrm{KPi} \mathrm{pH} \mathrm{8)} \mathrm{was} \mathrm{first} \mathrm{added} \mathrm{to} \mathrm{each} \mathrm{well.} \mathrm{Second,} 8 \mu \mathrm{L}$ of each tested compound solution was added to each well except for the positive control, for which $8 \mu \mathrm{L} 25 \%$ DMSO was used. Third, $50 \mu \mathrm{L}$ of AChE enzyme solution (0.5 
$\mathrm{U} / \mathrm{mL}$ dissolved in $100 \mathrm{mM} \mathrm{KPi} \mathrm{pH} \mathrm{8,} \mathrm{activity} \mathrm{according} \mathrm{to} \mathrm{the} \mathrm{supplier's} \mathrm{instructions)} \mathrm{or} \mathrm{BChE} \mathrm{enzyme} \mathrm{solution} \mathrm{(5} \mathrm{U/mL} \mathrm{dis-}$ solved in $100 \mathrm{mM} \mathrm{KPi} \mathrm{pH} \mathrm{8,} \mathrm{activity} \mathrm{according} \mathrm{to} \mathrm{the} \mathrm{supplier's} \mathrm{instructions)} \mathrm{was} \mathrm{added} \mathrm{to} \mathrm{each} \mathrm{well,} \mathrm{except} \mathrm{for} \mathrm{the} \mathrm{blank} \mathrm{row.}$ Following a $10 \mathrm{~min}$ preincubation at $23{ }^{\circ} \mathrm{C}, 30 \mu \mathrm{L}$ acetylthiocholine iodide solution (15 mM, dissolved in $\left.100 \mathrm{mM} \mathrm{KPi} \mathrm{pH} 8\right)$ was added to each well to start the assay. After a $5 \mathrm{~s}$ linear shake, the absorbance at $410 \mathrm{~nm}$ was measured for 5 min every $30 \mathrm{~s}$ using a Tecan Infinite M1000Pro microplate reader. The results are reported as mean- \pm standard deviation. The inhibition properties are reported as $\mathrm{IC}_{50}$ values, which were determined graphically by using OriginPro 2019 (OriginLab Corporation, Northampton, MA). $\mathrm{IC}_{50}$ values represent the concentration of inhibitor required for the inhibition of $50 \%$ of the AChE activity. 
Table S2. Bacterial strains and plasmids used in this study

\begin{tabular}{|c|c|c|}
\hline Strain or plas mid & Specification & Source or reference \\
\hline E. coli $\mathrm{DH} 5 \alpha$ & $\begin{array}{l}\mathrm{F}^{-} \varphi 80 \text { lacZ } \Delta \mathrm{M} 15 \Delta(\text { lacZYA-argF }) \mathrm{U} 169 \text { recA } 1 \text { endA } 1 \\
h s d \mathrm{R} 17\left(\mathrm{r}^{-}, \mathrm{mK}^{+}\right) \text {phoA supE44 } \lambda^{-} \text {thi-1 gyrA96 relA } 1\end{array}$ & Thermo Fisher Scientific \\
\hline E. coli TOP10 & $\begin{array}{l}\mathrm{F}^{-} \text {mcrA } \Delta(\text { mrr-hsd } \mathrm{RMS}-m c r \mathrm{BC}) \quad \varphi 80 \text { lac } \mathrm{Z} \Delta \mathrm{M} 15 \Delta \text { lacX74 } \\
\left.\text { rec } \mathrm{A} 1 \text { ara } \mathrm{D} 139 \Delta(\text { ara-leu }) 7697 \text { gal } \mathrm{Ual \textrm {K }} \lambda^{-} \text {rpsL(} \mathrm{Str}^{\mathrm{R}}\right) \\
\text { end } \mathrm{A} 1 \text { nup } \mathrm{G}\end{array}$ & Thermo Fisher Scientific \\
\hline M. xanthus FB & type strain of $M$. xanthus & $\begin{array}{l}\text { DSMZ (DSM 16526); } \\
\text { Dworkin \& Sadler, } 1966\end{array}$ \\
\hline M. xanthus NM & nonmotile mutant of $M$. xanthus FB & $\begin{array}{l}\text { ATCC (ATCC 27925); } \\
\text { Burchard, } 1970\end{array}$ \\
\hline pUC57-psmA-F & vector with synthetic genes $p s m A-F$ & ATG:biosynthetics \\
\hline pZJY156 & derivative of pMF1 & Zhao et al., 2008 \\
\hline pSK01 & derivative of pZJY156 ( $\Delta a m p)$ & This study \\
\hline pMEX01 & derivative of pSK01 ( $\left.\mathrm{T}_{m l p A}, \mathrm{MCS}_{\text {extended }}\right)$ & This study \\
\hline pMEX02 & pMEX01 carrying the $\mathrm{P}_{\text {pila }}$ promoter region & This study \\
\hline pMEX03 & pMEX01 carrying $\mathrm{P}_{\text {pila, fus }}$ fusion promoter region & This study \\
\hline pMEX04 & pMEX01 carrying $\mathrm{P}_{\text {pilA }}$ and $p s m A-F$ & This study \\
\hline pMEX05 & pMEX01 carrying $\mathrm{P}_{\text {pila,fus }}$-psmD & This study \\
\hline pMEX06 & pMEX01 carrying $\mathrm{P}_{\text {pila,fus }}$ psmC & This study \\
\hline pMEX07 & pMEX01 carrying $\mathrm{P}_{\text {pila }}$ and $p s m D$ & This study \\
\hline pMEX08 & pMEX01 carrying $\mathrm{P}_{\text {pila,fus }}-p s m D$ and $\mathrm{P}_{\text {pilA,fus }}-p s m C$ & This study \\
\hline pMEX09 & pMEX01 carrying $\mathrm{P}_{\text {pila,fus }}$-psmB & This study \\
\hline pMEX10 & $\begin{array}{l}\text { pMEX01 carrying } \mathrm{P}_{\text {pila, fus }}-p s m D, \mathrm{P}_{\text {pilA,fus }}-p s m C \text { and } \mathrm{P}_{\text {pilA, fus }} \\
\text { psmB }\end{array}$ & This study \\
\hline
\end{tabular}


Table S3. Oligonucleotides used in this study

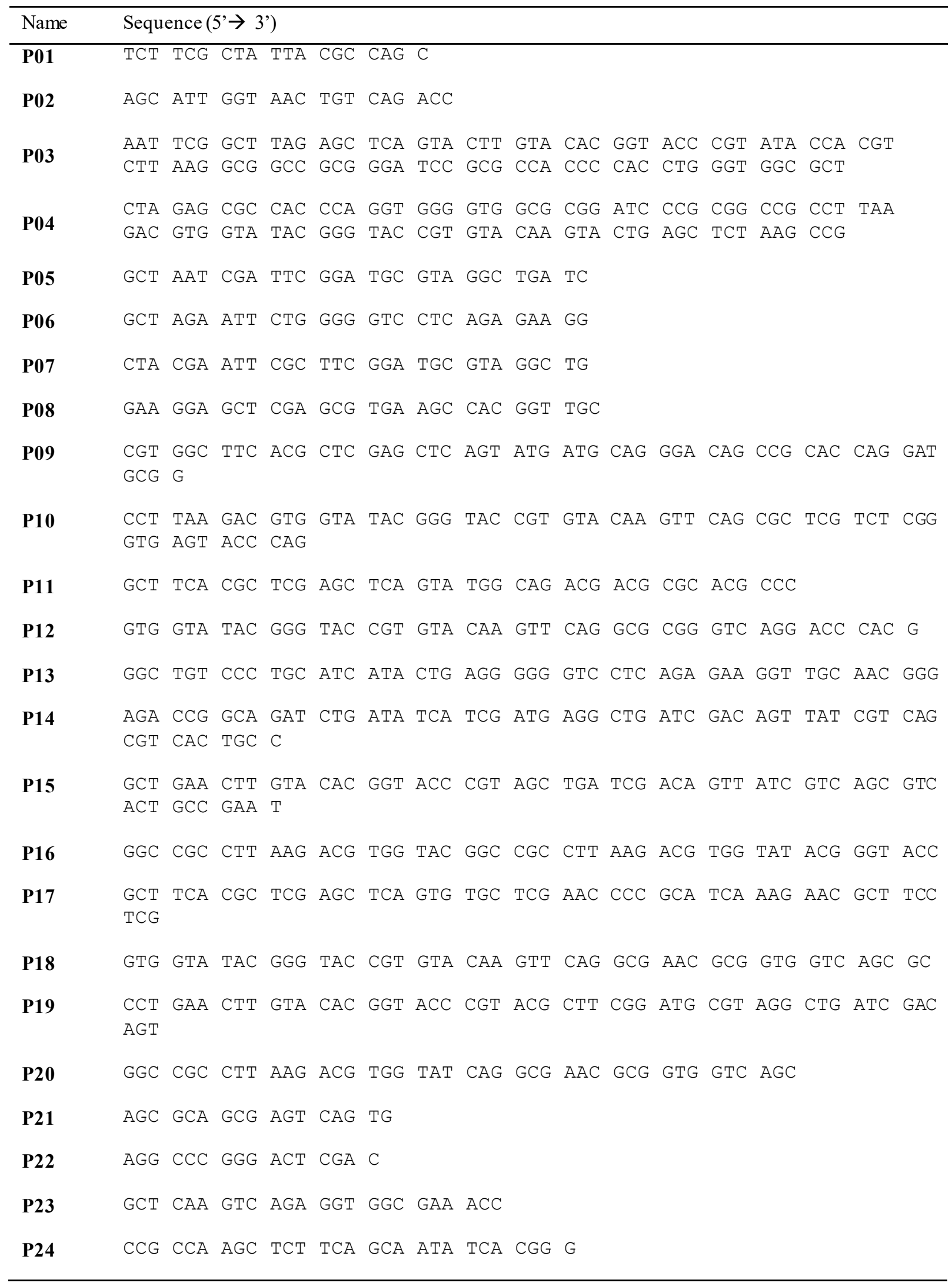



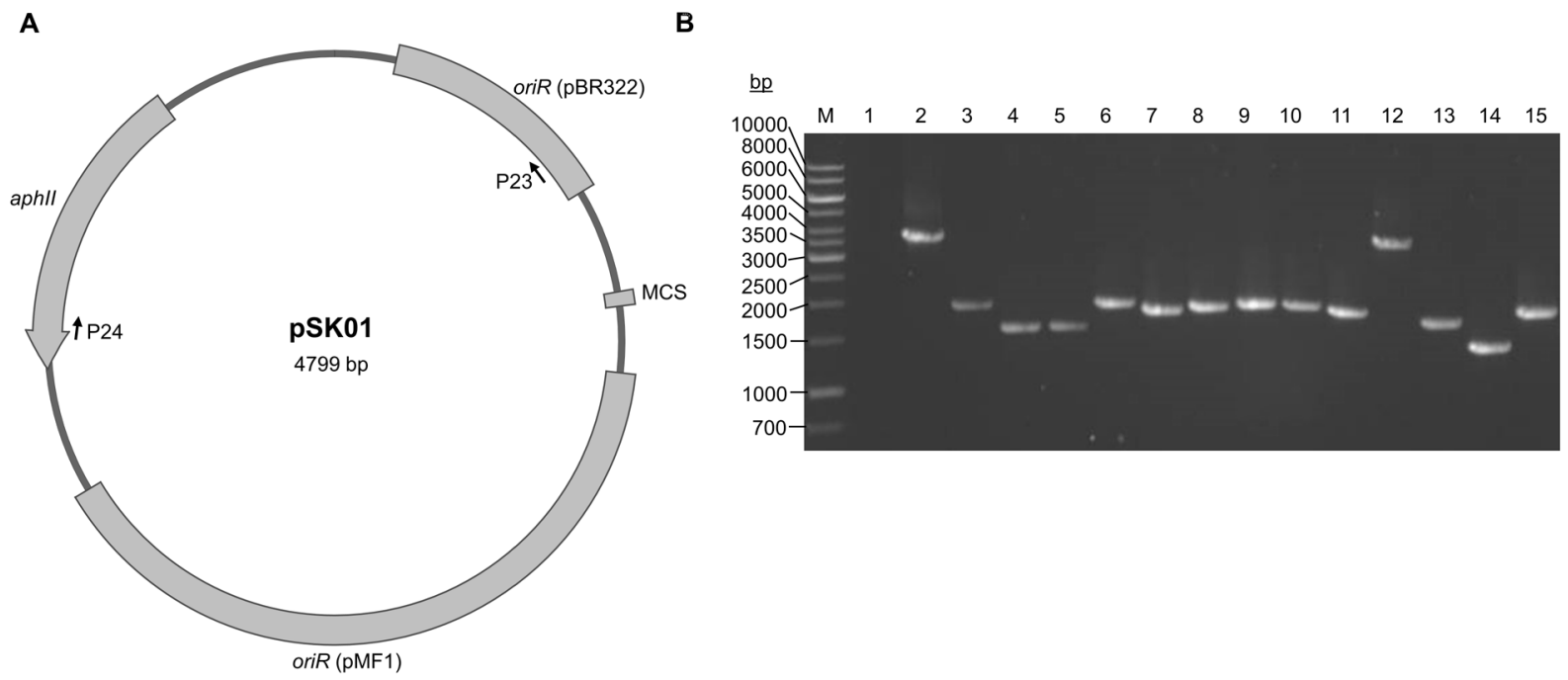

Figure S2. Schematic map of the myxobacterial expresssion plasmid pSK01 (A). Validation of pSK01 by colony PCR using the primers P23/P24 (B). 1: negative control. 2: pZJY156. 3-15: E. coli DH5a:pSK01 clone 1-13. Expected PCR product: 1905 bp. M: DNA ladder.

A

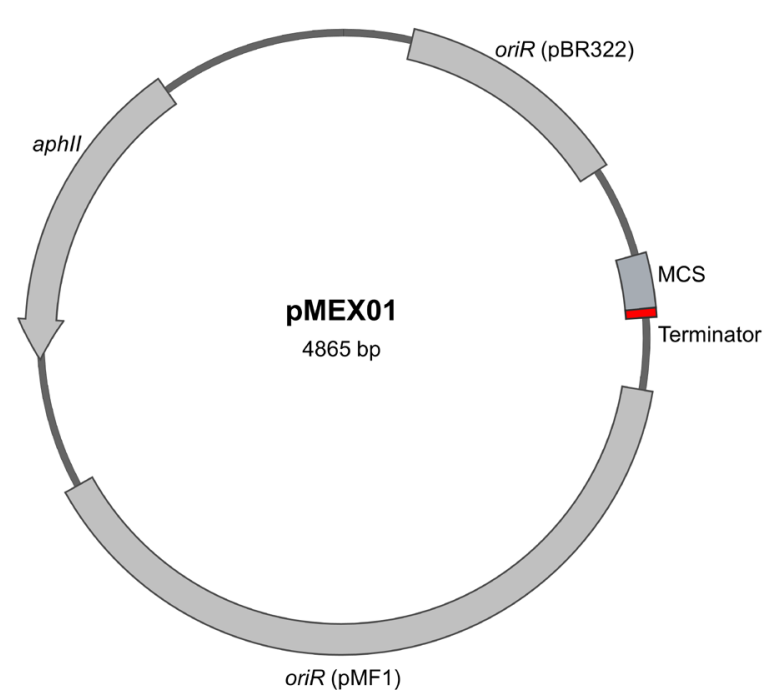

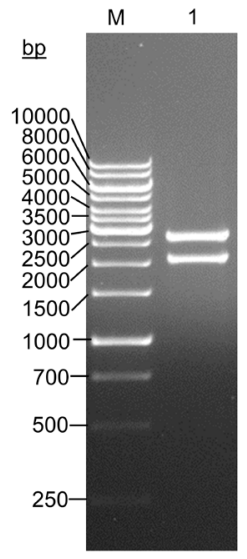

Figure S3. Schematic map of the myxobacterial expression plasmid pMEX01 (A). Restriction analysis of pMEX01 (B). 1: NcoI\&ScaI (2137 bp, 2738 bp). M: DNA ladder. 
A

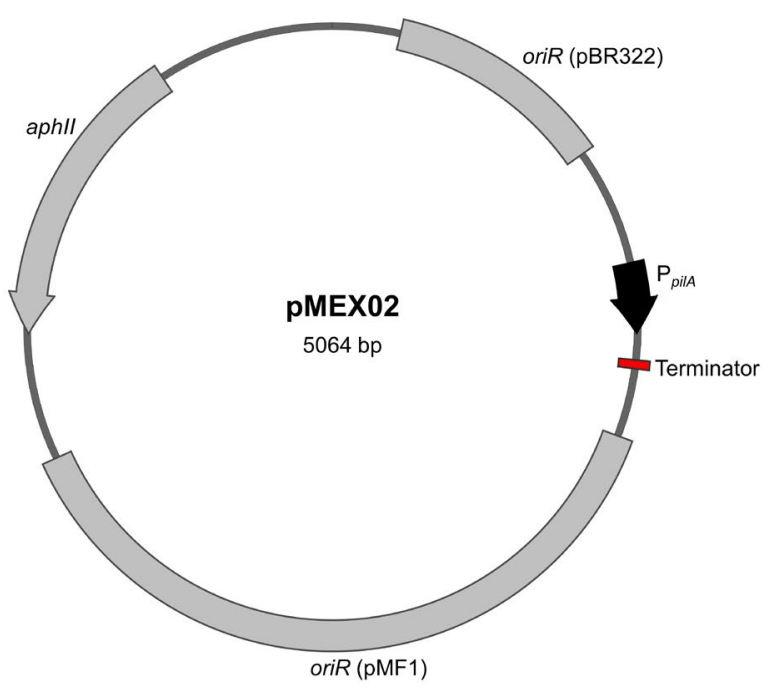

B

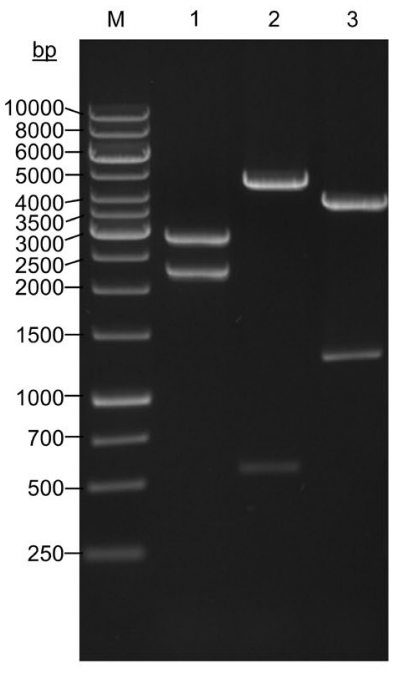

Figure S4. Schematic map of the myxobacterial expression plasmid pMEX02, harboring the promoter region $\mathrm{P}_{\text {pila }}$ (A). Restriction analysis of pMEX02 (B). 1: SalI (2214 bp, 2850 bp), 2: MluI\&ClaI (542 bp, 4522 bp), 3: EcoRV (1237 bp, 3827 bp). M: DNA ladder.

A

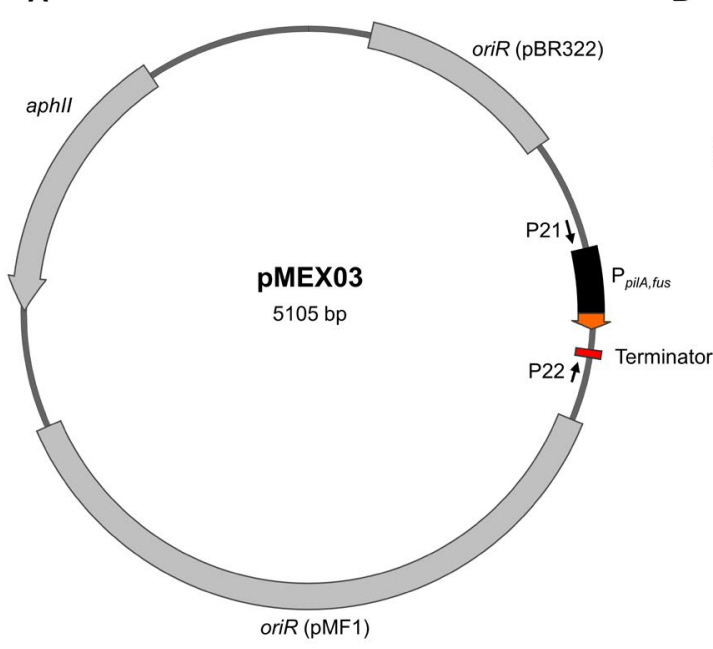

B

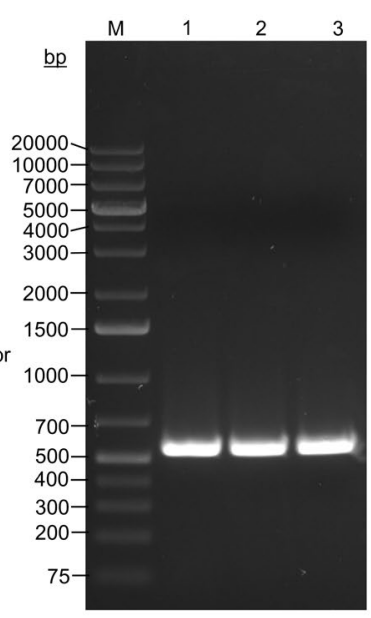

C

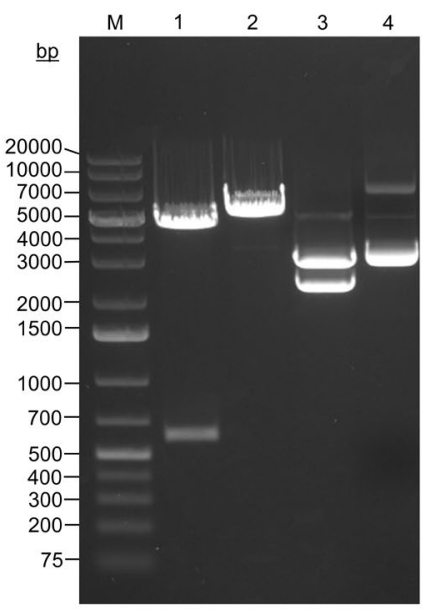

Figure S5. Schematic map of the myxobacterial expression plasmid pMEX03, harboring $\mathrm{P}_{\text {pila,fus }}$ (A). Validation of pMEX03 by colony PCR using the primers P21/P22. 1-3: E. coli TOP10:pMEX03 clone 1-3. Expected PCR product: 542 bp (B). Restriction analys is of pMEX03 (C). 1: MluI\&EcoRI (578 bp, 4527 bp), 2: XagI (5105 bp), 3: SalI (2891 bp), 4: undigested plasmid. M: DNA ladder. 
A

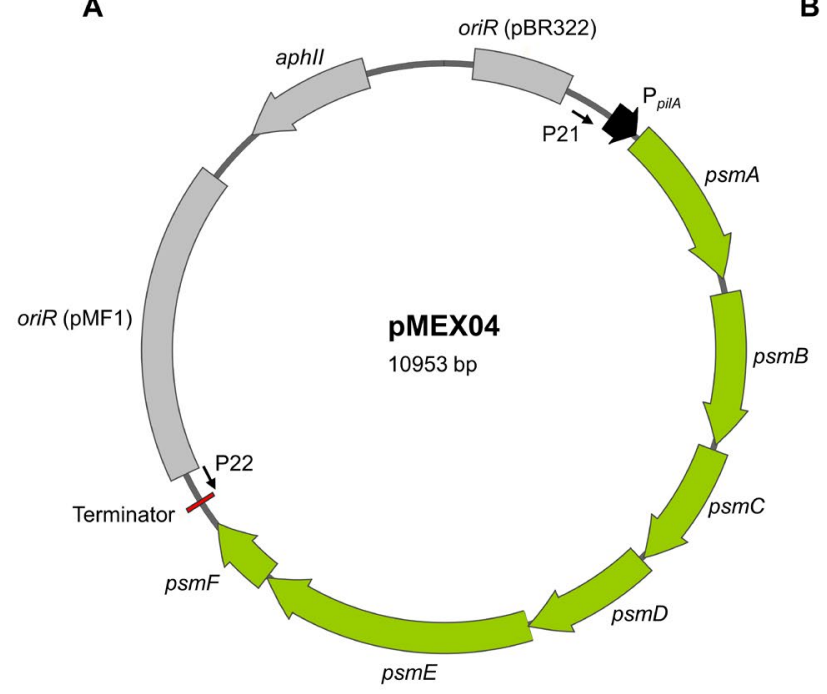

B

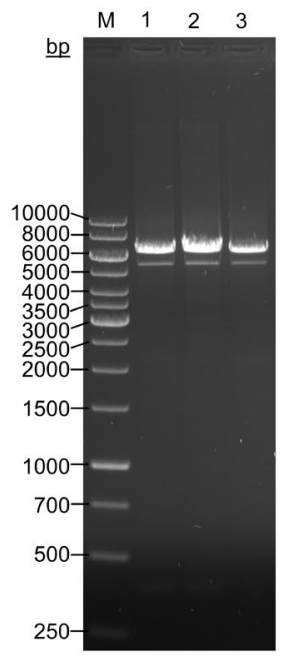

C

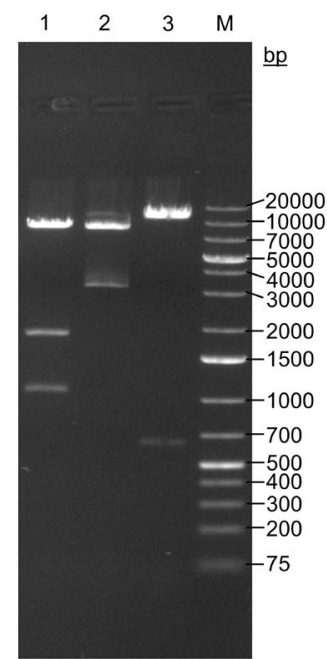

Figure S6. Schematic map of the myxobacterial expression plasmid pMEX04, harboring $\mathrm{P}_{p i l A}$ and the physostigmine biosynthesis genes $\operatorname{sim} A-F$ (A). Validation of pMEX04 by colony PCR using the primers P21/P22. 1-3: E. coli DH5a:pMEX04 clone 1-3. Expected PCR product: 6390 bp (B). Restriction analysis of pMEX04 (C). 1: DraIII (1032 bp, 1789 bp, 8132 bp), 2: PstI (3050 bp, 7903 bp), 3: XbaI, PdmI (621 bp, 10332 bp). M: DNA ladder.

A

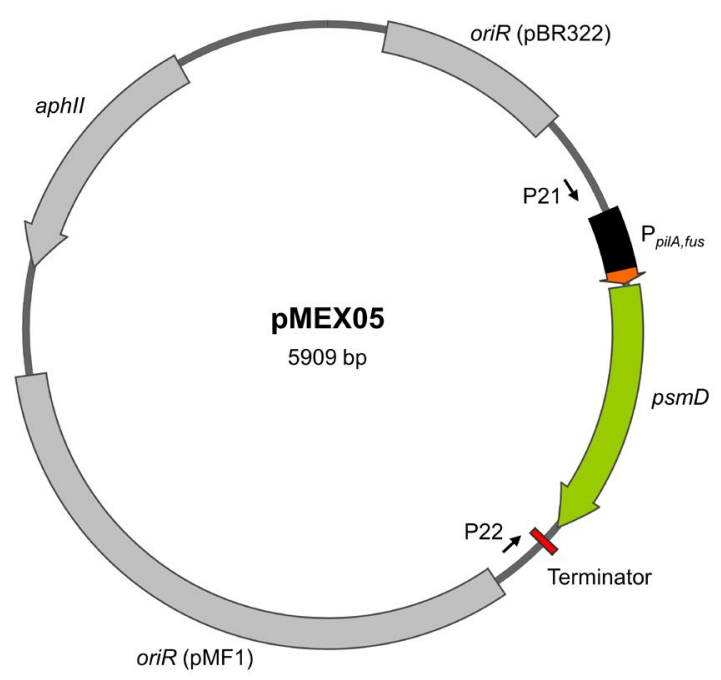

B

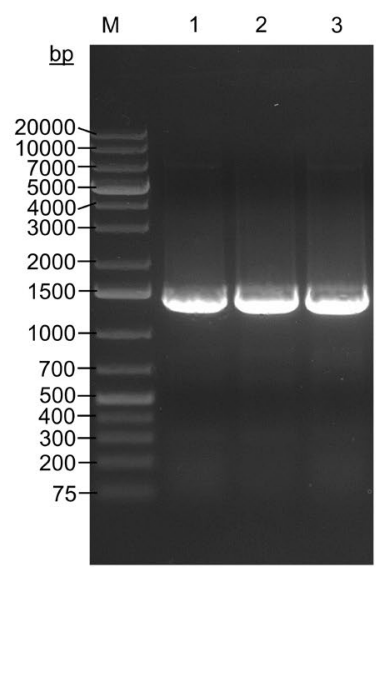

C

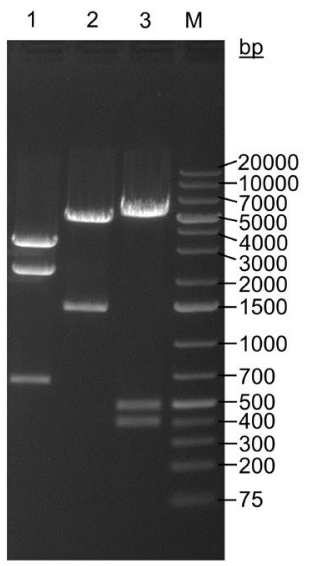

Figure S7. Schematic map of the myxobacterial expression plasmid pMEX05, harboring $\mathrm{P}_{\text {pilA, fus }}$ and the physostigmine biosynthesis gene $\operatorname{sinD}(\mathbf{A})$. Validation of pMEX05 by colony PCR using the primers P21/P22. 1-3: E. coli TOP10:pMEX05 clone 1-3. Expected PCR product: 1346 bp (B). Restriction analysis of pMEX05 (C). 1: BoxI\&EcoNI (636 bp, 2131 bp, 3142 bp), 2: MluI\&EcoRI (1382 bp, 4527 bp), 3: NotI\&SacI (375 bp, 469 bp, 5065 bp). M: DNA ladder. 
A

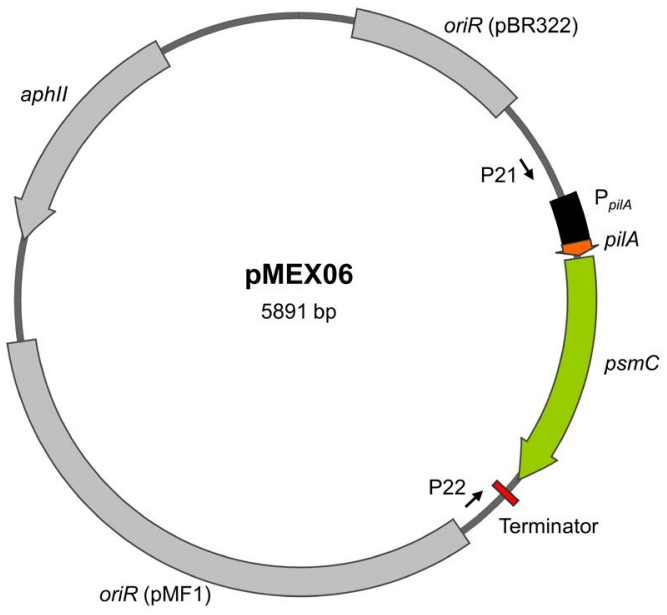

B

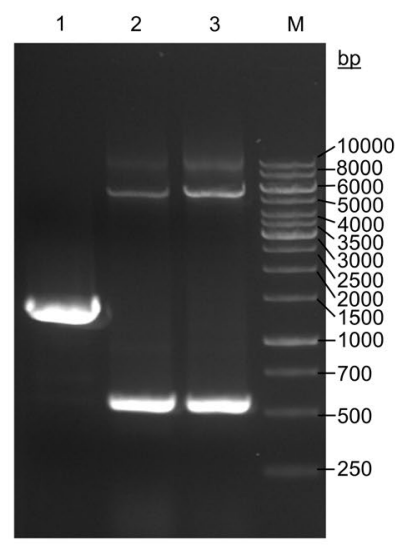

C

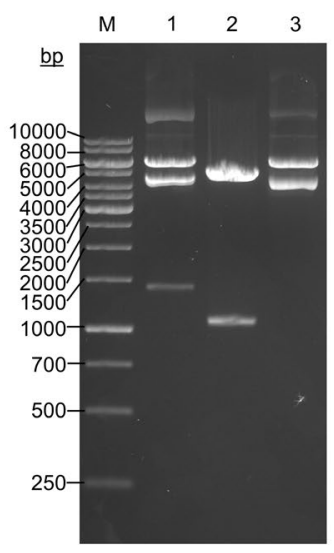

Figure S8. Schematic map of the myxobacterial expression plasmid pMEX06, harboring $\mathrm{P}_{\text {pila, fus }}$ and the physostigmine biosynthesis gene $p s m C$ (A). Validation of pMEX06 by colony PCR using the primers P21/P22. 1-3: E. coli TOP10:pMEX06 clone 1-3. Expected PCR product: 1328 bp (B). Restriction analysis of pMEX06 (C). 1: AatII (1386 bp, 4505 bp), 2: KpnI\&Bsu15I (1066 bp, 4825 bp), 3: MluI (5891 bp). M: DNA ladder.

A

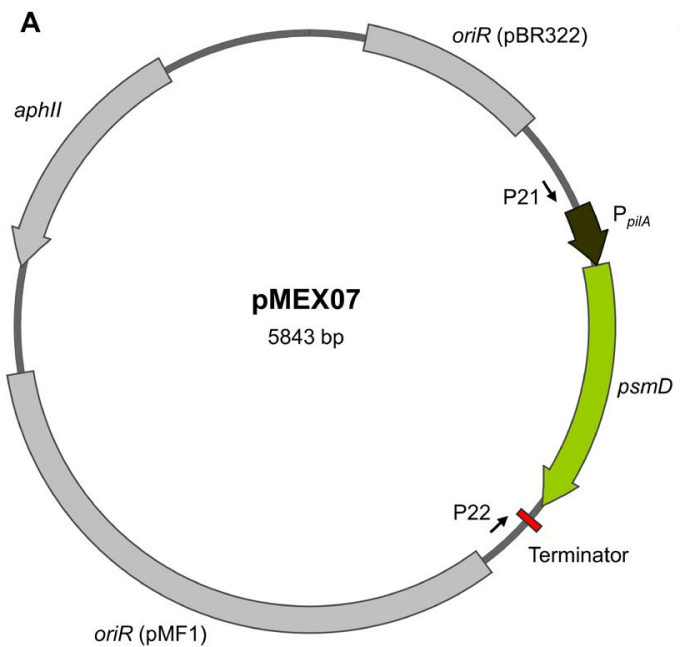

B

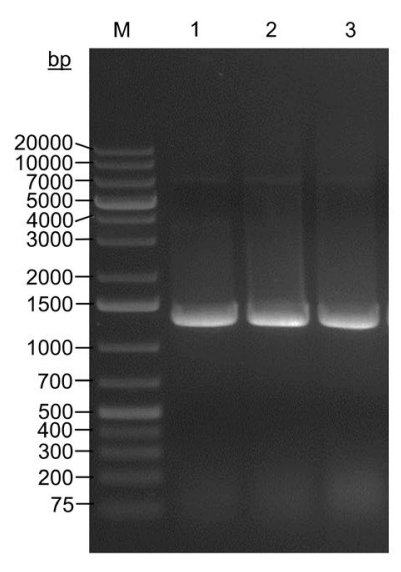

C

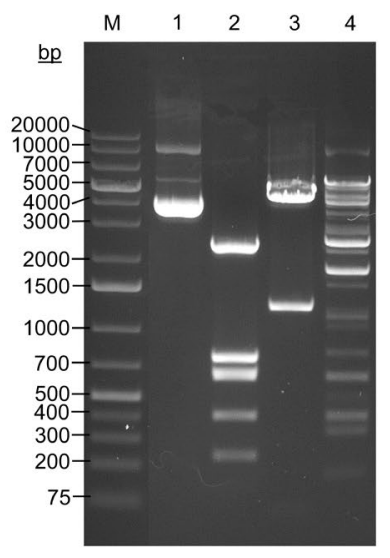

Figure S9. Schematic map of the myxobacterial expression plasmid pMEX07, harboring $\mathrm{P}_{\text {pilA }}$ and the physostigmine biosynthesis gene psmD (A). Validation of pMEX07 by colony PCR using the primers P21/P22. 1-3: E. coli TOP10:pMEX07 clone 1-3. Expected PCR product: $1280 \mathrm{bp}(\mathbf{B})$. Restriction analys is of pMEX07 (C). 1: undigested plasmid, 2: Eco47I (235 bp, 413 bp, 629 bp, 660 bp, 757 bp, 768 bp, 2381 bp), 3: HindIII (39 bp, 1257 bp, 4547 bp), 4: HindII (171 bp, 340 bp, 409 bp, 633 bp, 1805 bp, 2485 bp). M: DNA ladder. 
A

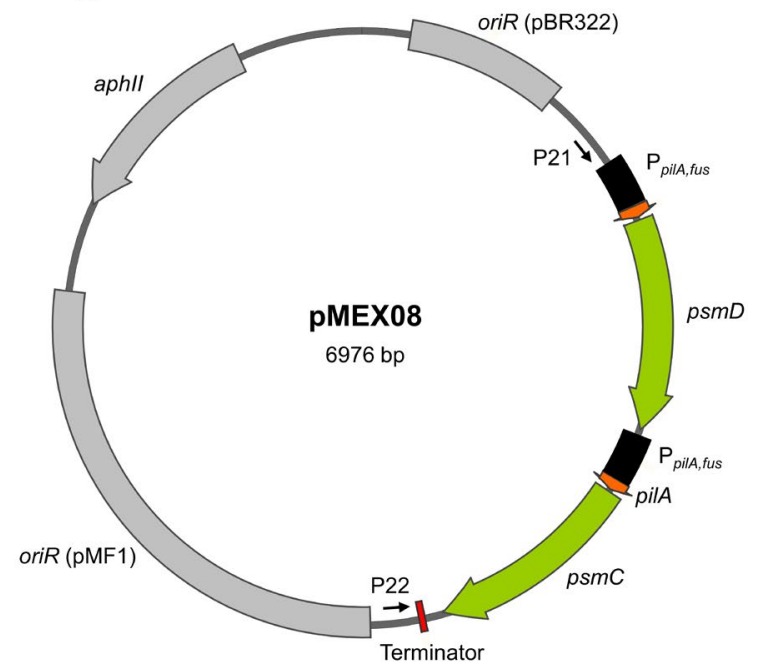

B

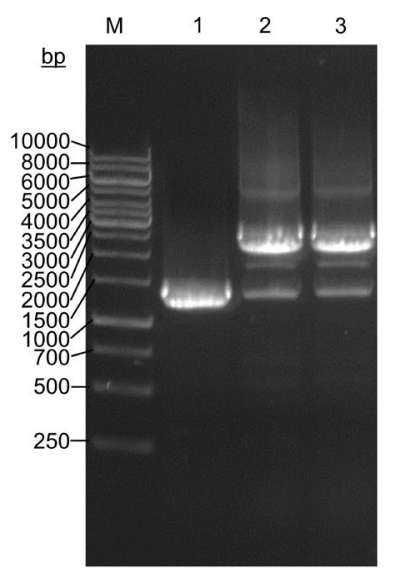

C

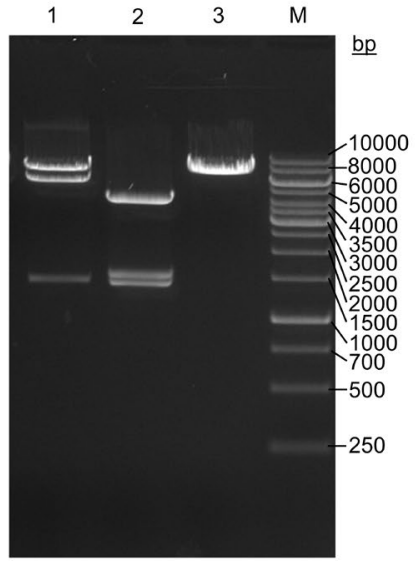

Figure S10. Schematic map of the myxobacterial expression plasmid pMEX08, harboring $\mathrm{P}_{\text {pilA,fus }}$ and the physostigmine biosynthes is genes $p s m D$ and $p s m C$ (A). Validation of pMEX08 by colony PCR using the primers P21/P22. 1-3: E. coli TOP10:pMEX08 clone 1-3. Expected PCR product: 2413 bp (B). Restriction analysis of pMEX08 (C). 1: AatII (1407 bp, 5569 bp), 2: BglII (1386 bp, 1503 bp, 4087 bp), 3: PmlI (6976 bp). M: DNA ladder.

A

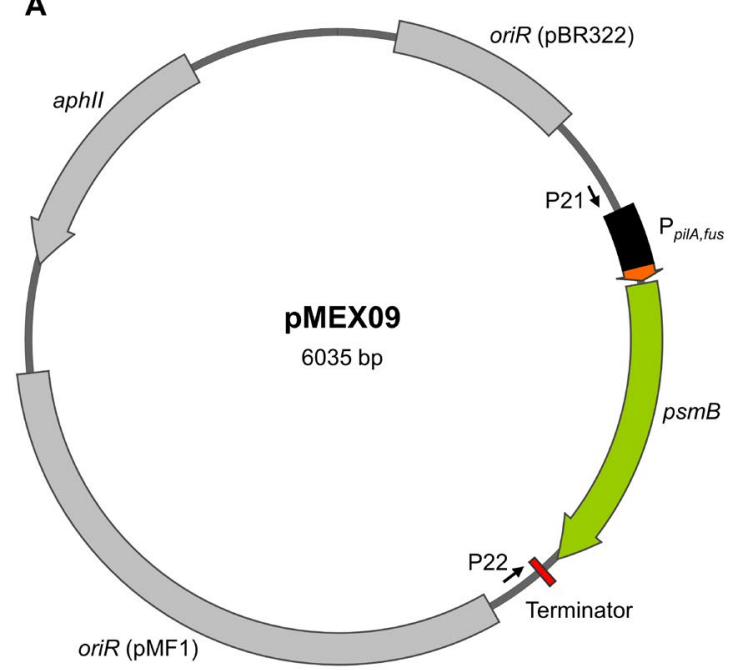

B

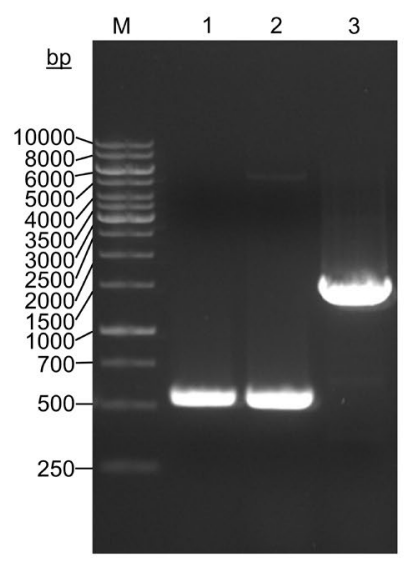

C

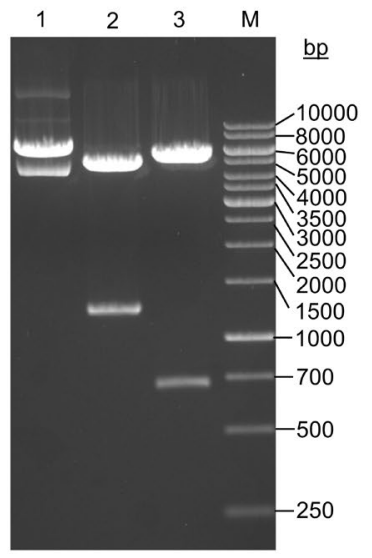

Figure S11. Schematic map of the myxobacterial expression plasmid pMEX09, harboring $\mathrm{P}_{\text {pila,fus }}$ and the physostigmine biosynthes is gene $\operatorname{smB}(\mathbf{A})$. Validation of pMEX09 by colony PCR using the primers P21/P22. 1-3: E. coli TOP10:pMEX09 clone 1-3. Expected PCR product: 1472 bp (B). Restriction analysis of pMEX09 (C). 1: MluI (6035 bp), 2: KpnI\&Bsu15I (1210 bp, 4825 bp), 3: BamHI (698 bp, 5337 bp). M: DNA ladder. 


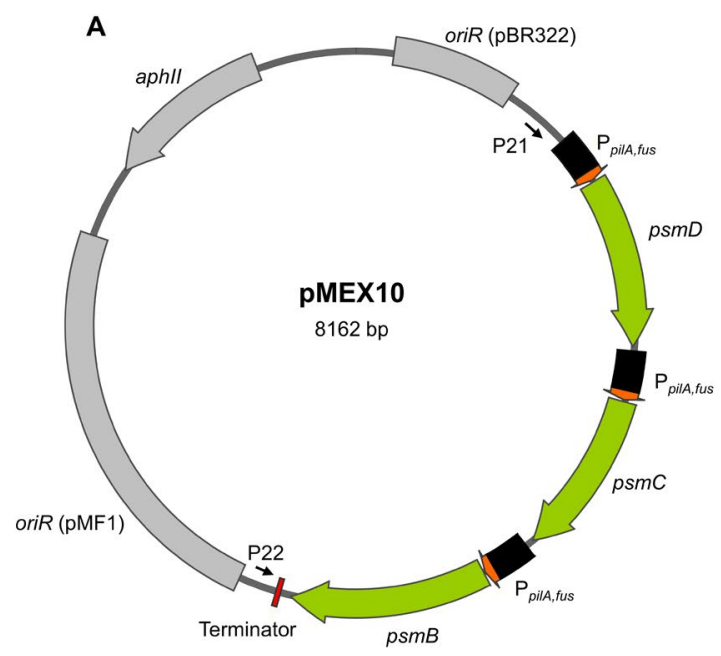

B

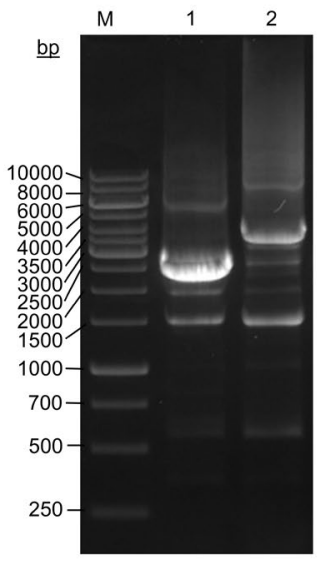

C

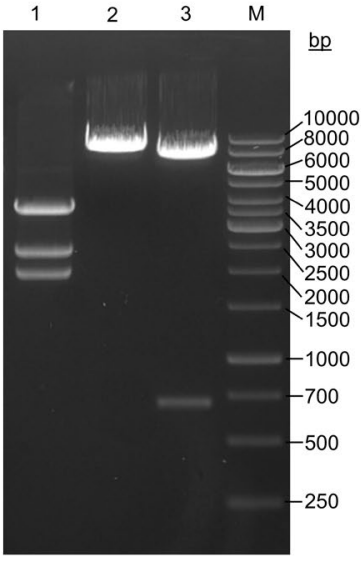

Figure S12. Schematic map of the myxobacterial expression plasmid pMEX10, harboring $\mathrm{P}_{\text {pila, fus }}$ and the physostigmine biosynthesis genes $p s m D, p s m C$, and $\operatorname{psmB}(\mathbf{A})$. Validation of pMEX10 by colony PCR using the primers P21/P22. 1-2: E. coli TOP10:pMEX10 clone 1 and 2. Expected PCR product:3599 bp (B). Restriction analysis of pMEX10 (C). 1: BoxI (1985 bp, 2399 bp, 3778 bp), 2: MluI (8162 bp), 3: BamHI (699 bp, 7463 bp). M: DNA ladder. 

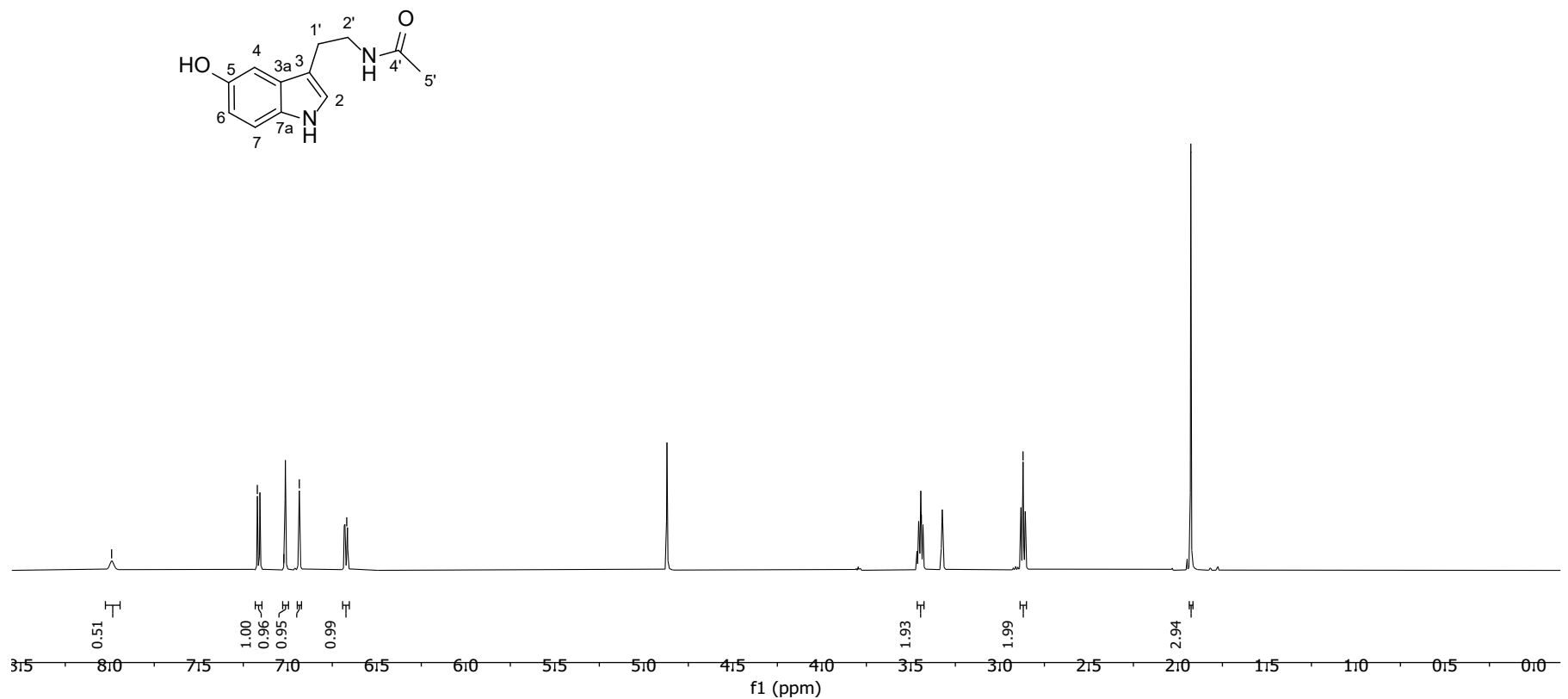

Figure S13. ${ }^{1} \mathrm{H}$ NMR spectrum $(600 \mathrm{MHz})$ of $N$-acetylserotonin $(2)$ in methanol- $d_{4} . \delta[\mathrm{ppm}]=7.99(\mathrm{~s}, 1 \mathrm{H}, 1-\mathrm{H}), 7.17\left(\mathrm{~d}, 1 \mathrm{H}, \quad{ }^{3} \mathrm{~J}_{7,6}\right.$ $=8.6 \mathrm{~Hz}, 7-\mathrm{H}), 7.02(\mathrm{~s}, 1 \mathrm{H}, 2-\mathrm{H}), 6.94\left(\mathrm{~d}, 1 \mathrm{H}{ }^{4} \mathrm{~J}_{4,6}=2.3 \mathrm{~Hz}, 4-\mathrm{H}\right), 6.67\left(\mathrm{dd}, 1 \mathrm{H},{ }^{3} \mathrm{~J}_{6,7}=8.6 \mathrm{~Hz},{ }^{4} \mathrm{~J}_{6,4}=2.3 \mathrm{~Hz}, 6-\mathrm{H}\right), 3.44(\mathrm{t}, 2 \mathrm{H}$, $\left.{ }^{3} \mathrm{~J}_{2}{ }^{,}, 1^{\prime}=7.3 \mathrm{~Hz}, 2^{\prime}-\mathrm{H}\right), 2.87$ (t, 2H, $\left.{ }^{3} \mathrm{~J}_{1^{\prime}, 2^{\prime}}=7.3 \mathrm{~Hz}, 1^{\prime}-\mathrm{H}\right), 1.93$ (s, 3H, 5'-H). Data was assigned by 2D NMR analysis. 

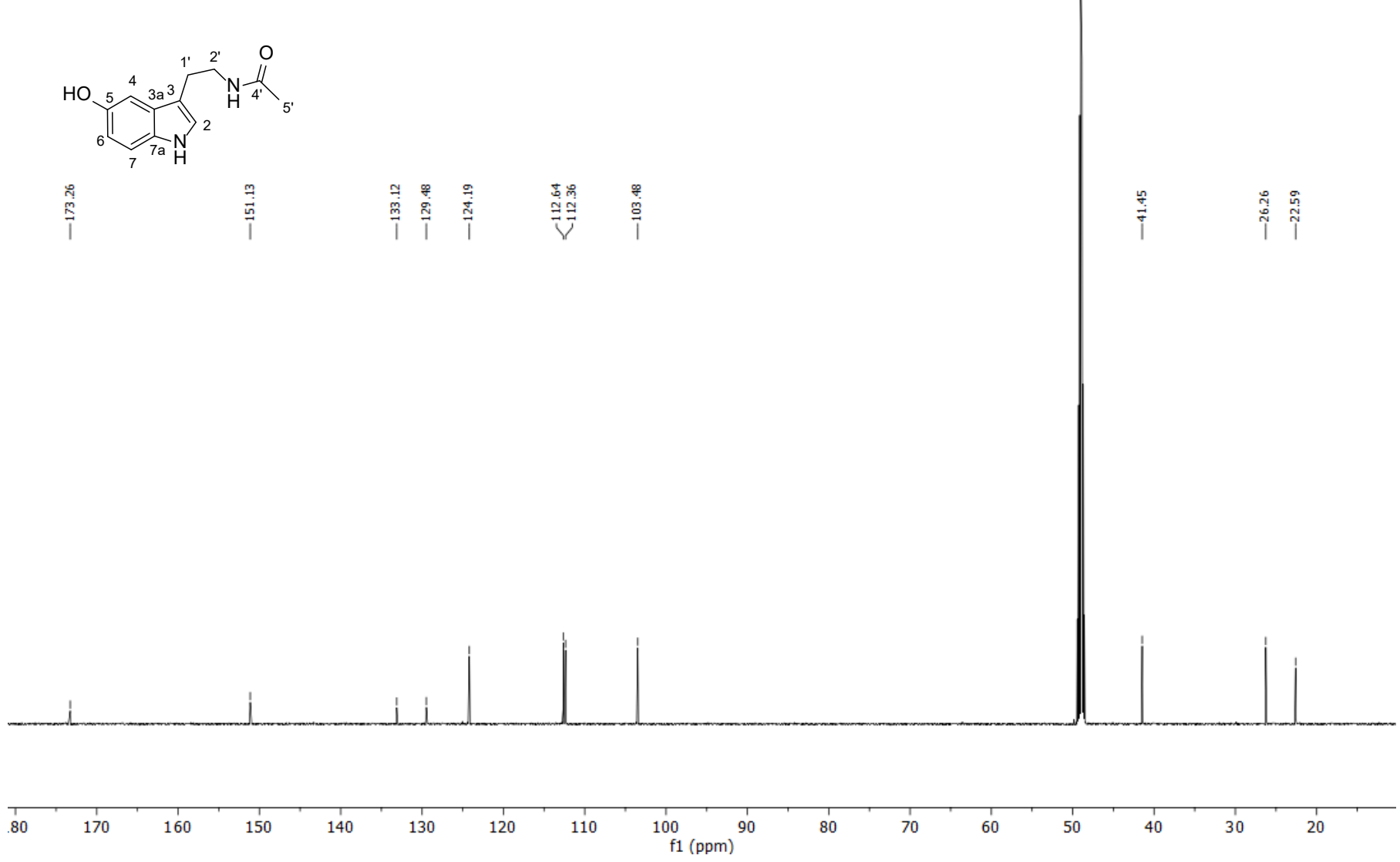

Figure S14. ${ }^{13} \mathrm{C}$ NMR spectrum $(150 \mathrm{MHz})$ of $N$-acetylserotonin (2) in methanol- $d_{4} . \delta[\mathrm{ppm}]=173.3(\mathrm{C}-4$ '), $151.1(\mathrm{C}-5), 133.0$ (C-7a), 129.5 (C-3a), 124.2 (C-2), 117.2 (C-3), 112. 7 (C-4), 112.4 (C-7), 103.5 (C-6), 41.3 (C-2'), 26.3 (C-1') , 23.0 (C-5'). 


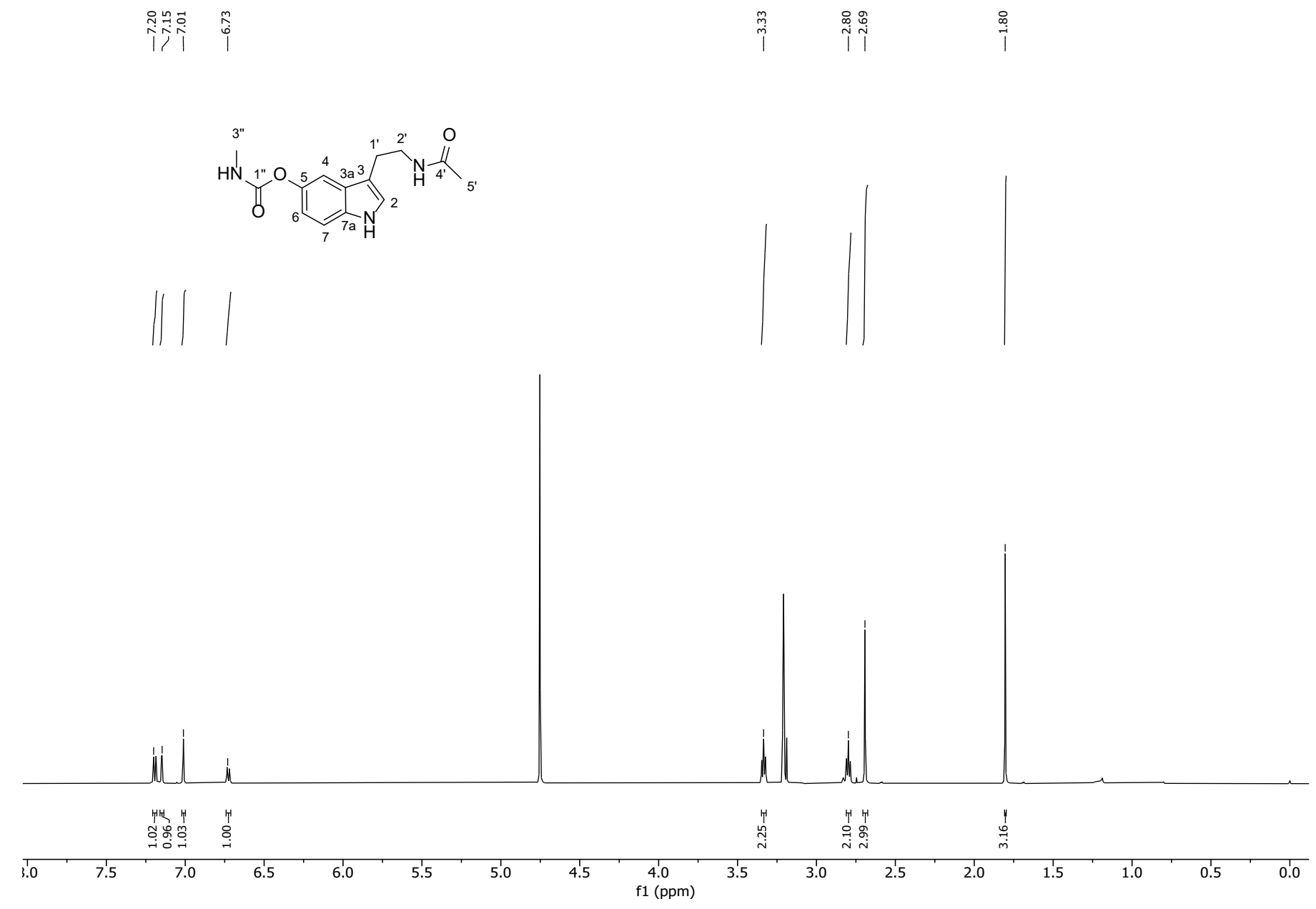

Figure S15. ${ }^{1} \mathrm{H}$ NMR spectrum $(600 \mathrm{MHz})$ of 5-O-methyl-carbamoyl- $N$-acetyls erotonin $(3)$ in methanol- $d 4 . \delta[\mathrm{ppm}]=7.20(\mathrm{~d}, 1 \mathrm{H}$, $\left.{ }^{3} \mathrm{~J}_{7,6}=8.6 \mathrm{~Hz}, 7-\mathrm{H}\right), 7.15(\mathrm{~s}, 1 \mathrm{H}, 2-\mathrm{H}), 7.01(\mathrm{~s}, 1 \mathrm{H}, 4-\mathrm{H}), 6.73\left(\mathrm{~d}, 1 \mathrm{H},{ }^{3} \mathrm{~J}_{6,7}=8.6 \mathrm{~Hz}, 6-\mathrm{H}\right), 3.33\left(\mathrm{t}, 2 \mathrm{H},{ }^{3} \mathrm{~J}_{2}{ }^{\prime}, 1^{\prime}=7.3 \mathrm{~Hz}, 2^{\prime}-\mathrm{H}\right), 2.80$ $\left(\mathrm{t}, 2 \mathrm{H},{ }^{3} \mathrm{~J}_{1}, 2^{\prime}=7.3 \mathrm{~Hz}, 1\right.$ '-H), $2.69(\mathrm{~s}, 3 \mathrm{H}, 3$ ''-H) $1.80(\mathrm{~s}, 3 \mathrm{H}, 5$ '-H). Data was assigned by 2D NMR analysis. 

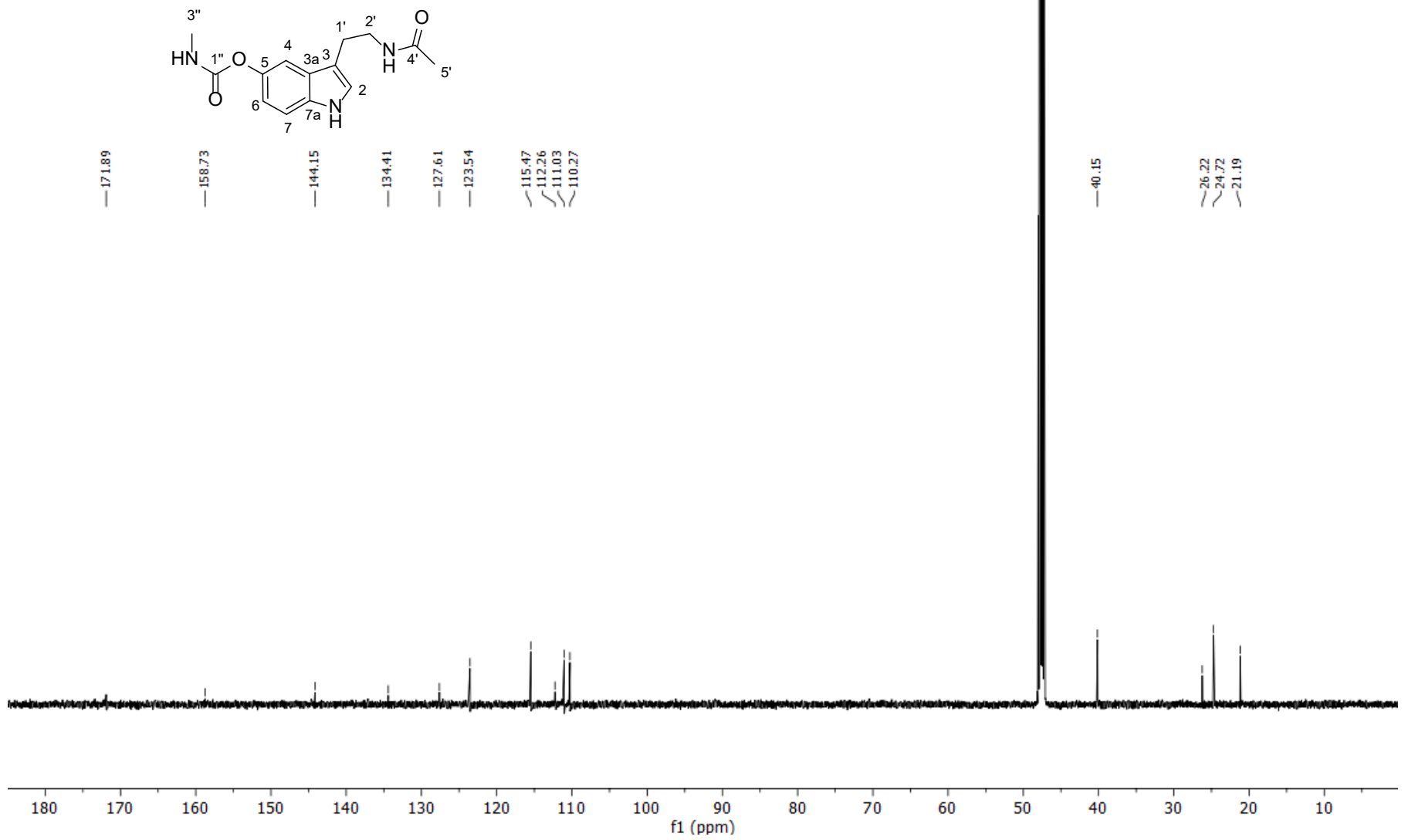

Figure S16. ${ }^{13} \mathrm{C}$ NMR spectrum $(150 \mathrm{MHz})$ of 5-O-methyl-carbamoyl- $N$-acetylserotonin $(3)$ in methanol- $d_{4} . \delta[\mathrm{ppm}]=173.6(\mathrm{C}-$ 4'), 159.4 (C-1”), 145.8 (C-5), 136.1 (C-3a), 129.3 (C-2), 125.2 (C-7a), 117.2 (C-7), 113.9 (C-4) , 112.7 (C-3), 112.0 (C-6), 41.8 (C-2'), 27.9 (C-3’'), 26.4 (C-1') , 22.9 (C-5'). 


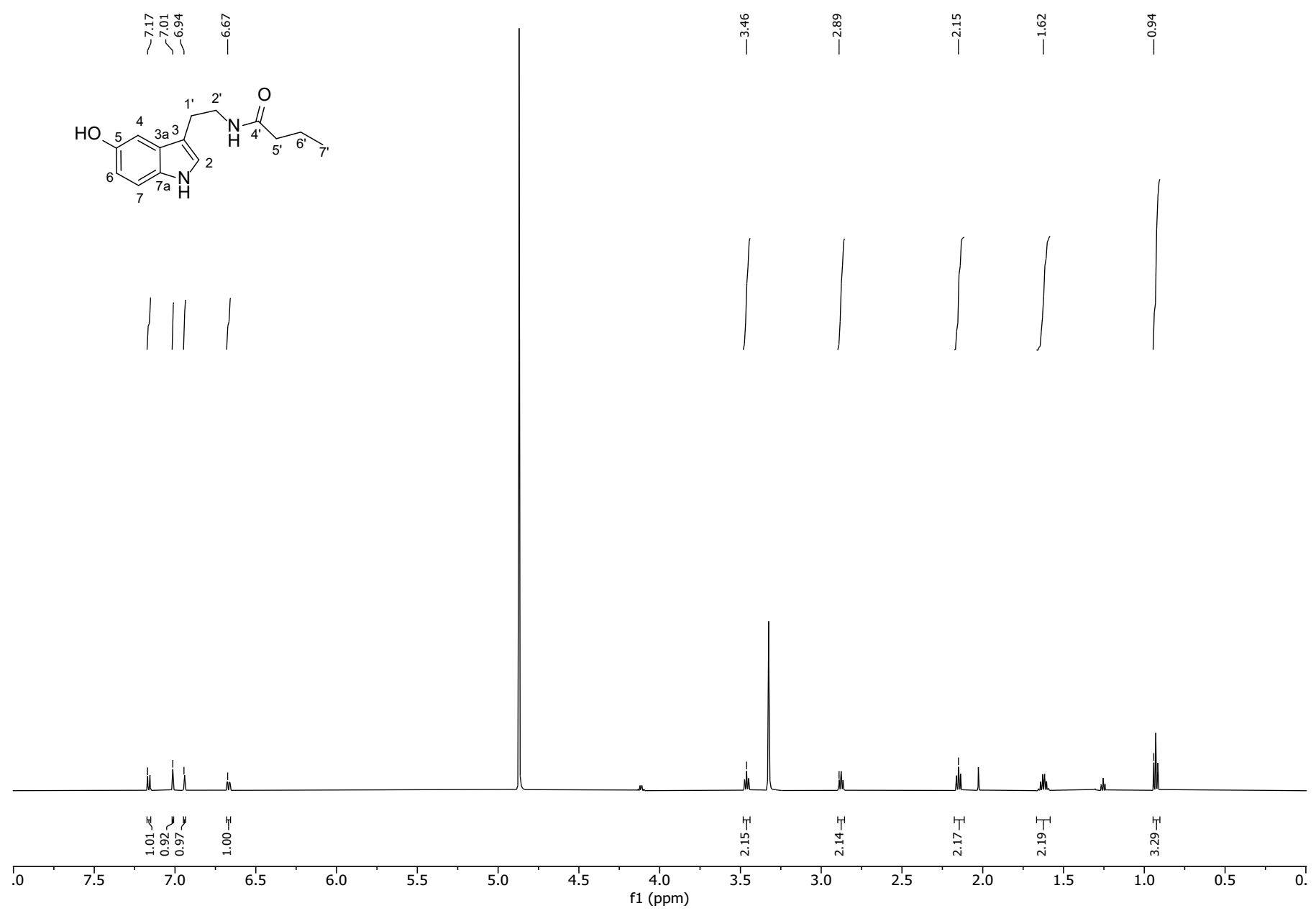

Figure S17. ${ }^{1} \mathrm{H}$ NMR spectrum $(600 \mathrm{MHz})$ of $N$-butyrlserotonin $(\mathbf{2 f})$ in methanol $-d_{4} . \delta[\mathrm{ppm}]=7.16\left(\mathrm{~d}, 1 \mathrm{H},{ }^{3} \mathrm{~J}_{7,6}=8.7 \mathrm{~Hz}, 7-\mathrm{H}\right)$, $7.01(\mathrm{~s}, 1 \mathrm{H}, 2-\mathrm{H}), 6.94\left(\mathrm{~d}, 1 \mathrm{H},{ }^{4} \mathrm{~J}_{4,6}=2.3 \mathrm{~Hz}, 4-\mathrm{H}\right), 6.84\left(\mathrm{dd}, 1 \mathrm{H},{ }^{3} \mathrm{~J}_{6,7}=8.7 \mathrm{~Hz},{ }^{4} \mathrm{~J}_{6,4}=2.3 \mathrm{~Hz}, 6-\mathrm{H}\right), 3.45\left(\mathrm{t}, 2 \mathrm{H},{ }^{3} \mathrm{~J}_{2},{ }^{\prime},=7.3 \mathrm{~Hz}, 2^{\prime}-\right.$

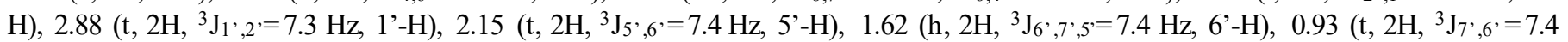
$\left.\mathrm{Hz}, 7^{\prime}-\mathrm{H}\right)$. Data was assigned by 2D NMR analysis. 


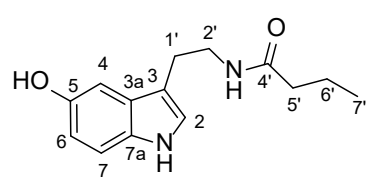

\begin{tabular}{|c|c|c|c|c|}
\hline 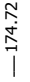 & 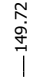 & 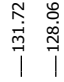 & $\begin{array}{l}\vec{\infty} \\
\stackrel{\sim}{\tilde{N}} \\
\overrightarrow{\mid}\end{array}$ & 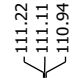 \\
\hline
\end{tabular}

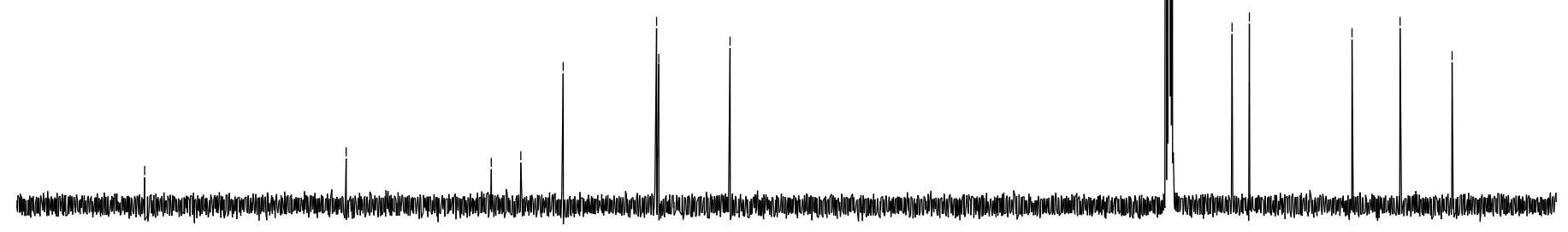

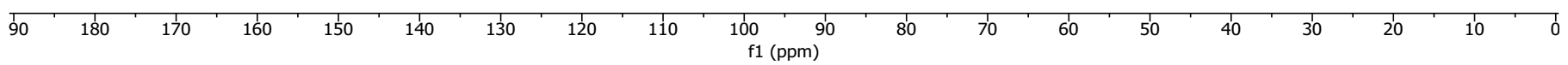

Figure S18. ${ }^{13} \mathrm{CNMR}$ spectrum $(150 \mathrm{MHz})$ of $N$-butyrylserotonin (2f) in methanol- $d 4 . \delta[\mathrm{ppm}]=174.7(\mathrm{C}-4$ '), 149.7 (C-5), 131.7 (C-7a), 128.1 (C-3a), 122.8 (C-2), 111.2 (C-6), 111.1 (C-3) , 110.9 (C-7), 102.1 (C-4), 39.8 (C-2'), 37.7 (C-5'), 25.0 (C-1'), 19.0 (C-6'), 12.6 (C-7'). 


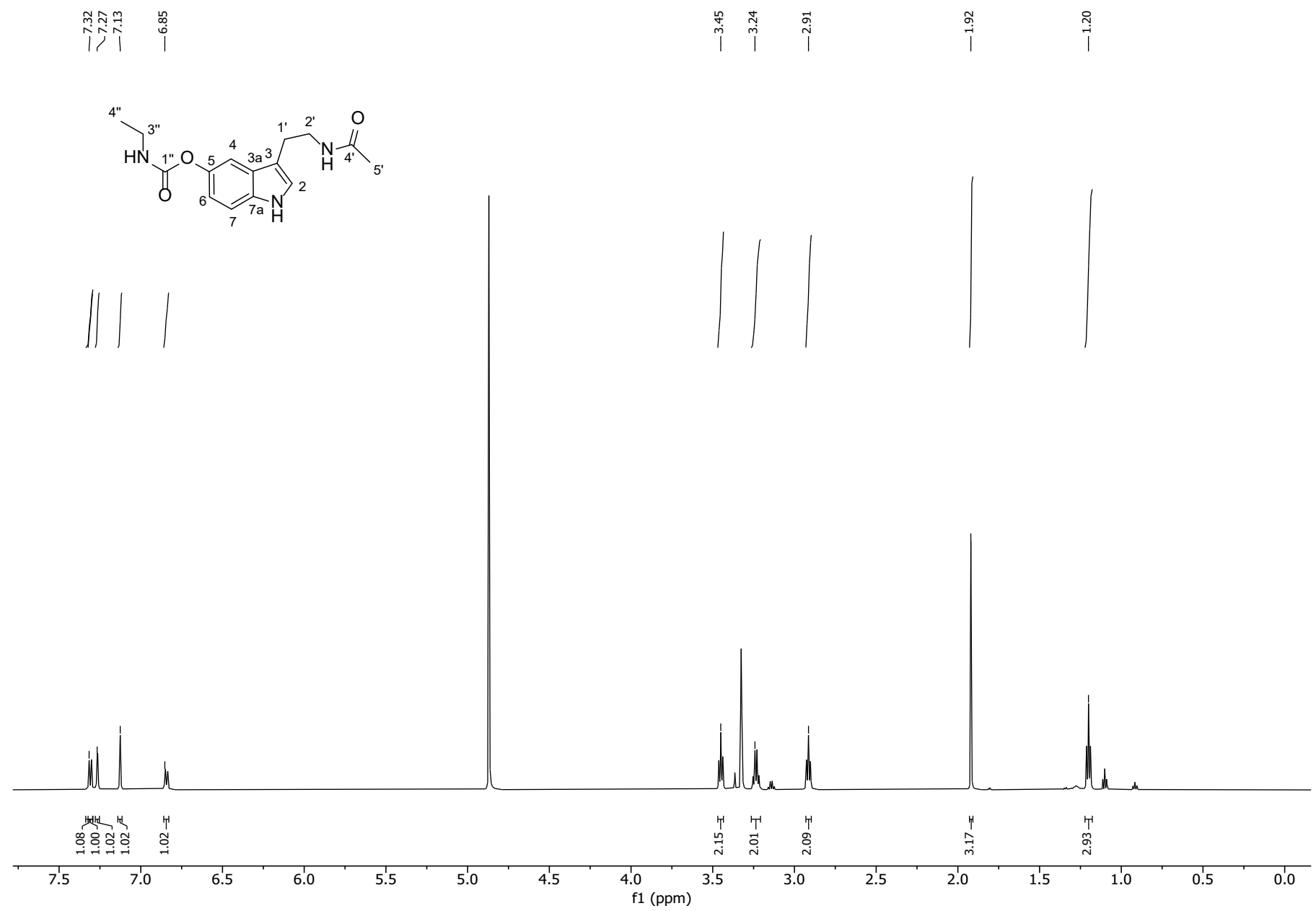

Figure S19. ${ }^{1} \mathrm{H}$ NMR spectrum $(600 \mathrm{MHz})$ of $N$-acetyl-5-ethylcarbamoyltryptamine (3a) in methanol- $d 4 . \delta[\mathrm{ppm}]=7.32(\mathrm{~d}, 1 \mathrm{H}$, $\left.{ }^{3} \mathrm{~J}_{7,6}=8.7 \mathrm{~Hz}, 7-\mathrm{H}\right), 7.27(\mathrm{~s}, 1 \mathrm{H}, 2-\mathrm{H}), 7.13(\mathrm{~s}, 1 \mathrm{H}, 4-\mathrm{H}), 6.85\left(\mathrm{~d}, 1 \mathrm{H},{ }^{3} \mathrm{~J}_{6,7}=8.7 \mathrm{~Hz}, 6-\mathrm{H}\right), 3.45\left(\mathrm{t}, 2 \mathrm{H},{ }^{3} \mathrm{~J}_{2}\right.$ ', $\left.{ }^{\prime},=7.2 \mathrm{~Hz}, 2^{\prime}-\mathrm{H}\right), 3.24$

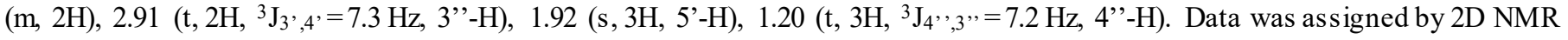
analysis. 

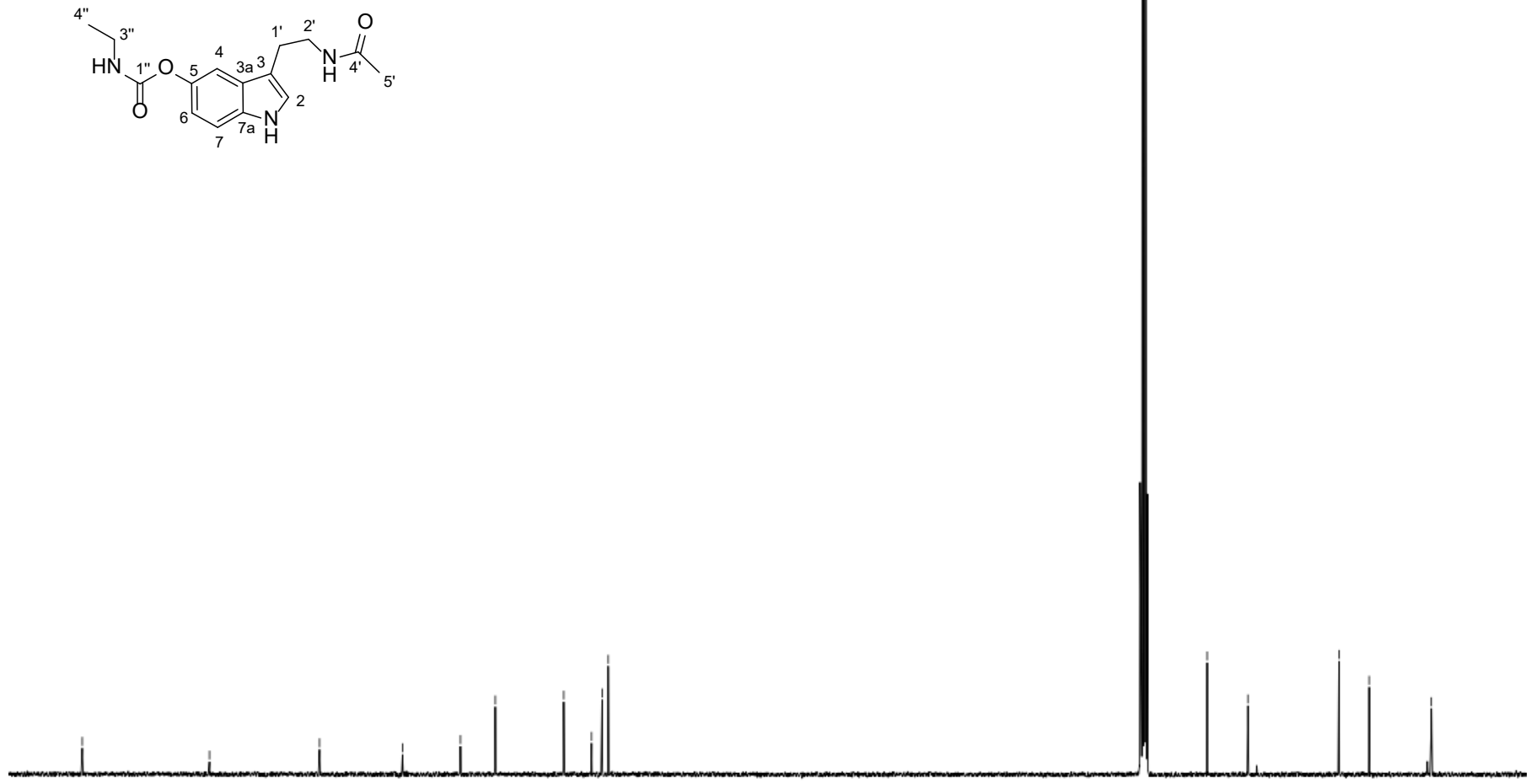

Figure S20. ${ }^{13} \mathrm{CNMR}$ spectrum $(150 \mathrm{MHz})$ of $N$-acetyl-5-ethylcarbamoyltryptamine (3a) in methanol- $d 4 . \delta[\mathrm{ppm}]=173.2(\mathrm{C}-4$ '), 158.3 (C-1'), 145.4 (C-5), 135.7 (C-7a), 128.9 (C-3a), 124.8 (C-2), 116.8 (C-6), 113.5 (C-3), 112.3 (C-7), 111.6 (C-4), 41.4 (C2'), 36.7 (C-3'’), 26.0 (C-1'), 22.5 (C-4'), 15.2 (C-5'). 

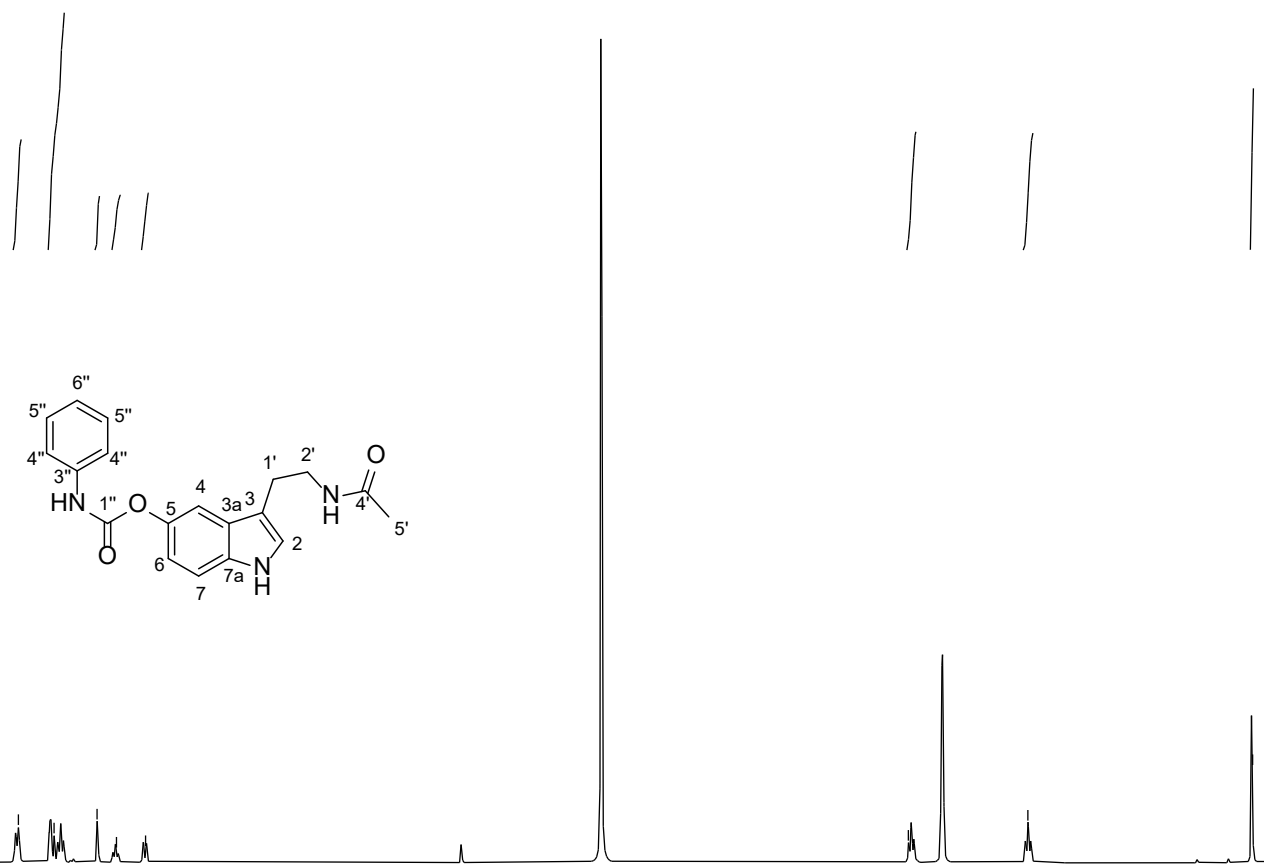

N
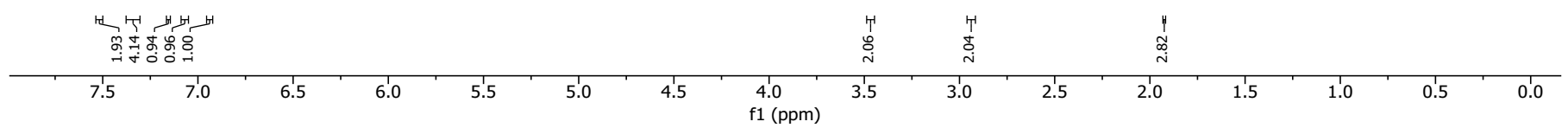

Figure S21. ${ }^{1} \mathrm{H}$ NMR spectrum $(600 \mathrm{MHz})$ of $N$-acetyl-5-phenylcarbamoyltryptamine $(\mathbf{3 b})$ in methanol- $d 4 . \delta[\mathrm{ppm}]=7.51(\mathrm{~d}, 2 \mathrm{H}$, ${ }^{3} \mathrm{~J}_{6}{ }^{\prime}, 7^{\prime},=8.6 \mathrm{~Hz}, 6$ '”-H), 7.38-7.30 (m, 4H, 7-H, 7''-H, 4-H), $7.16(\mathrm{~s}, 1 \mathrm{H}, 2-\mathrm{H}), 7.07\left(\mathrm{~m}, 1 \mathrm{H}, 8{ }^{\prime \prime}-\mathrm{H}\right), 6.94\left(\mathrm{~d}, 1 \mathrm{H},{ }^{3} \mathrm{~J}_{6,7}=8.6 \mathrm{~Hz}, 6-\right.$ H), $3.48\left(\mathrm{t}, 2 \mathrm{H},{ }^{3} \mathrm{~J}_{2^{\prime},},{ }^{\prime}=7.3 \mathrm{~Hz}, 2^{\prime}-\mathrm{H}\right), 2.94\left(\mathrm{t}, 2 \mathrm{H},{ }^{3} \mathrm{~J}_{1^{\prime}, 2^{\prime}}=7.3 \mathrm{~Hz}, 1^{\prime}-\mathrm{H}\right), 1.92\left(\mathrm{~s}, 3 \mathrm{H}, 5^{\prime}-\mathrm{H}\right)$. Data was assigned by 2D NMR analysis. 

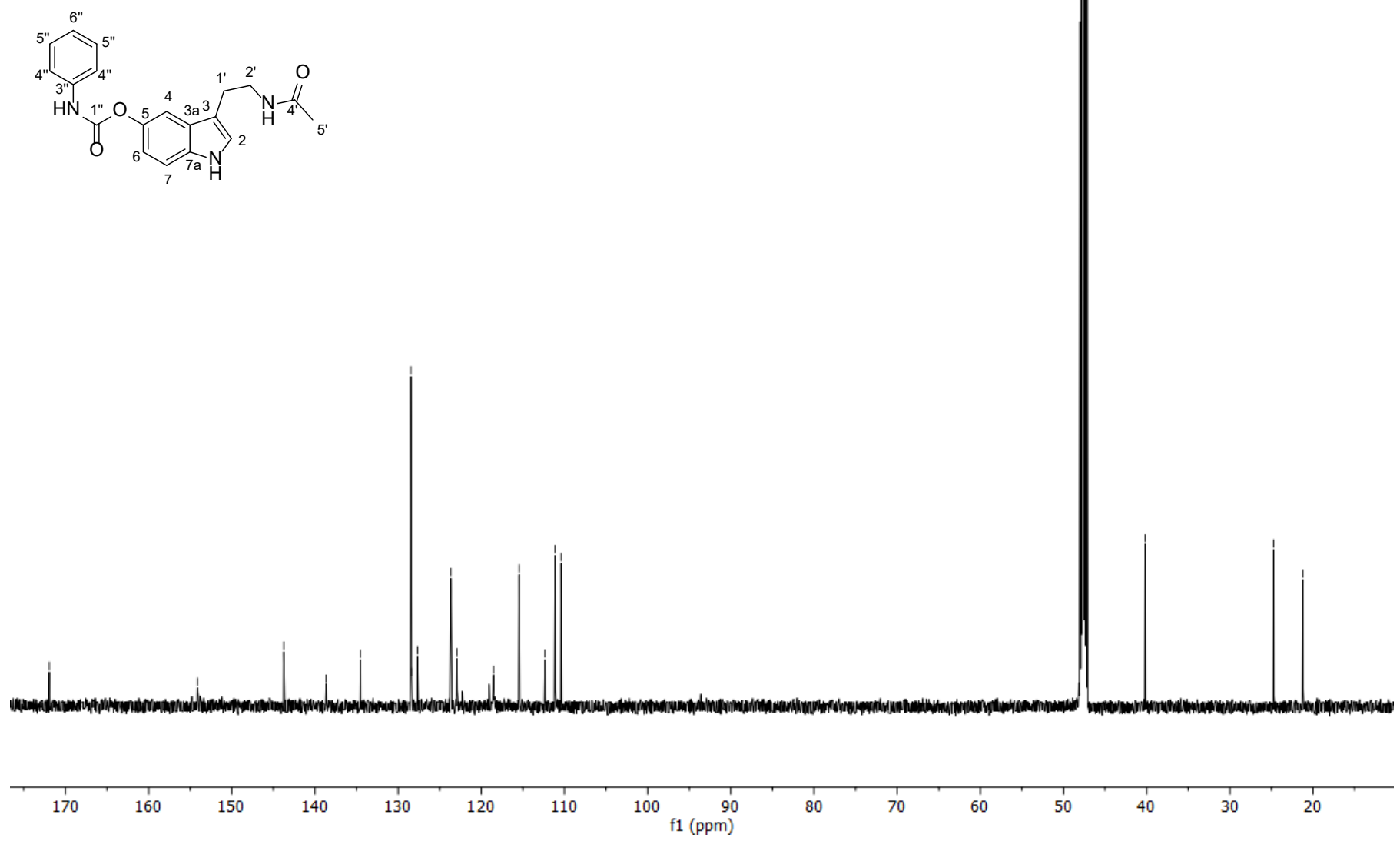

Figure S22. ${ }^{13} \mathrm{C}$ NMR spectrum $(150 \mathrm{MHz})$ of $N$-acetyl-5-phenylcarbamoyltryptamine $(\mathbf{3 b})$ in methanol- $d 4 . \delta[\mathrm{ppm}]=173.6(\mathrm{C}$ 4'), 155.8 (C-1'), 145.4 (C-5), 140.4 (C-3'’) 136.1 (C-7a), 130.2 (C-5'), 129.4 (C-3a), 125.3 (C-2), 124.6 (C-6’'), 120.3 (C-4'’), 117.1 (C-6), 114.0 (C-3) , 112.8 (C-7), 112.1 (C-4), 41.9 (C-2'), 26.4 (C-1'), 22.9 (C-5'). 


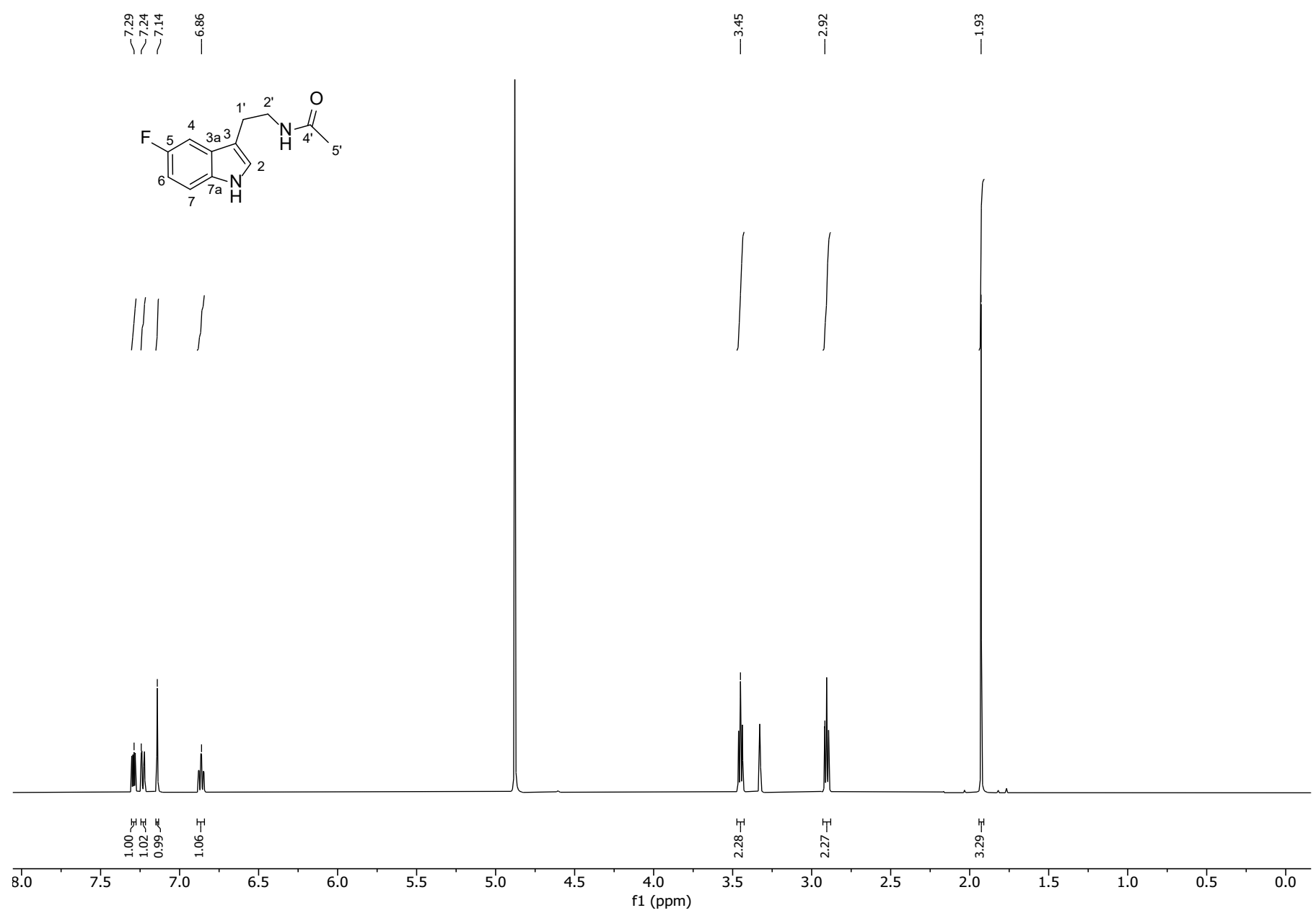

Figure S23. ${ }^{1} \mathrm{H}$ NMR spectrum $(600 \mathrm{MHz})$ of $N$-acetyl-5-fluorotryptamine $(\mathbf{3 c})$ in methanol- $d_{4} . \delta[\mathrm{ppm}]=7.29(\mathrm{~m}, 1 \mathrm{H}, 7-\mathrm{H}), 7.24$ $\left(\mathrm{dd}, 1 \mathrm{H},{ }^{4} \mathrm{~J}_{4,6,7}=2.5 \mathrm{~Hz}, 4-\mathrm{H}\right), 7.14(\mathrm{~s}, 1 \mathrm{H}), 6.86\left(\mathrm{td}, 1 \mathrm{H},{ }^{3} \mathrm{~J}_{6,7}=9.1,{ }^{4} \mathrm{~J}_{6,4}=2.5 \mathrm{~Hz}, 6-\mathrm{H}\right), 3.45\left(\mathrm{t}, 2 \mathrm{H},{ }^{3} \mathrm{~J}_{2}, 1^{\prime}=7.3 \mathrm{~Hz}, 2^{\prime}-\mathrm{H}\right), 2.92(\mathrm{t}$, $\left.2 \mathrm{H},{ }^{3} \mathrm{~J}_{1}, 2^{\prime},=7.3 \mathrm{~Hz}, 1^{\prime}-\mathrm{H}\right), 1.93\left(\mathrm{~s}, 3 \mathrm{H}, 5^{\prime}-\mathrm{H}\right)$. Data was assigned by 2D NMR analysis. 

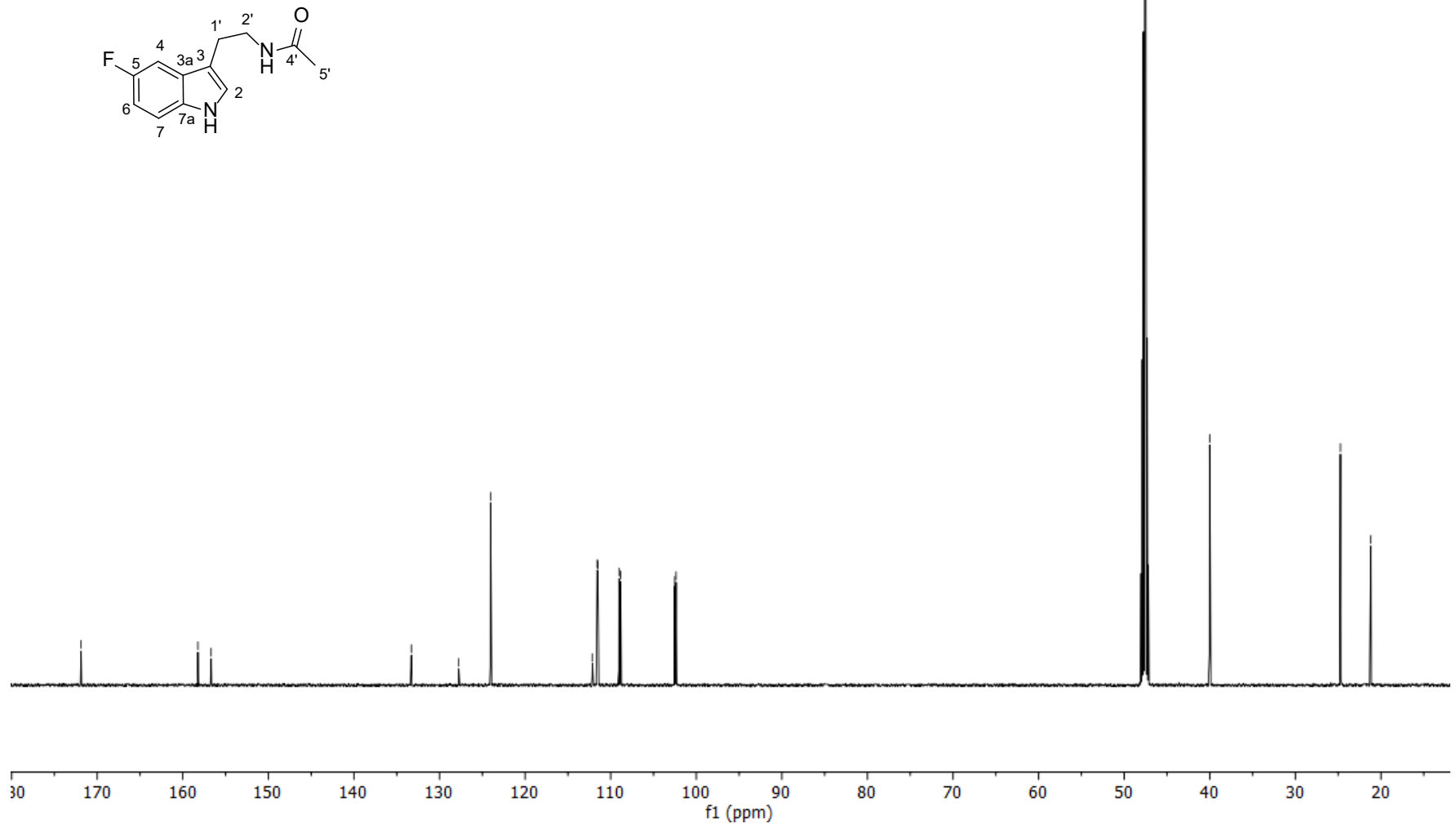

Figure S24. ${ }^{13} \mathrm{C}$ NMR spectrum $(150 \mathrm{MHz})$ of $N$-acetyl-5-fluorotryptamine $(3 \mathrm{c})$ in methanol- $d_{4} . \delta[\mathrm{ppm}]=171.9(\mathrm{C}-4$ '), $158.2(\mathrm{C}-$ 5), 156.0 (C-7a), 133.3 (C-3a), 124.0 (C-2), 112.1 (C-3), 111.5 (C-6), 109.0 (C-7), 102.5 (C-4), 40.0 (C-2'), 24.7 (C-1'), 21.2 (C5'). 


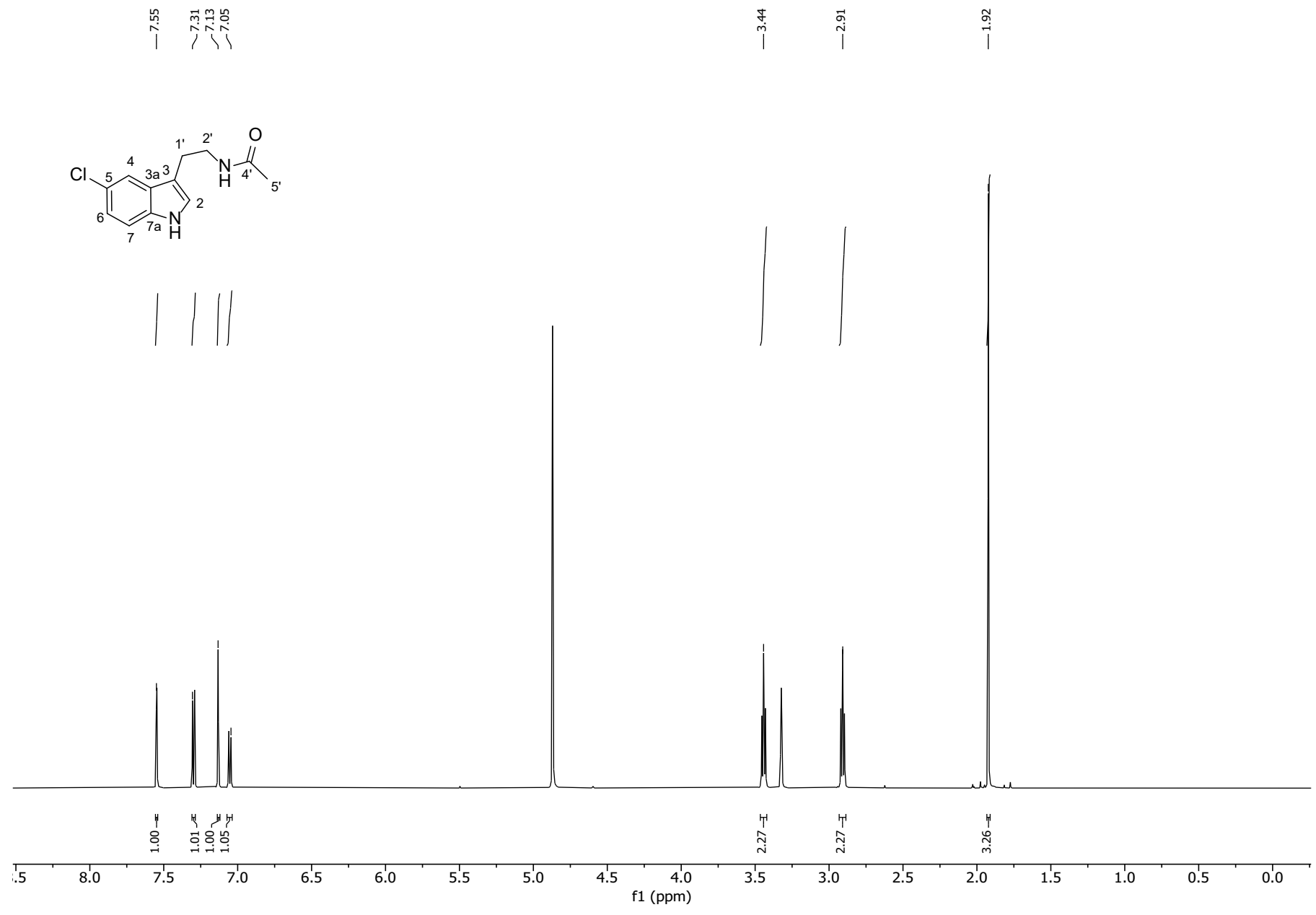

Figure S25. ${ }^{1} \mathrm{H}$ NMR spectrum $(600 \mathrm{MHz})$ of $N$-acetyl-5-chlorotryptamine $(3 \mathrm{~d})$ in methanol- $d_{4} . \delta[\mathrm{ppm}]=7.55(\mathrm{~s}, 1 \mathrm{H}, 7-\mathrm{H})$, 7.31 $\left(\mathrm{d}, 1 \mathrm{H},{ }^{4} \mathrm{~J}_{4,6}=2.5 \mathrm{~Hz}, 4-\mathrm{H}\right), 7.13(\mathrm{~s}, 1 \mathrm{H}), 7.05\left(\mathrm{td}, 1 \mathrm{H},{ }^{3} \mathrm{~J}_{6,7}=9.1,{ }^{4} \mathrm{~J}_{6,4}=2.5 \mathrm{~Hz}, 6-\mathrm{H}\right), 3.44\left(\mathrm{t}, 2 \mathrm{H},{ }^{3} \mathrm{~J}_{2},{ }_{1},=7.3 \mathrm{~Hz}, 2^{\prime}-\mathrm{H}\right), 2.91(\mathrm{t}, 2 \mathrm{H}$, $\left.{ }^{3} \mathrm{~J}_{1}, 2,=7.3 \mathrm{~Hz}, 1^{\prime}-\mathrm{H}\right), 1.92\left(\mathrm{~s}, 3 \mathrm{H}, 5^{\prime}-\mathrm{H}\right)$. Data was assigned by 2D NMR analysis. 

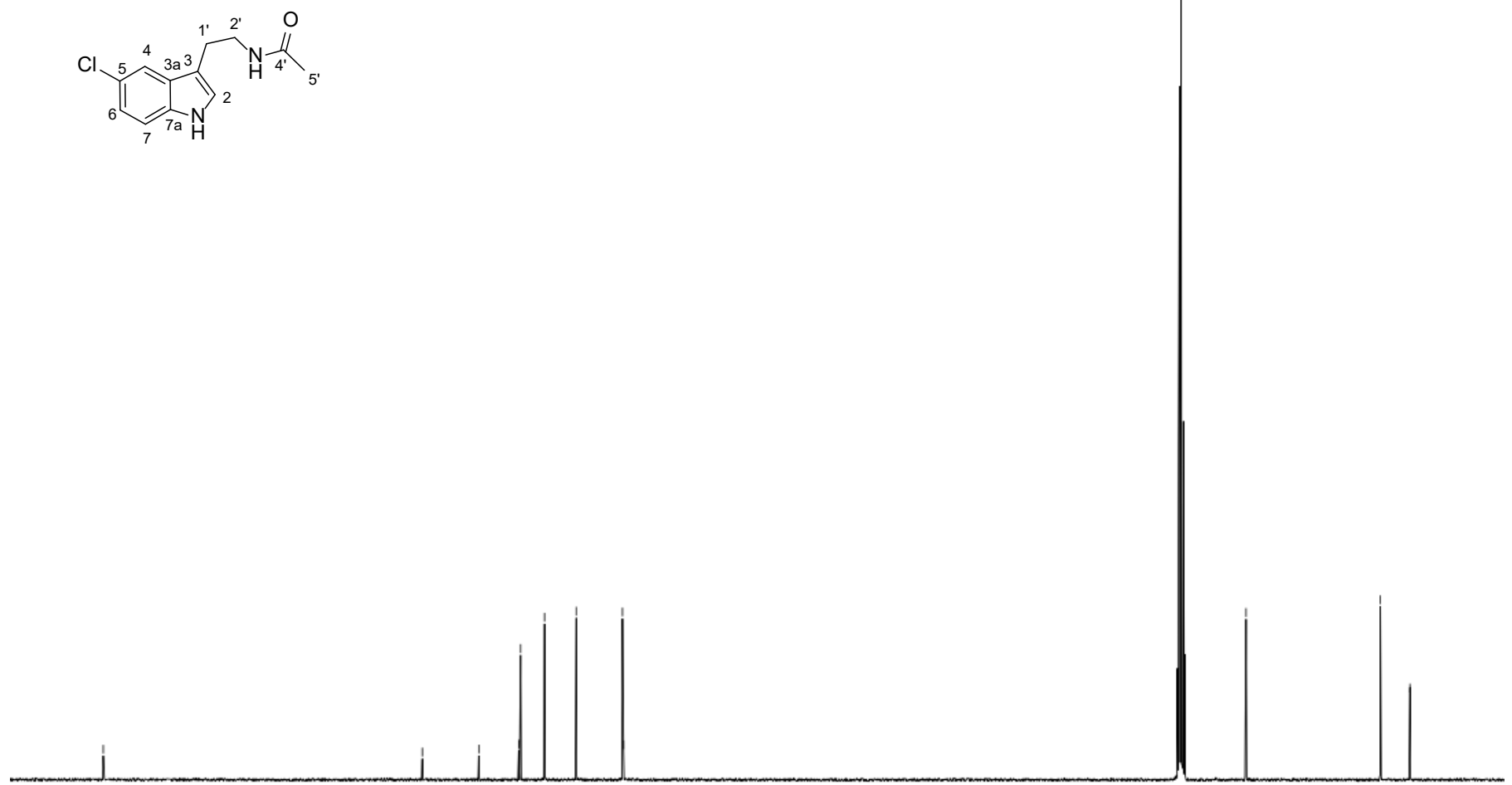

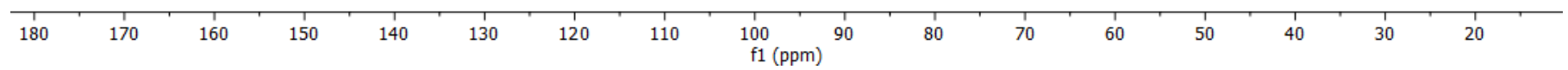

Figure S26. ${ }^{13} \mathrm{CNMR}$ spectrum $(150 \mathrm{MHz})$ of $N$-acetyl-5-chlorotryptamine $(3 \mathrm{dd})$ in methanol- $d_{4} . \delta[\mathrm{ppm}]=172.0\left(\mathrm{C}-4^{\prime}\right), 135.2(\mathrm{C}-$ 5), 128.0 (C-7a), 124.1 (C-3a), 123.7 (C-2), 121.0 (C-6), 117.2 (C-7), 112.0 (C-4), 111.9 (C-3), 40.3 (C-2'), 24.6 (C-1'), 21.4 (C5'). 


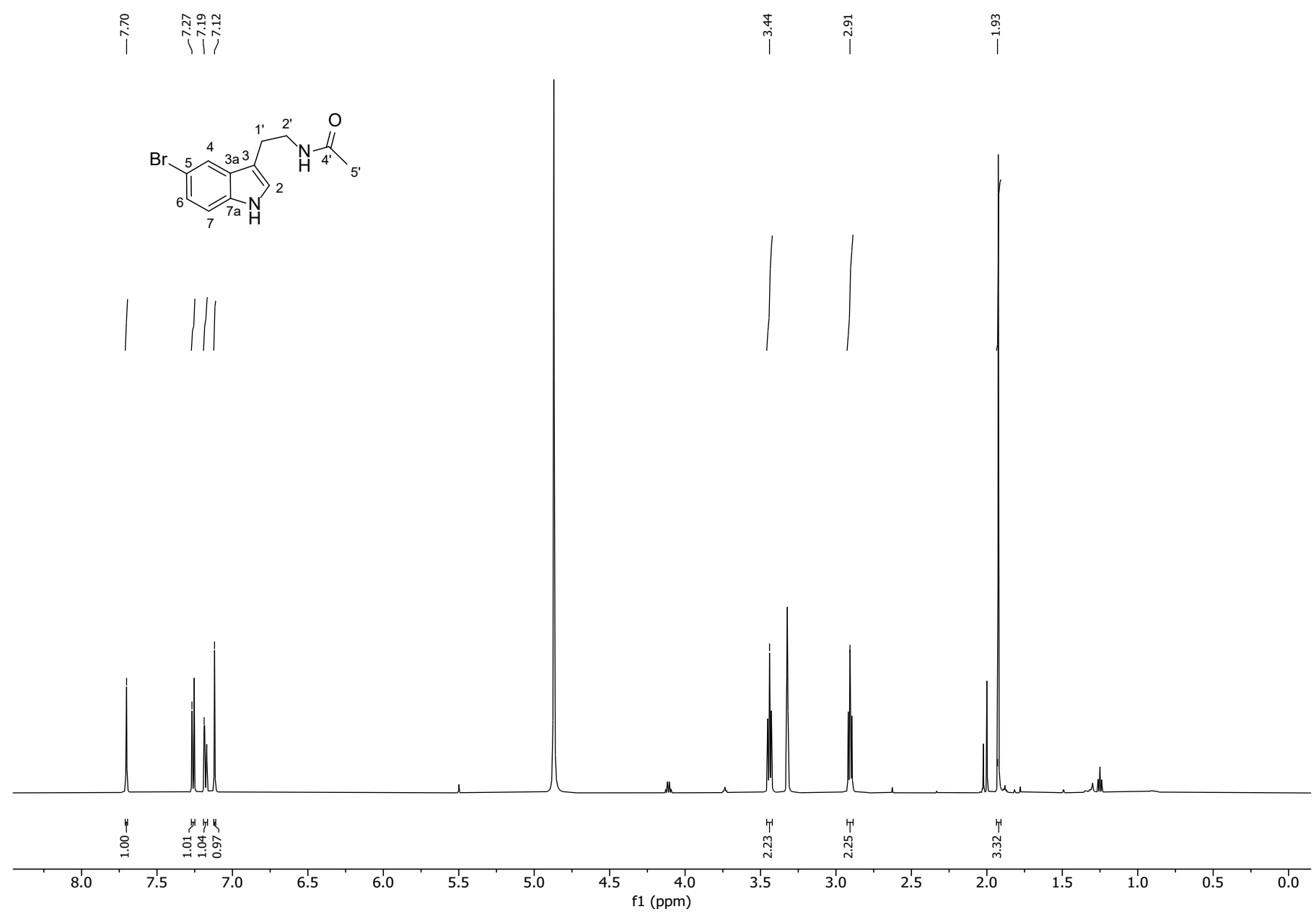

Figure S27. ${ }^{1} \mathrm{H}$ NMR spectrum $(600 \mathrm{MHz})$ of $N$-acetyl-5-bromotryptamine $(3 \mathbf{e})$ in methanol- $d_{4} . \delta[\mathrm{ppm}]=7.70(\mathrm{~s}, 1 \mathrm{H}, 7-\mathrm{H})$, 7.27 $\left(\mathrm{d}, 1 \mathrm{H},{ }^{4} \mathrm{~J}_{4,6}=2.5 \mathrm{~Hz}, 4-\mathrm{H}\right), 7.19\left(\mathrm{td}, 1 \mathrm{H},{ }^{3} \mathrm{~J}_{6,7}=9.1,{ }^{4} \mathrm{~J}_{6,4}=2.5 \mathrm{~Hz}, 6-\mathrm{H}\right), 7.12(\mathrm{~s}, 1 \mathrm{H}), 3.44\left(\mathrm{t}, 2 \mathrm{H},{ }^{3} \mathrm{~J}_{2},{ }^{\prime},=7.3 \mathrm{~Hz}, 2^{\prime}-\mathrm{H}\right), 2.91(\mathrm{t}, 2 \mathrm{H}$, $\left.{ }^{3} \mathrm{~J}_{1}, 2,=7.3 \mathrm{~Hz}, 1^{\prime}-\mathrm{H}\right), 1.93$ (s, 3H, 5'-H). Data was assigned by 2D NMR analysis. 
<smiles>CC(=O)NCCc1c[nH]c2ccc(Br)cc12</smiles>
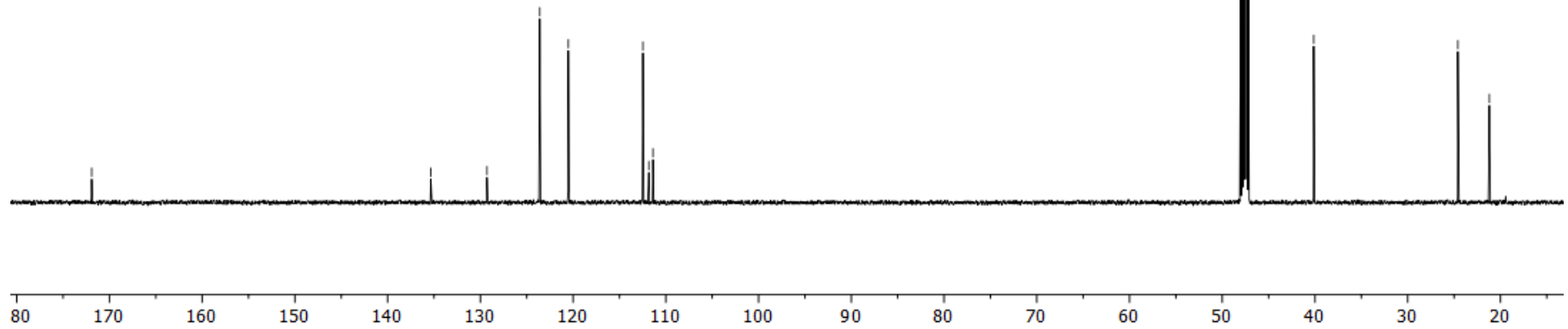

$130+1$

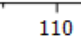

$\begin{array}{ll}100 & 90 \\ \mathrm{f} 1(\mathrm{ppm}) & \end{array}$

Figure S28. ${ }^{13} \mathrm{CNMR}$ spectrum $(150 \mathrm{MHz})$ of $N$-acetyl-5-bromotryptamine $(3 \mathbf{e})$ in methanol- $d_{4} . \delta[\mathrm{ppm}]=171.2(\mathrm{C}-4$ '), $135.4(\mathrm{C}-$ 5), 129.3 (C-7a), 123.6 (C-6), 120.6 (C-7), 112.5 (C-4), 111.7 (C-3a), 111.5 (C-3), 40.1 (C-2'), 24.5 (C-1'), 21.2 (C-5’). 


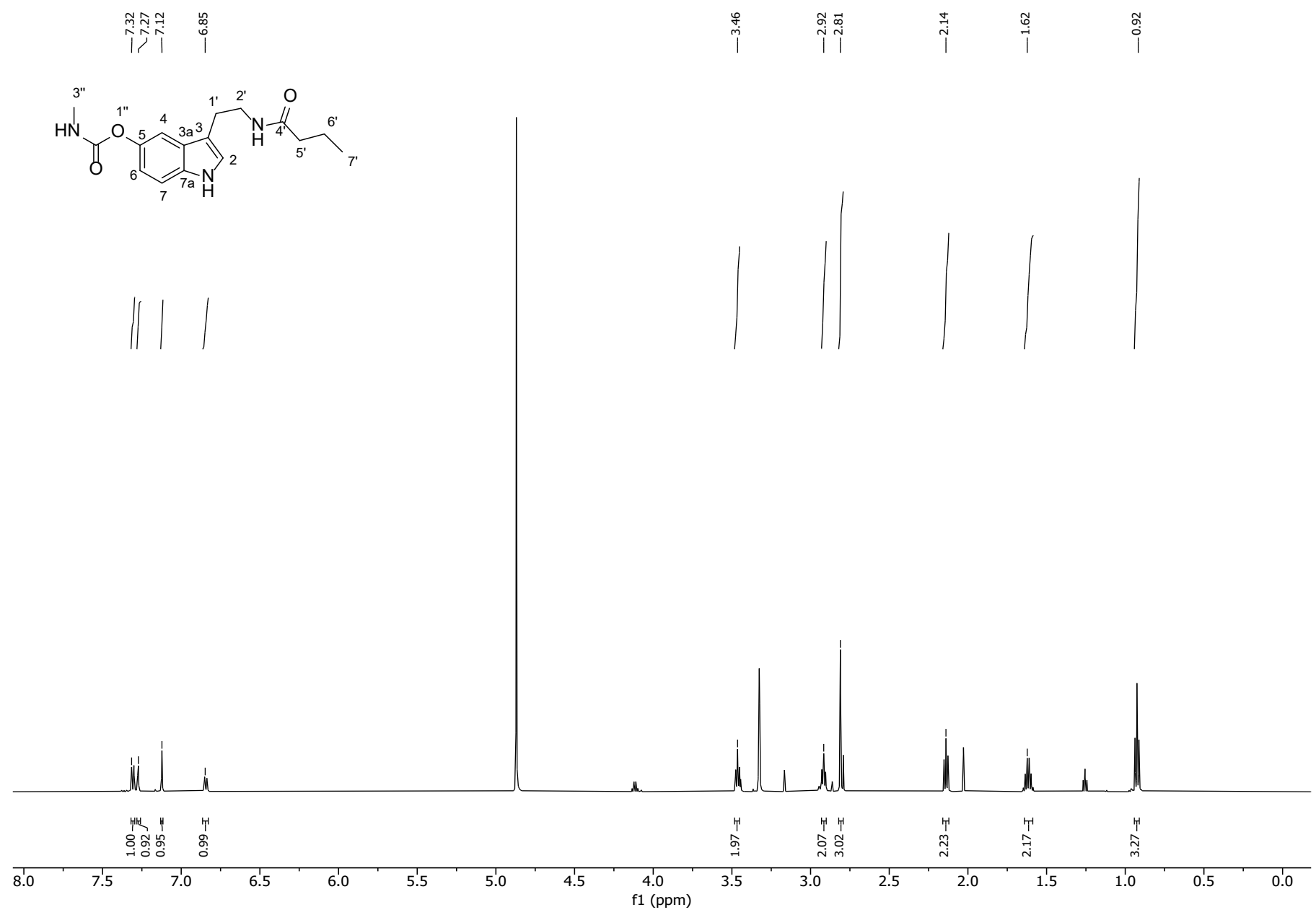

Figure S29. ${ }^{1} \mathrm{H}$ NMR spectrum $(600 \mathrm{MHz})$ of $N$-butyryl-5-carbamoyl-tryptamine $(\mathbf{3 f})$ in methanol- $d_{4} . \delta[\mathrm{ppm}]=7.31\left(\mathrm{~d}, 1 \mathrm{H},{ }^{3} \mathrm{~J}_{7,6}\right.$ $=8.7 \mathrm{~Hz}, 7-\mathrm{H}), 7.27(\mathrm{~s}, 1 \mathrm{H}, 2-\mathrm{H}), 7.12(\mathrm{~s}, 1 \mathrm{H}, 4-\mathrm{H}), 6.84\left(\mathrm{~d}, 1 \mathrm{H},{ }^{3} \mathrm{~J}_{6,7}=8.7 \mathrm{~Hz}, 6-\mathrm{H}\right), 3.46\left(\mathrm{t}, 2 \mathrm{H},{ }^{3} \mathrm{~J}_{2}, \mathrm{l}^{\prime}=7.3 \mathrm{~Hz}, 2^{\prime}-\mathrm{H}\right), 2.92(\mathrm{t}, 2 \mathrm{H}$,

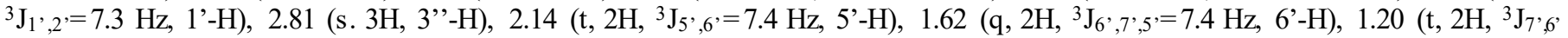
$\left.=7.4 \mathrm{~Hz}, 7^{\prime}-\mathrm{H}\right)$. Data was assigned by 2D NMR analysis. 


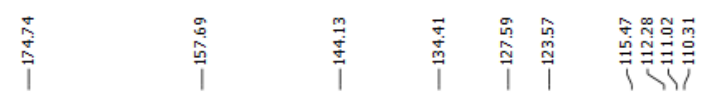

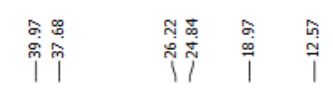
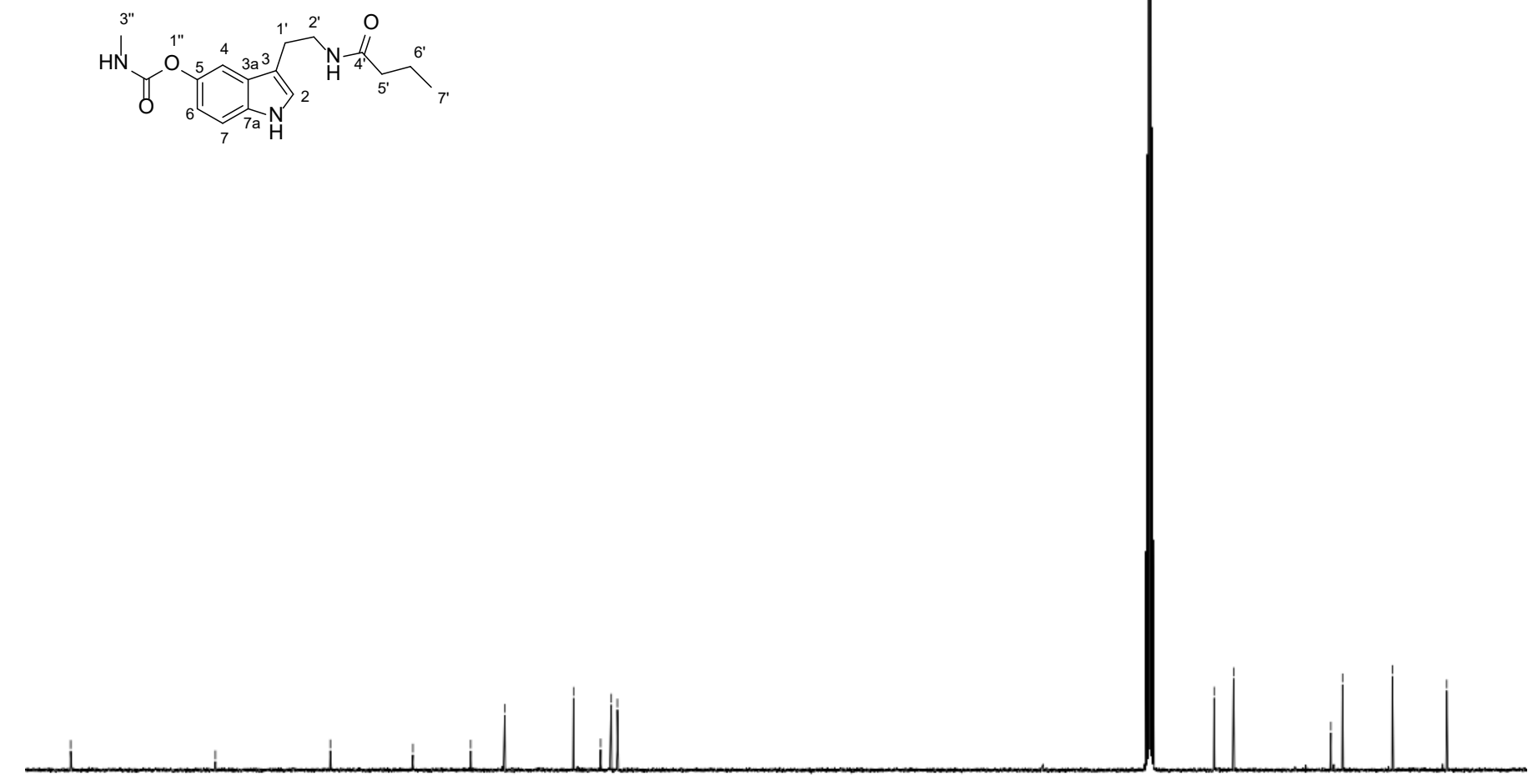

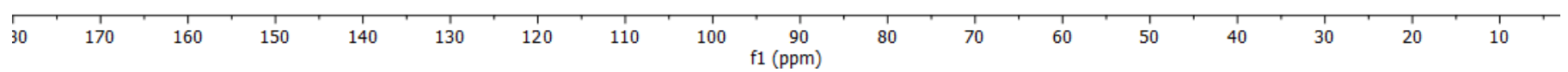

Figure S30. ${ }^{13} \mathrm{C}$ NMR spectrum $(150 \mathrm{MHz})$ of $N$-butyryl-5-carbamoyl-tryptamine $(\mathbf{3 f})$ in methanol- $d_{4} . \delta[\mathrm{ppm}]=174.7(\mathrm{C}-4$ ') 157.7 (C-1'”), 144.1 (C-5), 134.4 (C-7a), 127.6 (C-3a), 123.6 (C-2), 115.5 (C-6), 112.3 (C-3) , 111.0 (C-7), 110.3 (C-4), 40.0 (C2'), 37.7 (C-5') 26.2 (C-3'’), 24.8 (C-1), 19.0 (C-6'), 12.6 (C-7'). 


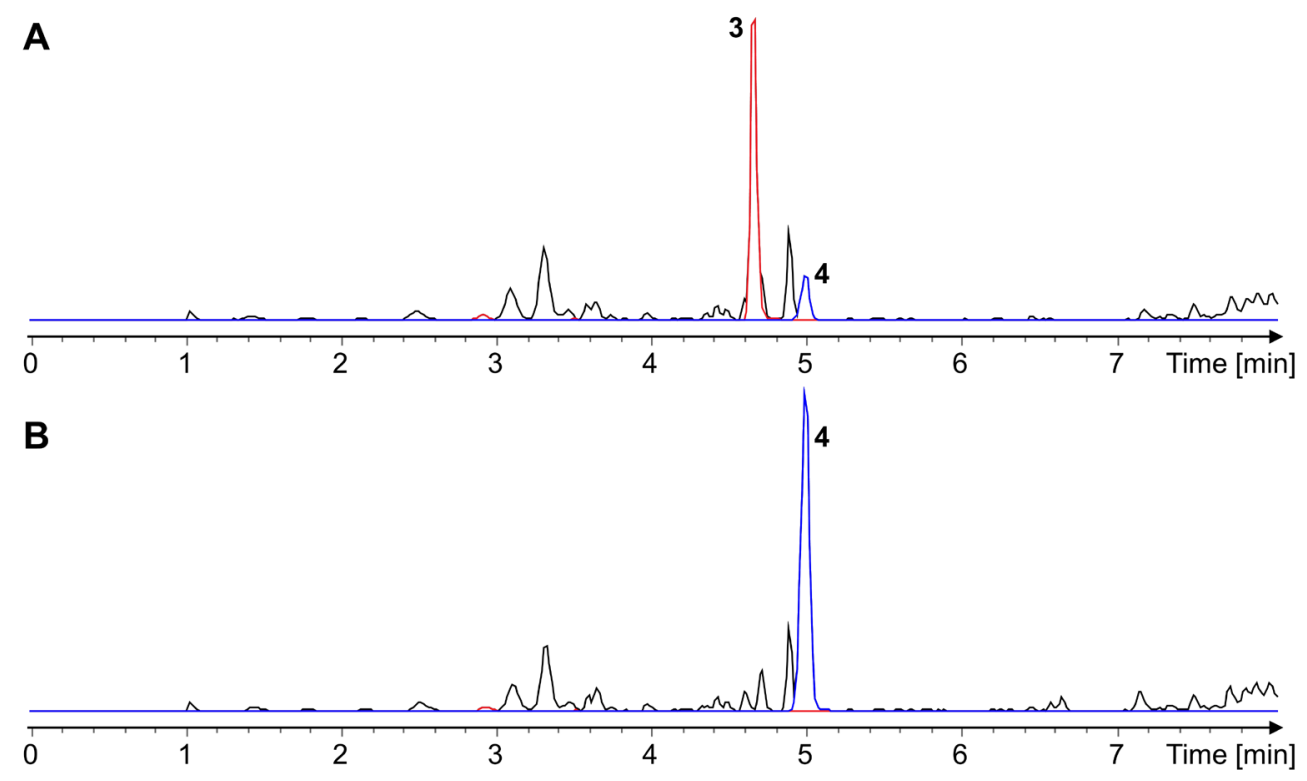

Figure S31. Total ion chromatograms of the raw extracts from M. xanthus FB:pMEX07 (without fusion protein) (A) and M. xanthus FB:pMEX05 (with fusion protein) (B), fed with $40 \mathrm{mg} / \mathrm{L}$ 5- $O$-methyl-carbamoyl- $N$-acetylserotonin (3). Red: EIC of substrate $3(\mathrm{~m} / \mathrm{z}$ 276.13). Blue: EIC of product $4(\mathrm{~m} / \mathrm{z} 290.15)$.

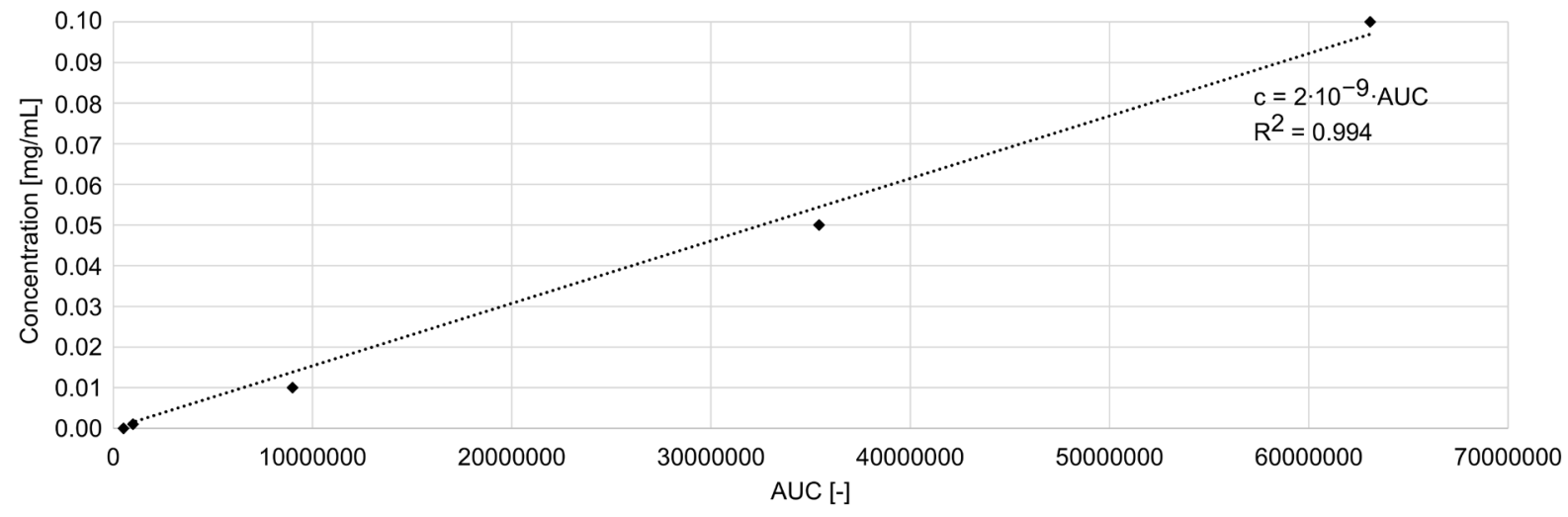

Figure S32. Linear correlation between the total AUC of physostigmine (7) and eseroline (9) EICs and the physostigmine (7) concentration. The calibration curve was obtained with commercial physostigmine (Alfa aesar). 
A
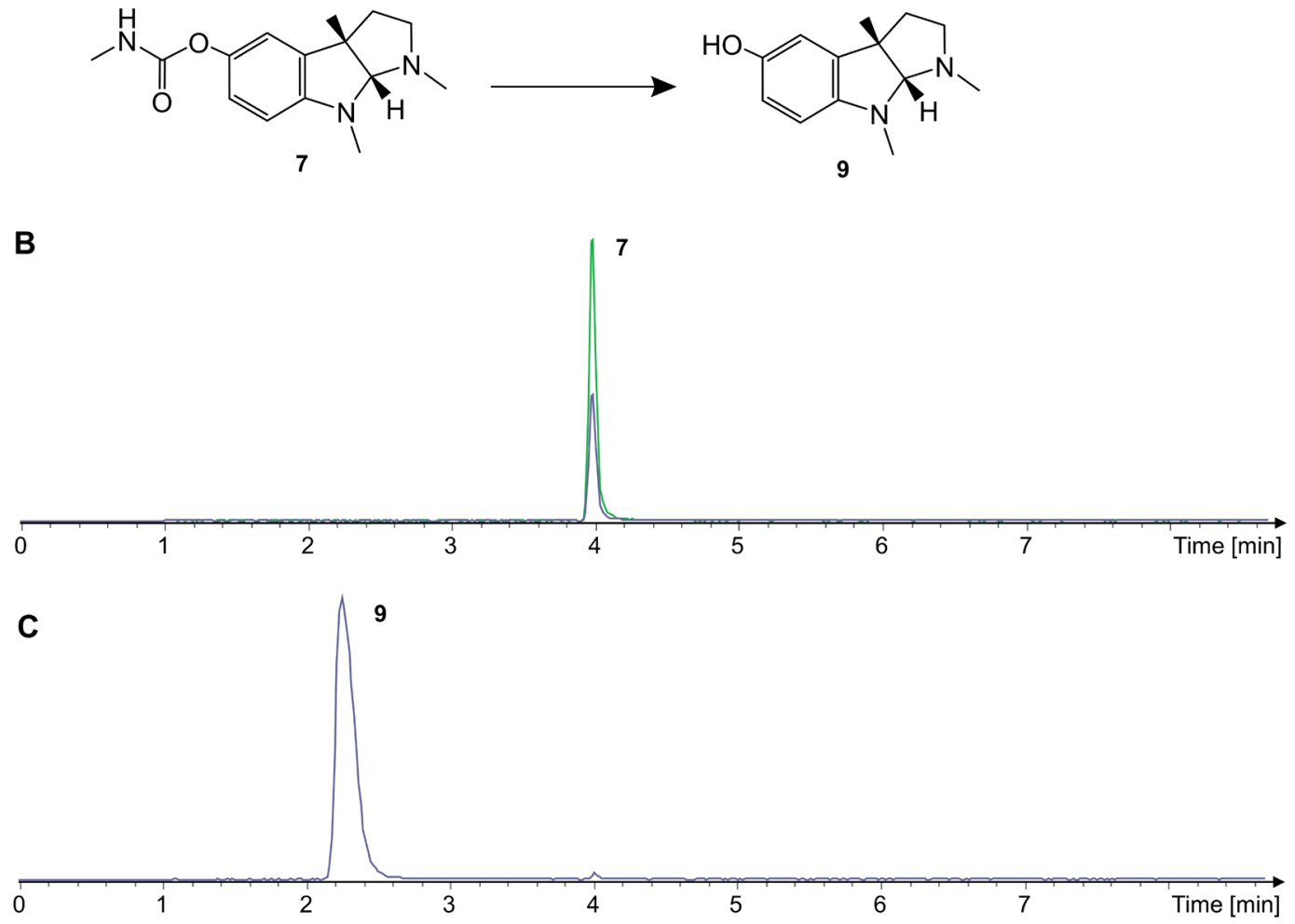

Figure S33. Degradation of physostigmine (7) to eseroline (9) (A). Total ion chromatogram of 7 (analytical standard, Alfa aesar) (B). Total ion chromatogram of 9 (analytical standard, Sigma Aldrich) (C). Green: EIC of $7(\mathrm{~m} / z 2276.17)$, Grey: EIC of $9(\mathrm{~m} / z$ 219.15). 
Table S4. Physostigmine (7) titer from cultures of $M$. xanthus FB:pMEX04. All cultures were cultivated for 3 days in 100 mL CTPM supplemented with $40 \mathrm{mg} / \mathrm{L}$ 5-O-methyl-carbamoyl- $N$-acetylserotonin (3). n.d.: not detected.

\begin{tabular}{|c|c|c|c|}
\hline Clone & Titer $[\mathbf{m g} / \mathbf{L}]$ & Average titer $[\mathrm{mg} / \mathrm{L}]$ & Coefficient of variation $[\%]$ \\
\hline \multirow[t]{5}{*}{$\mathrm{D} 4.1$} & 0.38 & $0.15 \pm 0.13$ & 88.16 \\
\hline & 0.11 & & \\
\hline & 0.09 & & \\
\hline & 0.08 & & \\
\hline & 0.08 & & \\
\hline \multirow[t]{5}{*}{$\mathrm{D} 4.2$} & 1.36 & $1.97 \pm 0.81$ & 40.88 \\
\hline & 1.21 & & \\
\hline & 2.91 & & \\
\hline & 1.61 & & \\
\hline & 2.75 & & \\
\hline \multirow[t]{3}{*}{$\mathrm{D} 4.3$} & 2.66 & & \\
\hline & n.d. & & \\
\hline & n.d. & & \\
\hline \multirow[t]{5}{*}{$\mathrm{D} 4.4$} & 0.06 & & \\
\hline & n.d. & & \\
\hline & n.d. & & \\
\hline & n.d. & & \\
\hline & n.d. & & \\
\hline \multirow[t]{5}{*}{$\mathrm{D} 4.5$} & 0.26 & & \\
\hline & n.d. & & \\
\hline & n.d. & & \\
\hline & n.d. & & \\
\hline & n.d. & & \\
\hline Total average titer: & $1.04 \pm 1.12^{\mathrm{a}}$ & & 107.63 \\
\hline
\end{tabular}

aThe calculation of the total average titer was performed with values $>0$. 
Table S5. Physostigmine (7) titer from cultures of $M$. xanthus FB:pMEX10. All cultures were cultivated for 3 days in 100 mL CTPM supplemented with $40 \mathrm{mg} / \mathrm{L}$ 5-O-methyl-carbamoyl- $N$-acetylserotonin (3).

\begin{tabular}{|c|c|c|c|}
\hline Clone & Titer $[\mathrm{mg} / \mathbf{L}]$ & Average titer $[\mathrm{mg} / \mathrm{L}]$ & Coefficient of variation $[\%]$ \\
\hline \multirow[t]{6}{*}{ D1 } & 4.81 & $2.94 \pm 1.88$ & 63.97 \\
\hline & 3.96 & & \\
\hline & 4.41 & & \\
\hline & 3.23 & & \\
\hline & 0.54 & & \\
\hline & 0.68 & & \\
\hline \multirow[t]{5}{*}{$\mathrm{D} 2$} & 4.05 & $6.27 \pm 2.11$ & 33.679 \\
\hline & 7.71 & & \\
\hline & 4.35 & & \\
\hline & 8.94 & & \\
\hline & 6.29 & & \\
\hline \multirow[t]{5}{*}{ D3 } & 4.64 & $3.95 \pm 1.19$ & 30.19 \\
\hline & 2.56 & & \\
\hline & 3.99 & & \\
\hline & 5.51 & & \\
\hline & 3.04 & & \\
\hline \multirow[t]{6}{*}{$\mathrm{D} 4$} & 1.00 & $2.82 \pm 1.32$ & 46.84 \\
\hline & 2.98 & & \\
\hline & 4.66 & & \\
\hline & 3.91 & & \\
\hline & 2.27 & & \\
\hline & 2.10 & & \\
\hline \multirow[t]{5}{*}{$\mathrm{D} 5$} & 4.32 & $8.00 \pm 4.41$ & 55.13 \\
\hline & 11.98 & & \\
\hline & 10.42 & & \\
\hline & 11.04 & & \\
\hline & 2.23 & & \\
\hline Total average titer: & $4.65 \pm 3.02$ & & 64.88 \\
\hline
\end{tabular}


Table S6. Physostigmine (7) titer from cultures of $M$. xanthus NM:pMEX10. All cultures were cultivated for 3 days in 100 mL CTPM supplemented with $40 \mathrm{mg} / \mathrm{L}$ 5-O-methyl-carbamoyl- $N$-acetylserotonin (3).

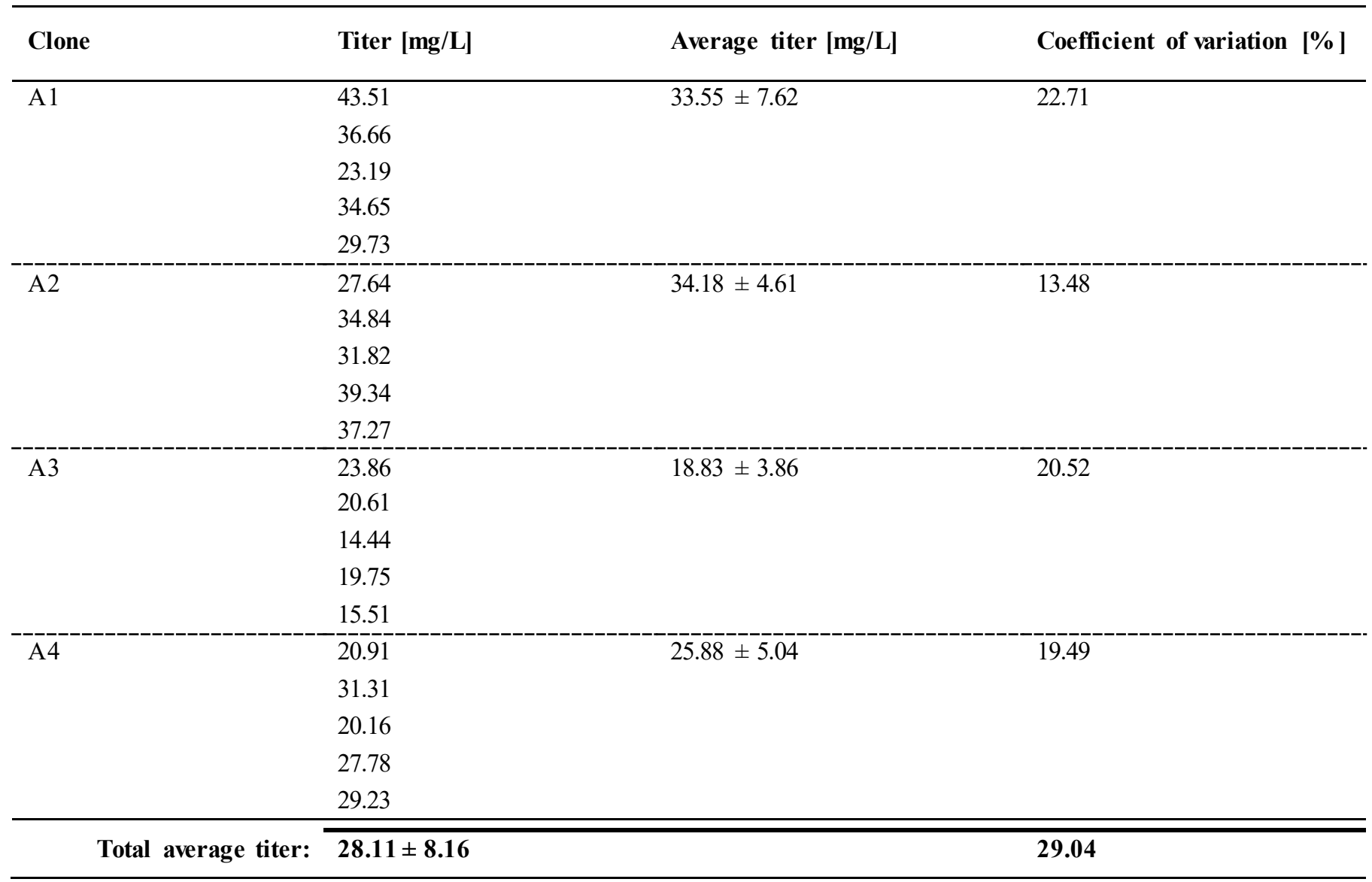

Table S7. Physostigmine (7) titer from cultures of $M$. xanthus NM:pMEX10. All cultures were cultivated for 3 days in 100 mL CTPM supplemented with $200 \mathrm{mg} / \mathrm{L}$ 5-O-methyl-carbamoyl- $N$-acetylserotonin (3).

\begin{tabular}{llll}
\hline Clone & Titer $[\mathbf{m g} / \mathbf{L}]$ & Average titer $[\mathbf{m g} / \mathbf{L}]$ & Coefficient of variation $[\%]$ \\
\hline A1 & 70.40 & $72.00 \pm 17.44$ & 24.22 \\
& 53.58 & & \\
& 68.43 & \\
& 95.61 & \\
\hline
\end{tabular}




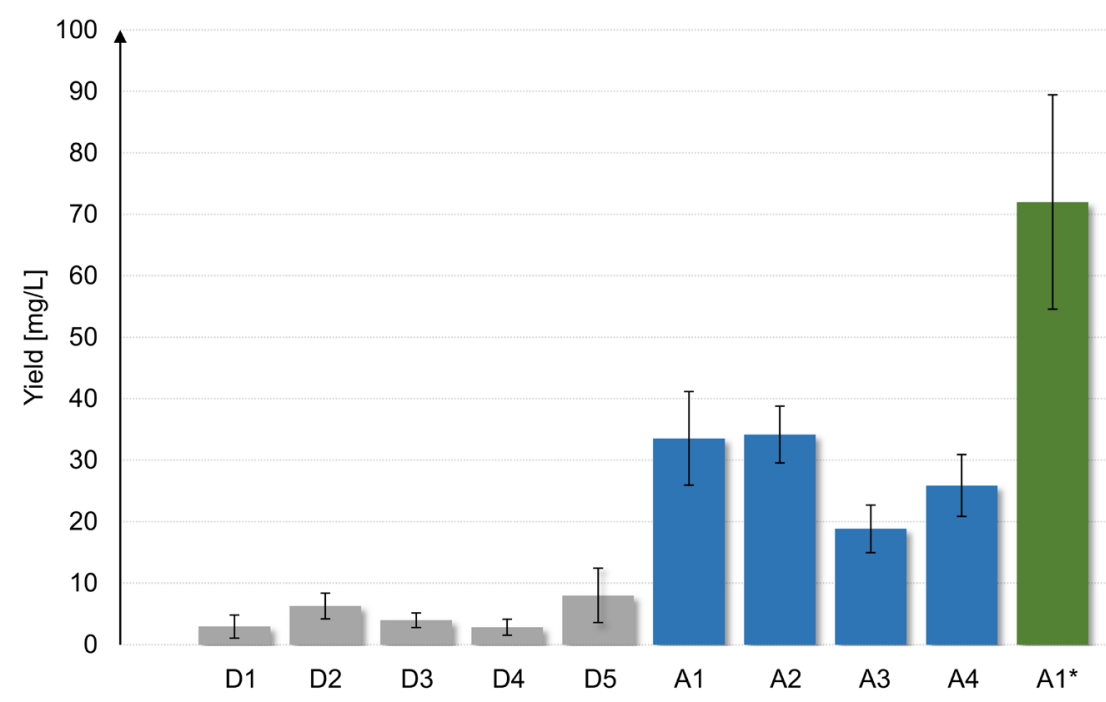

Figure S34. Physostigmine (7) titer in mg perliter cultivation volume. D1-D5: M. xanthus FB:pMEX10 clone 1-5, A1-A4: M. xanthus NM:pMEX10 clone 1-4, A1*: M. xanthus NM:pMEX10 clone 1 with increased substrate concentration (200 mg/L).

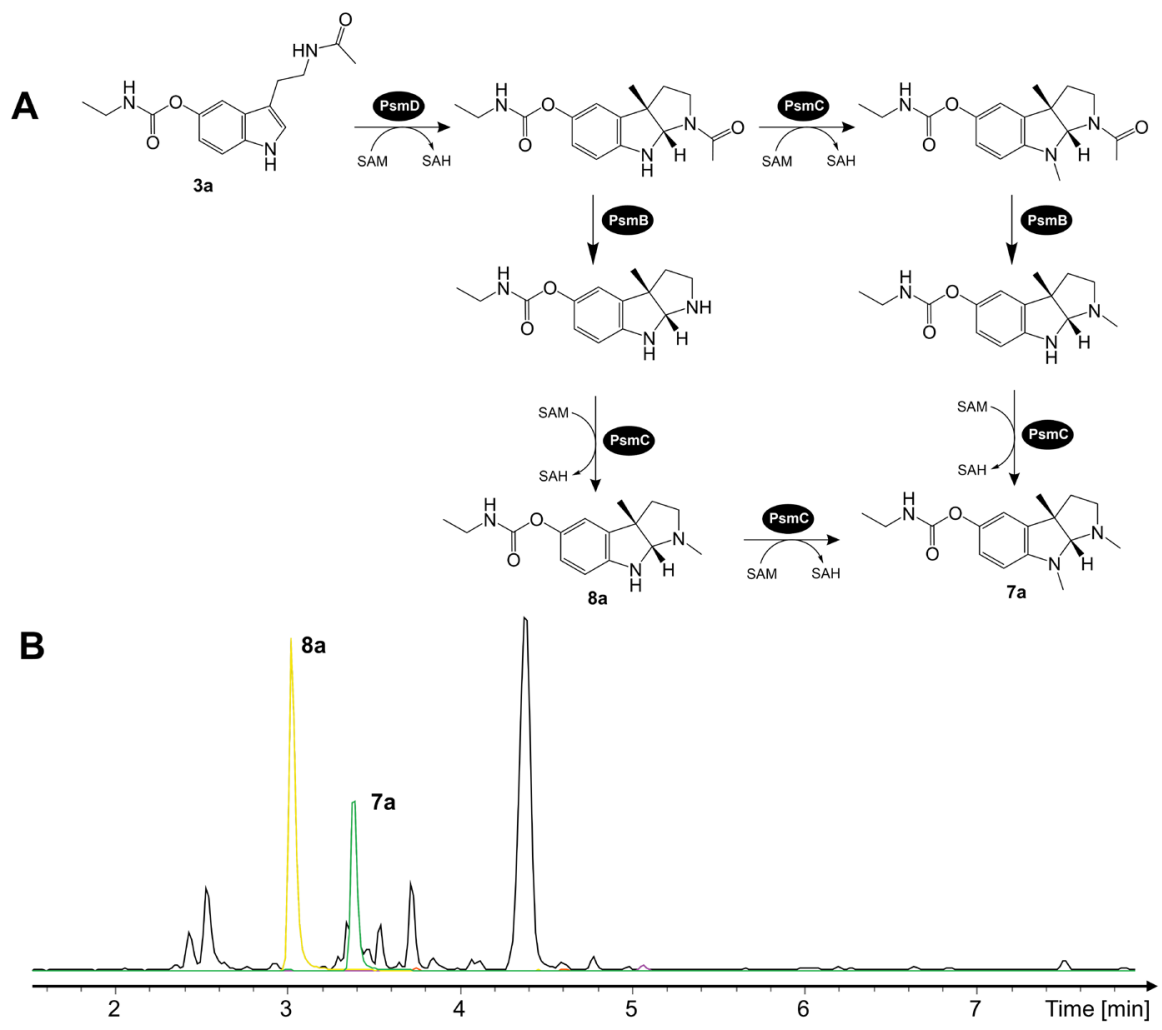

Figure S35. Proposed mutasynthetic pathways from $N$-acetyl-5-ethylcarbamoylserotonin (3a) to 7a (A). Total ion chromatogram of the raw extract from M. xanthus NM:pMEX10 fed with 3a. The EICs of 8a $(\mathrm{m} / \mathrm{z} 276.17)$ and 7a $(\mathrm{m} / z$ 290.18) are highlighted (B). 
A

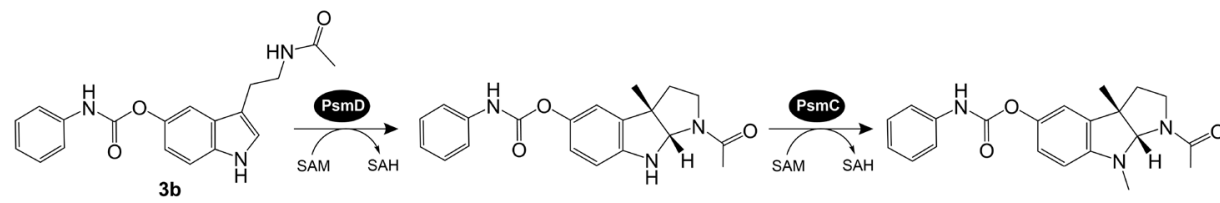

3b

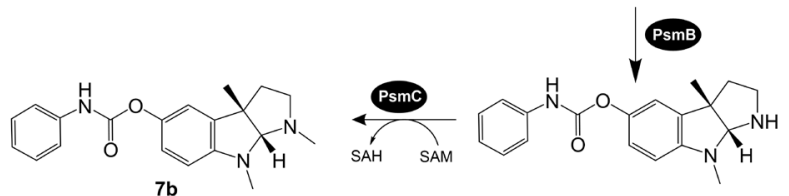

B

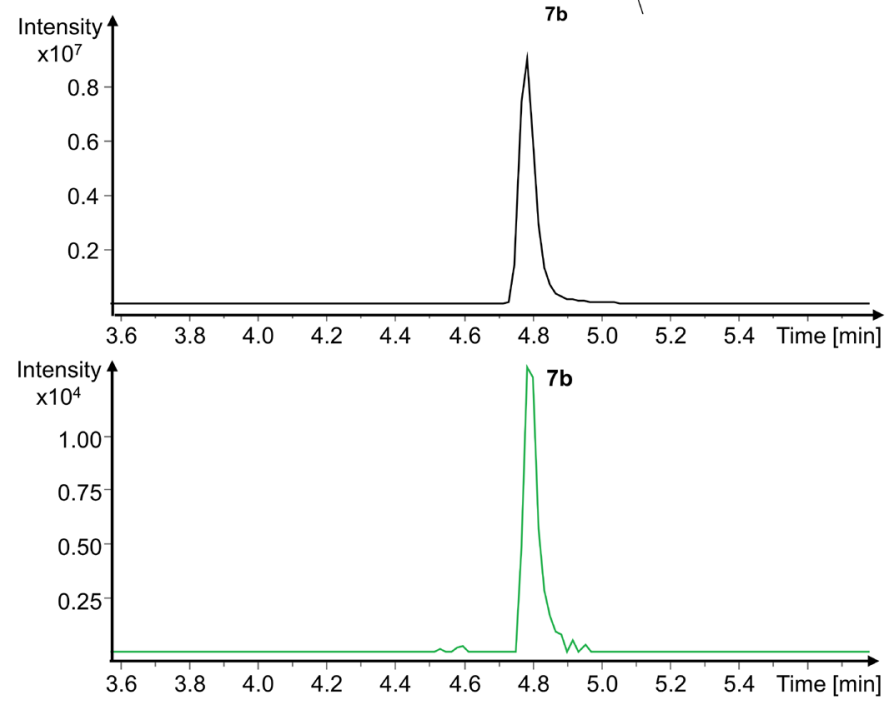

Figure S36. Proposed mutasynthetic pathway from $N$-acetyl-5-phenylcarbamoylserotonin (3b) to phenserine (7b) (A). Total ion chromatogram of $\mathbf{7 b}$ (analytical standard, Biomol) (B). EIC of 7b $(\mathrm{m} / \mathrm{z} 338.18)$ in a raw extract from M. xanthus NM:pMEX10 fed with $\mathbf{3 b}(\mathrm{m} / \mathrm{z} 338.15)(\mathbf{C})$. 


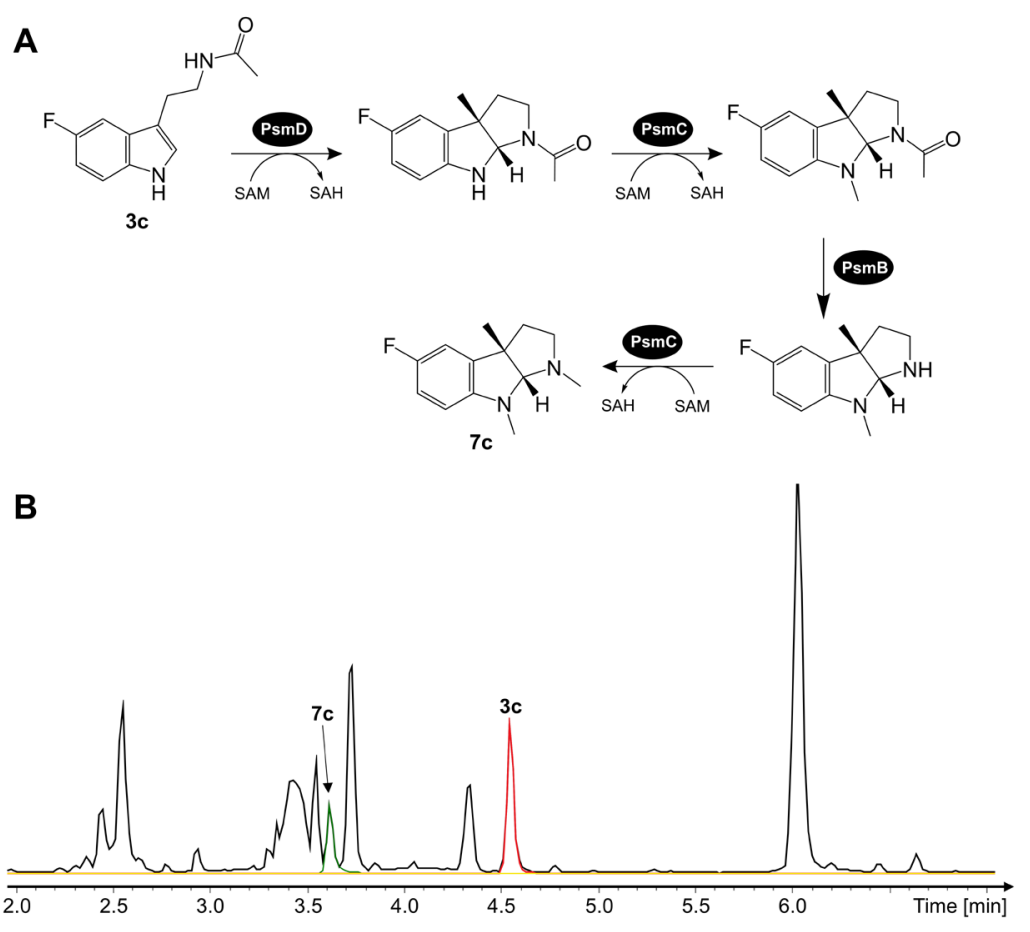

Figure S37. Proposed mutasynthetic pathway from $N$-acetyl-5-fluorotryptamine (3c) to 7c (A). Total ion chromatogram of the raw extract from $M$. xanthus NM:pMEX10 fed with 3c. The EICs of 3c $(m / z ~ 221.10)$ and 7c $(m / z ~ 221.14)$ are highlighted (B).
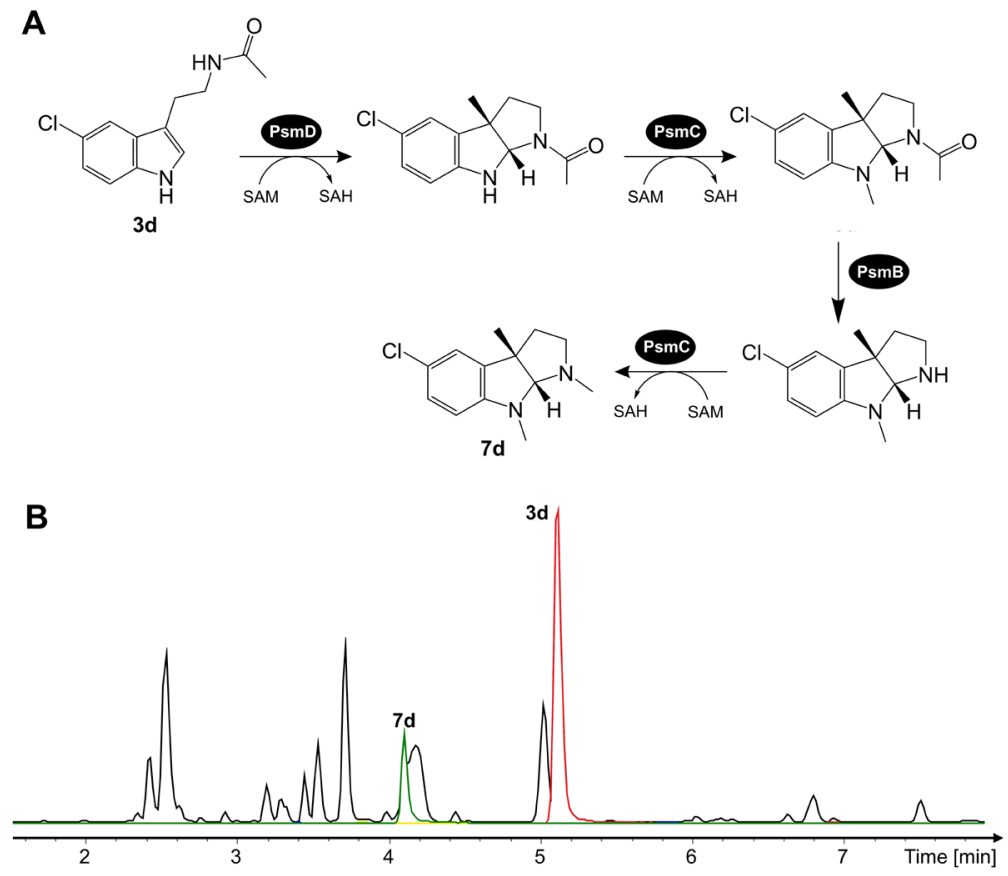

Figure S38. Proposed mutasynthetic pathway from $N$-acetyl-5-chlorotryptamine (3d) to 7d (A). Total ion chromatogram of the raw extract from M. xanthus NM:pMEX10 fed with 3d. The EICs of 3d $(\mathrm{m} / z 237.07)$ and $7 \mathbf{d}(\mathrm{m} / z$ 237.11) are highlighted $(\mathbf{B})$. 

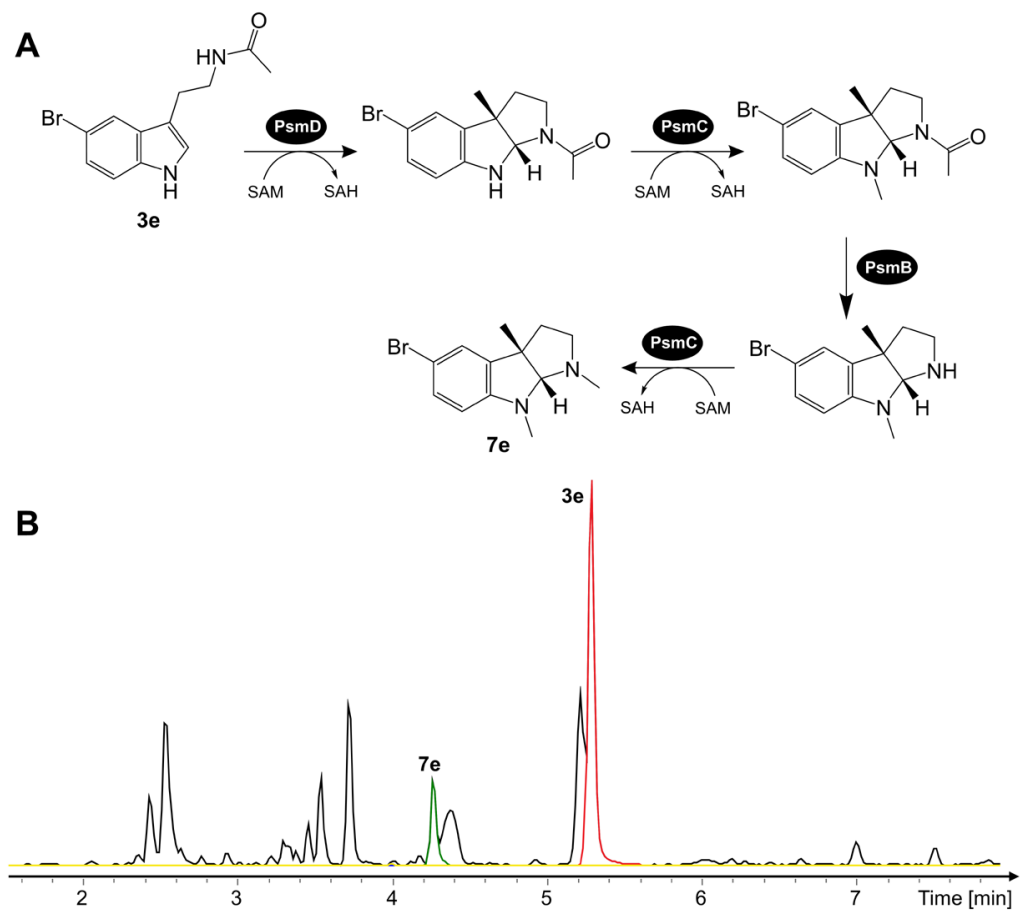

Figure S39. Proposed mutasynthetic pathway from $N$-acetyl-5-bromotryptamine (3e) to 7e (A). Total ion chromatogram of the raw extract from M. xanthus NM:pMEX10 fed with 3e. The EICs of $\mathbf{3 e}(\mathrm{m} / z 281.02)$ and $7 \mathbf{e}(\mathrm{m} / z 281.06)$ are highlighted (B).
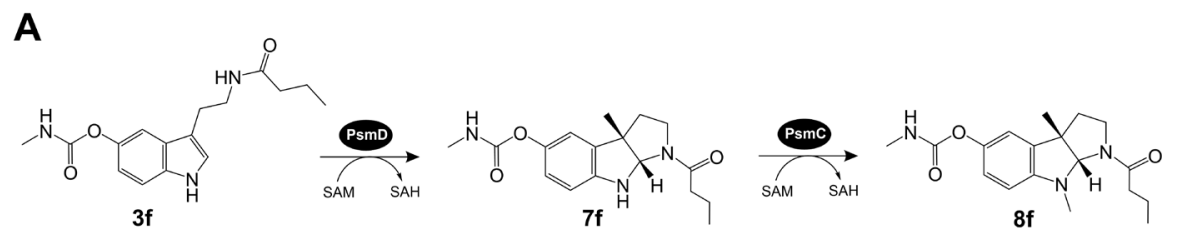

B

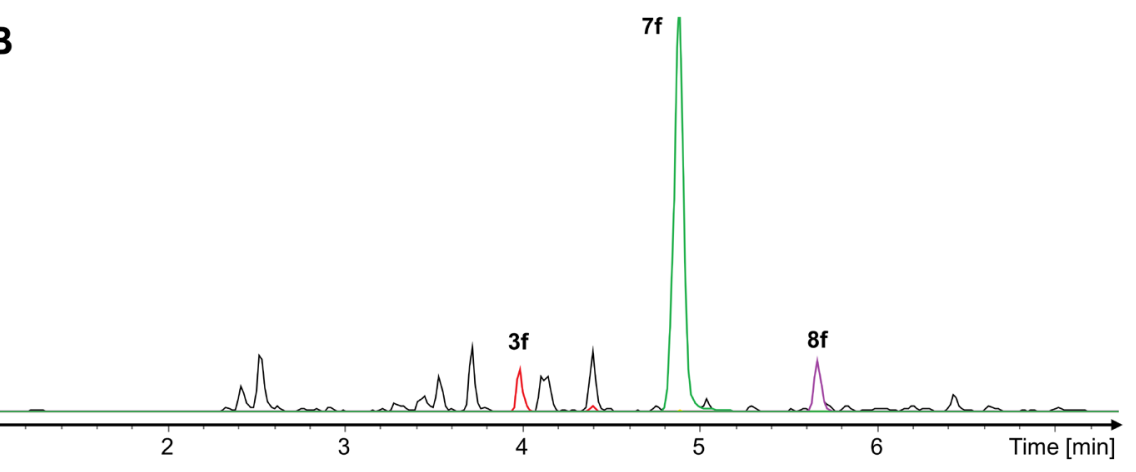

Figure S40. Proposed mutasynthetic pathway from $N$-butyryl-5-carbamoyltryptamine (3f) to $7 \mathbf{f}(\mathbf{A})$. Total ion chromatogram of the raw extract from M. xanthus NM:pMEX10 fed with $\mathbf{3 f}$. The EICs of $\mathbf{3 f}(\mathrm{m} / \mathrm{z} 304.16), \mathbf{7 f}(\mathrm{m} / z 318.18)$, and $\mathbf{8 f}(\mathrm{m} / z$ 332.19) are highlighted (B). 
Table S8. NMR data of ethyl-physostigmine (7a) in chloroform- $d$.

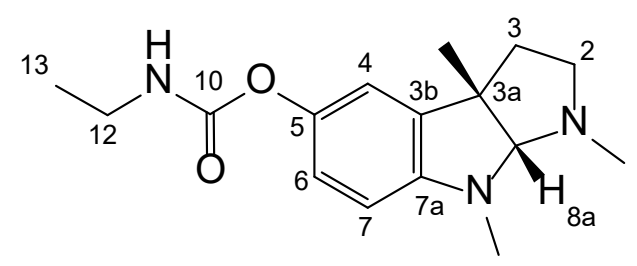

\begin{tabular}{|c|c|c|c|c|c|}
\hline$\#$ & $\delta_{\mathrm{C}}$ & type & $\delta_{\mathrm{H}}, \mathrm{M}(\mathrm{J}$ in $\mathrm{Hz})$ & COSY & $\mathrm{HMBC}\left({ }^{1} \mathrm{H} \rightarrow{ }^{13} \mathrm{C}\right)$ \\
\hline \multirow[t]{2}{*}{2} & 52.7 & $\mathrm{CH}_{2}$ & A: $3.55, \mathrm{~m}$ & 2B, 3A, (3B) & $3 a, 8 a$ \\
\hline & & & B: $2.62, \mathrm{~m}$ & $2 \mathrm{~A}, 3 \mathrm{~A}, 3 \mathrm{~B}$ & n.d. \\
\hline \multirow[t]{2}{*}{3} & 38.1 & $\mathrm{CH}_{2}$ & A: $2.36, \mathrm{~m}$ & $2 \mathrm{~A}, 2 \mathrm{~B}, 3 \mathrm{~B}$ & 3a, 3b, 3a-Me \\
\hline & & & B: $2.25, \mathrm{~m}$ & $(2 \mathrm{~A}), 2 \mathrm{~B}, 3 \mathrm{~A}$ & $3 a, 3 b, 8 a$ \\
\hline $3 a$ & 53.8 & $\mathrm{C}_{\mathrm{q}}$ & & & \\
\hline $3 b$ & 134.9 & $\mathrm{C}_{\mathrm{q}}$ & & & \\
\hline 4 & 116.5 & $\mathrm{CH}$ & $6.85, \mathrm{~d}(2.3)$ & 6 & $3 a, 5,6,7 a$ \\
\hline 5 & 145.4 & $\mathrm{C}_{\mathrm{q}}$ & & & \\
\hline 6 & 122.3 & $\mathrm{CH}$ & $6.93, \mathrm{dd}(8.5,2.3)$ & 4,7 & $4,(5), 7 \mathrm{a}$ \\
\hline 7 & 108.9 & $\mathrm{CH}$ & $6.56, \mathrm{~d}(8.5)$ & 6 & $3 b, 5$ \\
\hline $7 \mathrm{a}$ & 147.4 & $\mathrm{C}_{\mathrm{q}}$ & & & \\
\hline $8 \mathrm{a}$ & 95.3 & $\mathrm{CH}$ & $5.13, \mathrm{~s}$ & & $2,3,3 \mathrm{~b}, 7 \mathrm{a}, 3 \mathrm{a}-\mathrm{Me}, 8-\mathrm{Me}$ \\
\hline 10 & 154.9 & $\mathrm{C}_{\mathrm{q}}$ & & & \\
\hline 12 & 36.2 & $\mathrm{CH}_{2}$ & $3.28, \mathrm{q}(7.2)$ & 13 & 10,13 \\
\hline 13 & 15.1 & $\mathrm{CH}_{3}$ & $1.19, \mathrm{t}(7.2)$ & 12 & 12 \\
\hline 1-Me & 33.9 & $\mathrm{CH}_{3}$ & $2.74, \mathrm{~s}$ & & $2,8 \mathrm{a}$ \\
\hline 3a-Me & 25.8 & $\mathrm{CH}_{3}$ & $1.50, \mathrm{~s}$ & & $3,3 a, 3 b, 8 a$ \\
\hline 8-Me & 38.2 & $\mathrm{CH}_{3}$ & $3.09, \mathrm{~s}$ & & $7 \mathrm{a}, 8 \mathrm{a}$ \\
\hline
\end{tabular}




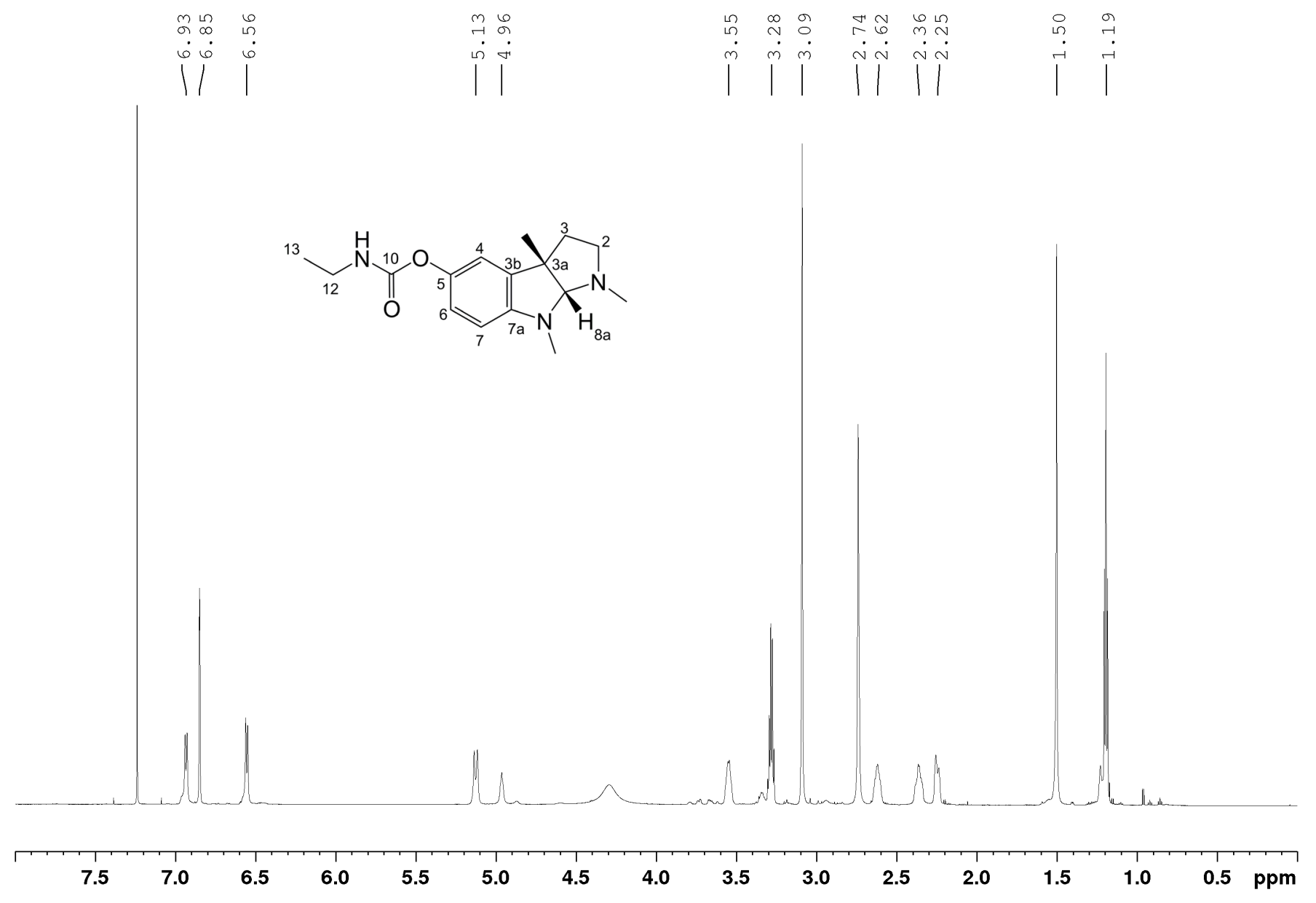

Figure S41. ${ }^{1} \mathrm{H}$ NMR spectrum $(700 \mathrm{MHz})$ of ethyl-physostigmine (7a) in chloroform- $d$. 
|
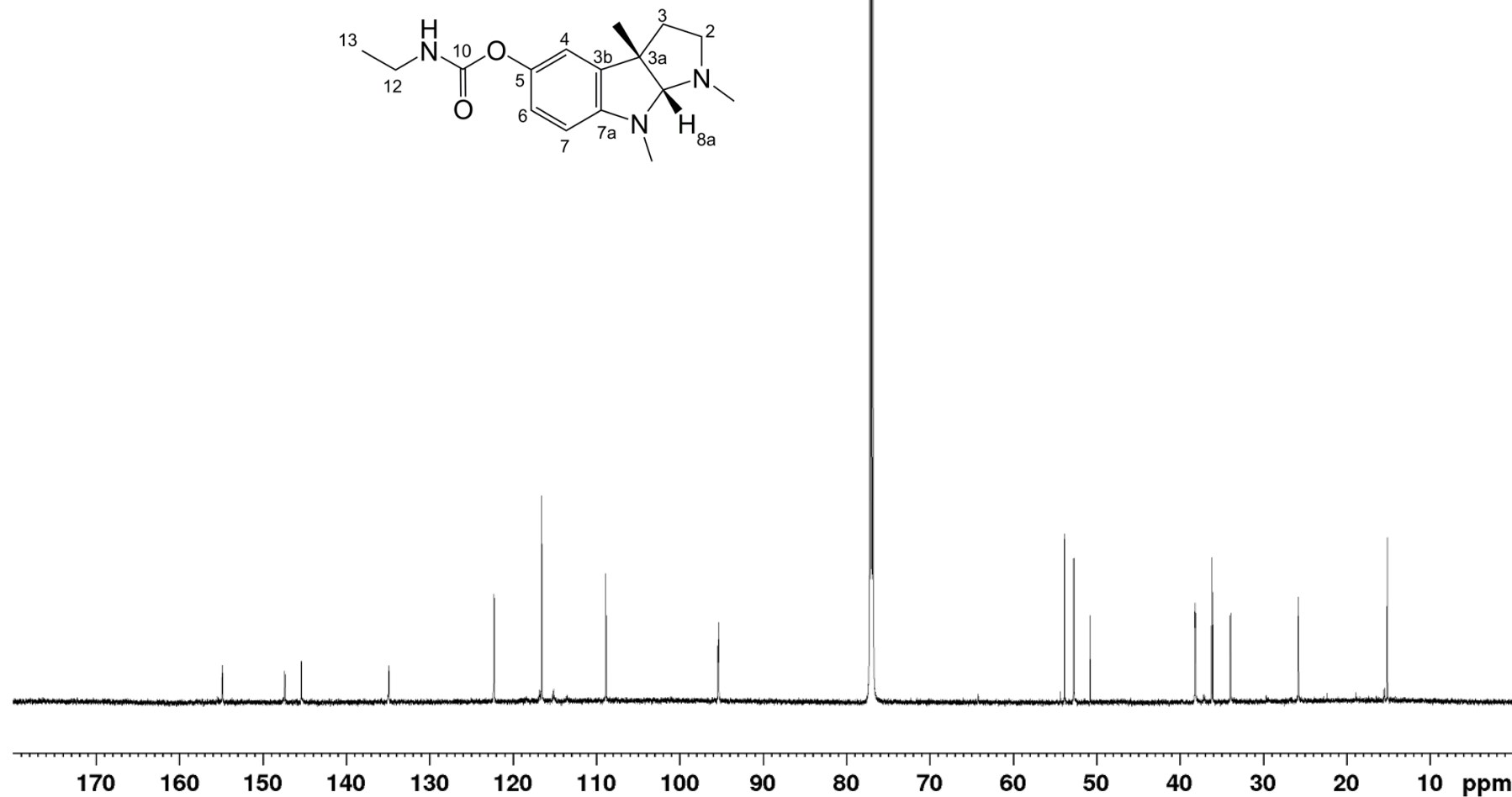

Figure S42. ${ }^{1} \mathrm{H}$-decoupled ${ }^{13} \mathrm{C}$ NMR spectrum $(175 \mathrm{MHz})$ of ethyl-physostigmine (7a) in chloroform- $d$. 


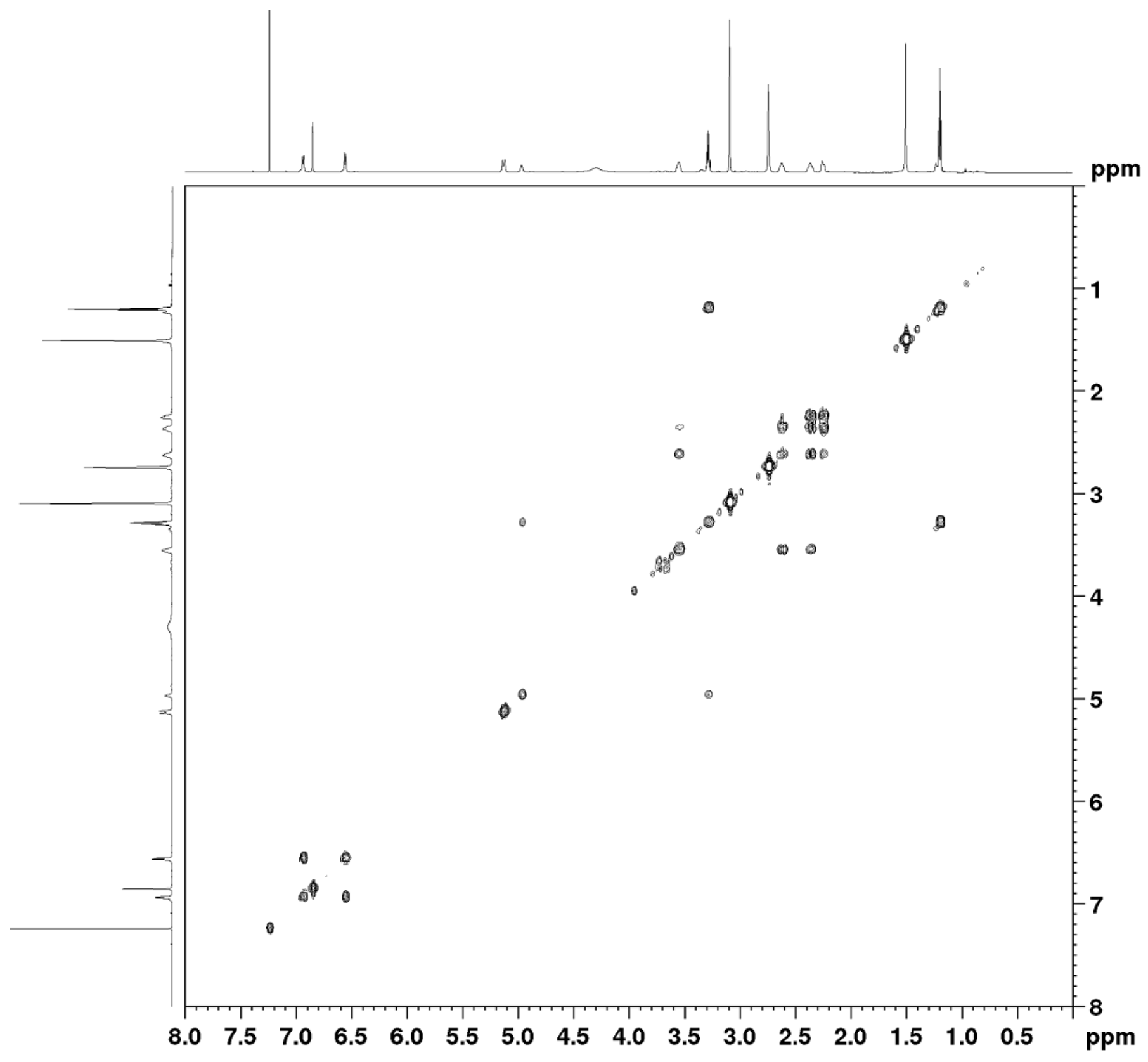

Figure S43. COSY spectrum of ethyl-physostigmine (7a) in chloroform- $d$. 


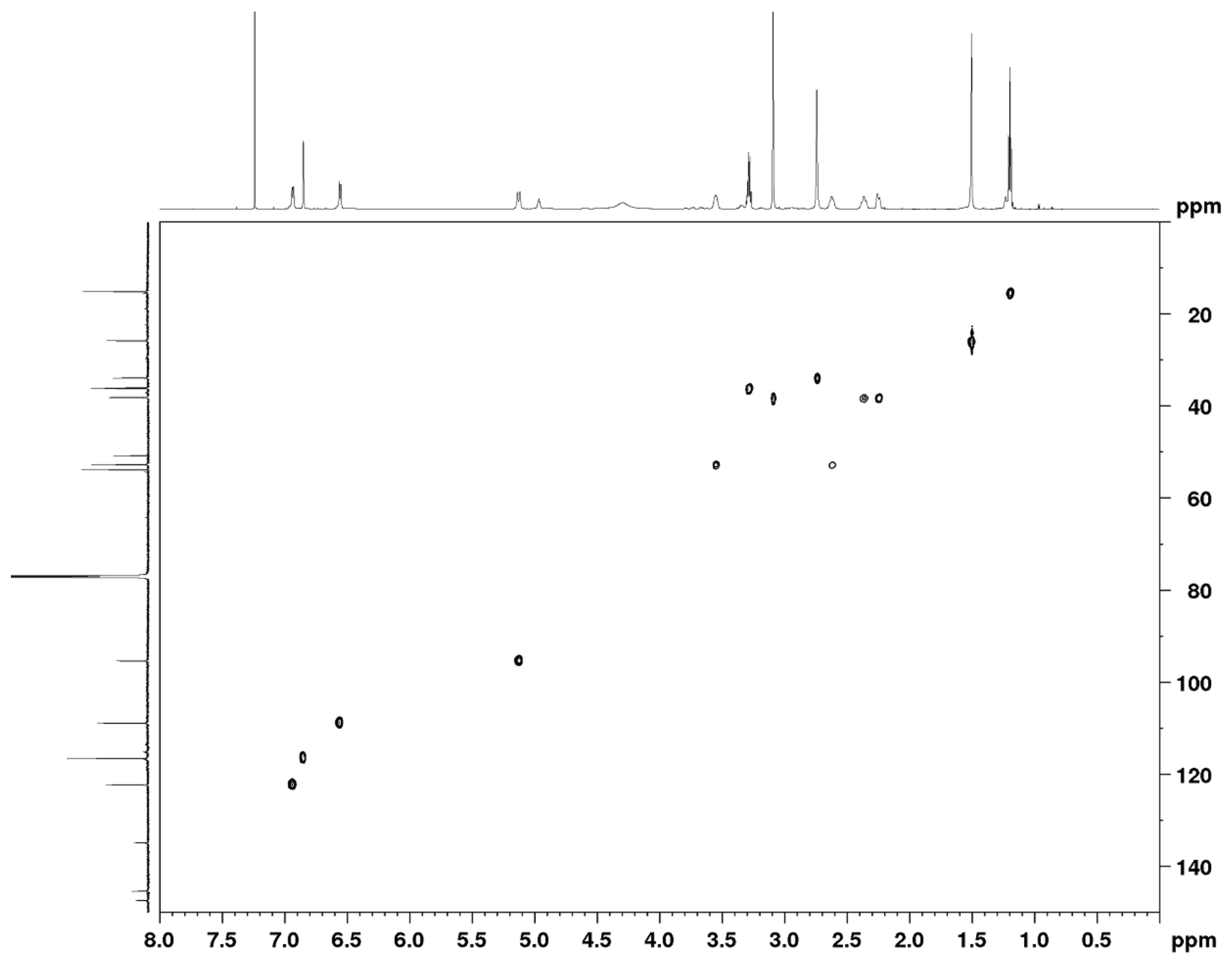

Figure S44. HSQC spectrum of ethyl-physostigmine (7a) in chloroform- $d$. 


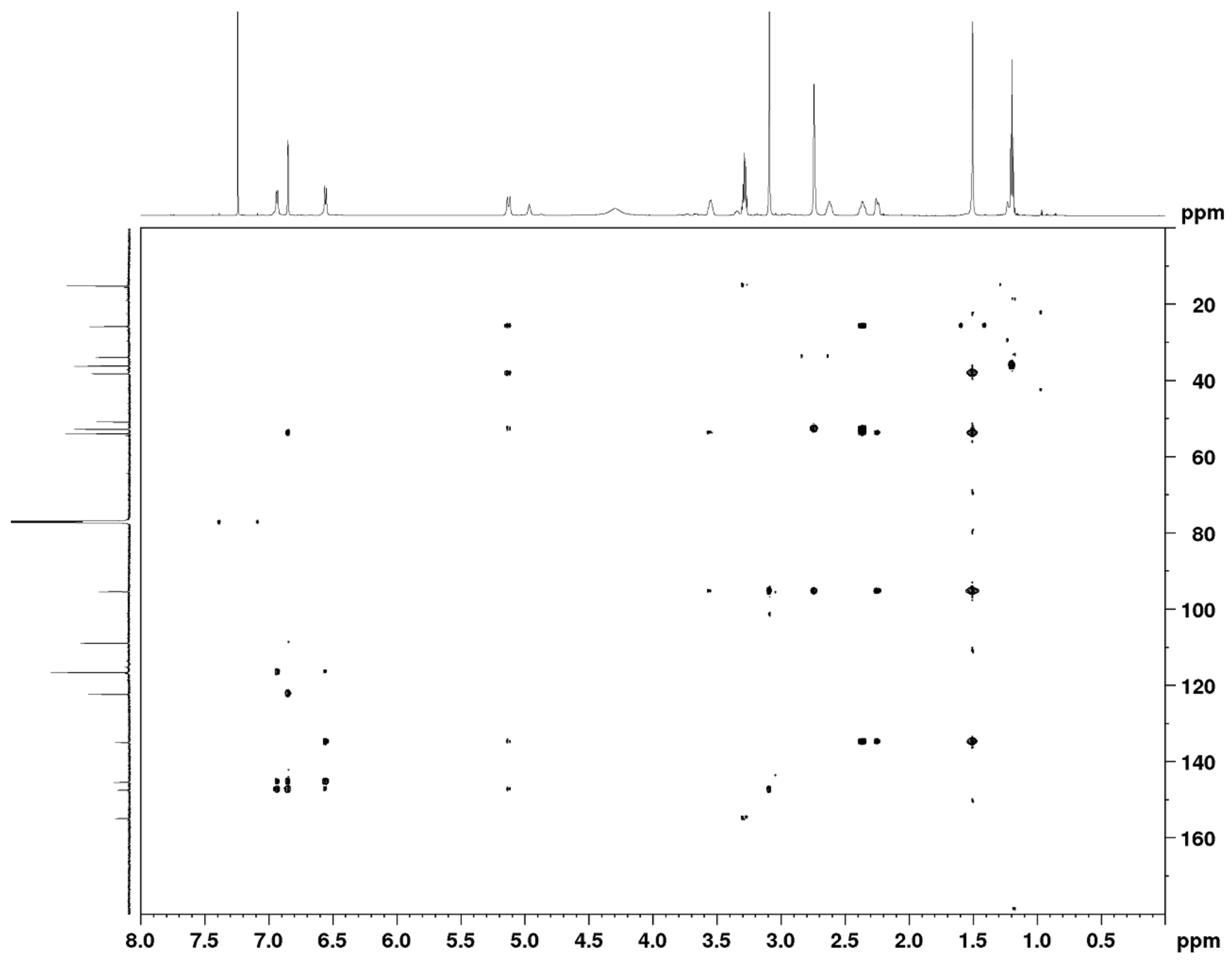

Figure S45. HMBC spectrum of ethyl-physostigmine (7a) in chloroform- $d$. 
Table S9. NMR data of 8-desmethyl-ethyl-physostigmine (8a) in chloroform- $d$.

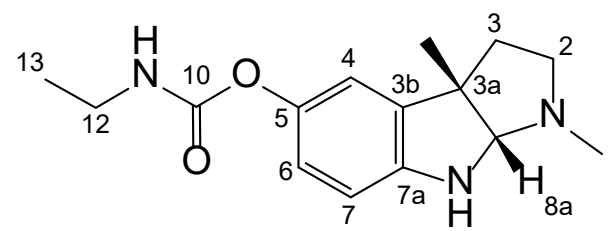

\begin{tabular}{|c|c|c|c|c|c|}
\hline \# & $\delta_{\mathrm{C}}$ & type & $\delta_{\mathrm{H}}, \mathrm{M}(J$ in $\mathrm{Hz})$ & $\mathrm{COSY}$ & HMBC $\left({ }^{1} \mathrm{H} \rightarrow{ }^{13} \mathrm{C}\right)$ \\
\hline \multirow[t]{2}{*}{2} & $52.3, \mathrm{~s}$ & $\mathrm{CH}_{2}$ & A: $3.48, \mathrm{~m}$ & $2 \mathrm{~B}, 3 \mathrm{~A},(3 \mathrm{~B})$ & $3 a, 8 a$ \\
\hline & & & B: $2.62, \mathrm{~m}$ & $2 \mathrm{~A}, 3 \mathrm{~A}, 3 \mathrm{~B}$ & n.d. \\
\hline \multirow[t]{2}{*}{3} & $38.7, \mathrm{~s}$ & $\mathrm{CH}_{2}$ & $\mathrm{~A}: 2.34, \mathrm{dt}(13.3,6.2)$ & $2 \mathrm{~A}, 2 \mathrm{~B}, 3 \mathrm{~B}$ & $2,3 \mathrm{a}, 3 \mathrm{~b}, 3 \mathrm{a}-\mathrm{Me}$ \\
\hline & & & B: 2.23, dd $(13.3,5.6)$ & $(2 \mathrm{~A}), 2 \mathrm{~B}, 3 \mathrm{~A}$ & $3 a, 3 b, 8 a$ \\
\hline $3 a$ & $54.6, \mathrm{~s}$ & $\mathrm{C}_{\mathrm{q}}$ & & & \\
\hline $3 b$ & $134.8, \mathrm{~s}$ & $\mathrm{C}_{\mathrm{q}}$ & & & \\
\hline 4 & $116.6, \mathrm{~s}$ & $\mathrm{CH}$ & $6.85, \mathrm{~m}$ & 6 & $3 a, 6,7 a$ \\
\hline 5 & $145.5, \mathrm{~s}$ & $\mathrm{C}_{\mathrm{q}}$ & & & \\
\hline 6 & 122.1, s & $\mathrm{CH}$ & $6.85, \mathrm{~m}$ & 4,7 & 4 \\
\hline 7 & $110.4, \mathrm{~s}$ & $\mathrm{CH}$ & $6.67, \mathrm{~d}(9.1)$ & 6 & $3 b, 5$ \\
\hline $7 \mathrm{a}$ & $145.0, \mathrm{~s}$ & $\mathrm{C}_{\mathrm{q}}$ & & & \\
\hline $8 \mathrm{a}$ & $88.0, \mathrm{~s}$ & $\mathrm{CH}$ & $5.39, \mathrm{~s}$ & & 2, 3a-Me, 7a \\
\hline \multirow[t]{2}{*}{10} & $154.9, \mathrm{~s}$ & $\mathrm{C}_{\mathrm{q}}$ & & & \\
\hline & & $\mathrm{NH}$ & $4.96, \mathrm{t}(5.8)$ & 12 & n.d. \\
\hline 12 & $36.2, \mathrm{~s}$ & $\mathrm{CH}_{2}$ & $3.28, \mathrm{dq}(7.2,5.8)$ & 11,13 & 10,13 \\
\hline 13 & 15.1, s & $\mathrm{CH}_{3}$ & $1.19, \mathrm{t}(7.2)$ & 12 & 12 \\
\hline 1-Me & $33.5, \mathrm{~s}$ & $\mathrm{CH}_{3}$ & $2.71, \mathrm{~s}$ & & $2,8 \mathrm{a}$ \\
\hline 3a-Me & $25.4, \mathrm{~s}$ & $\mathrm{CH}_{3}$ & $1.50, \mathrm{~s}$ & & $3,3 a, 3 b, 8 a$ \\
\hline
\end{tabular}




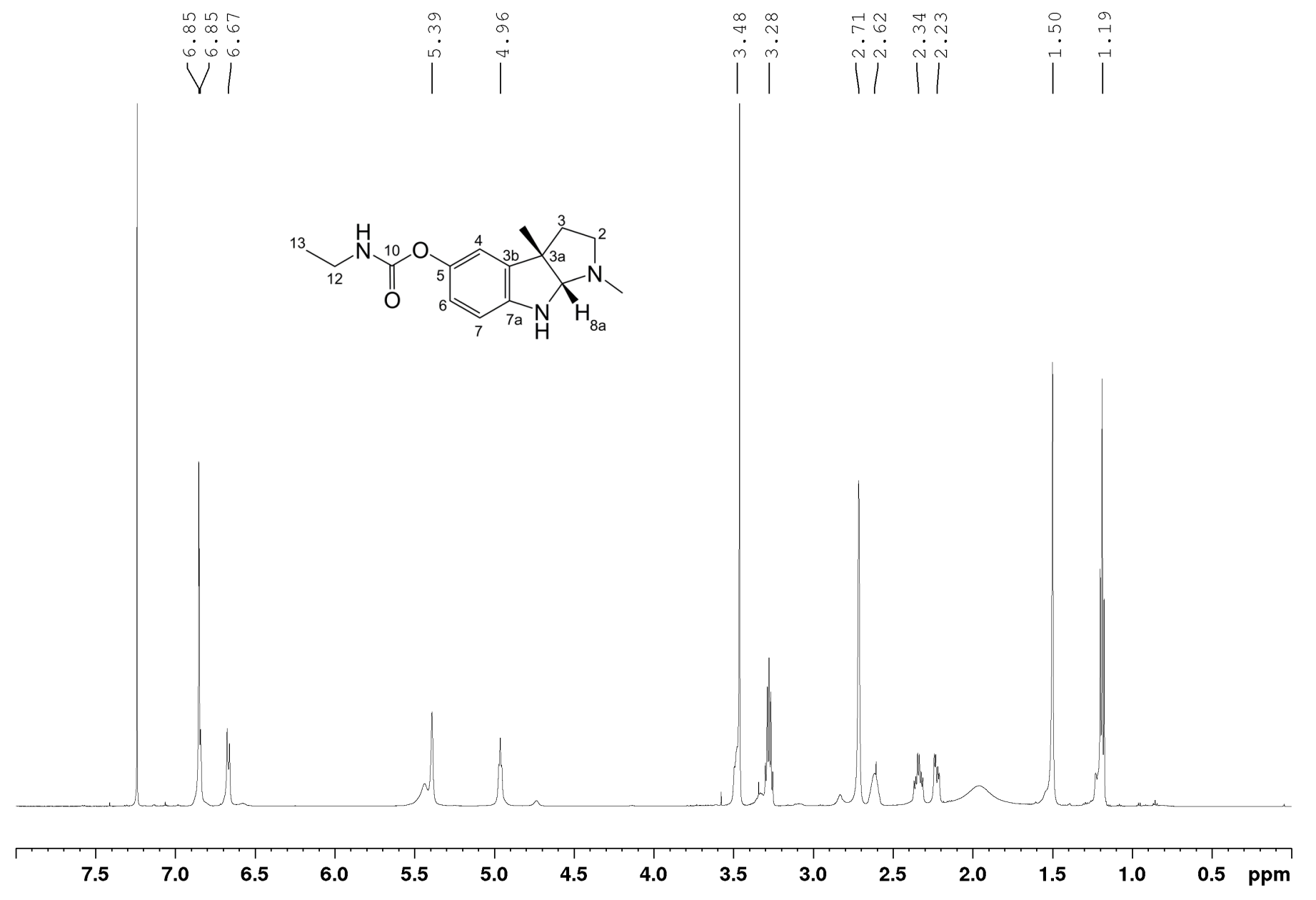

Figure S46. ${ }^{1} \mathrm{H}$ NMR spectrum (600 MHz) of 8-desmethyl-ethyl-physostigmine (8a) in chloroform- $d$. 


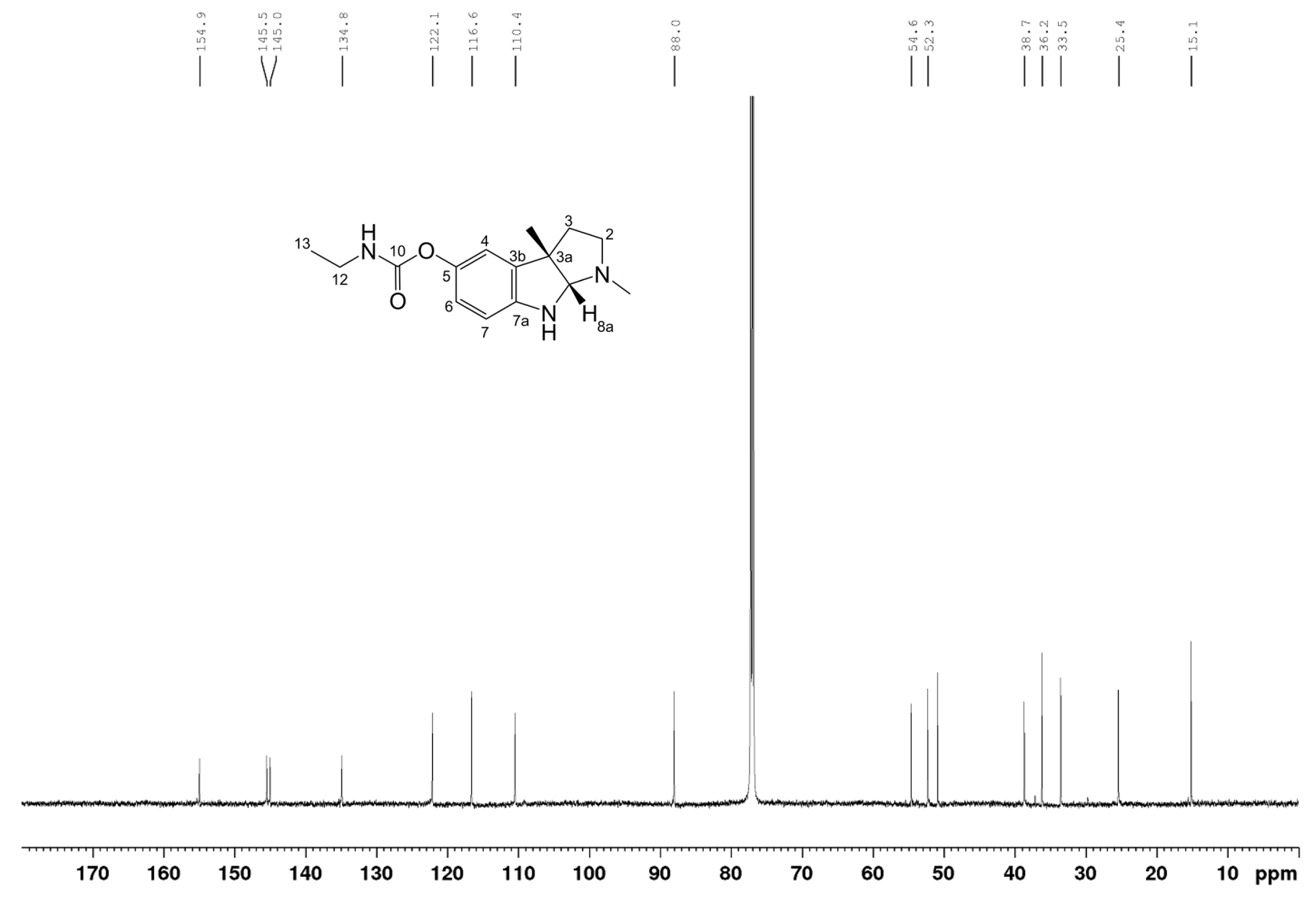

Figure S47. ${ }^{1} \mathrm{H}$-decoupled ${ }^{13} \mathrm{C}$ NMR spectrum $(150 \mathrm{MHz})$ of 8-des methyl-ethyl-physostigmine (8a) in chloroform- $d$. 


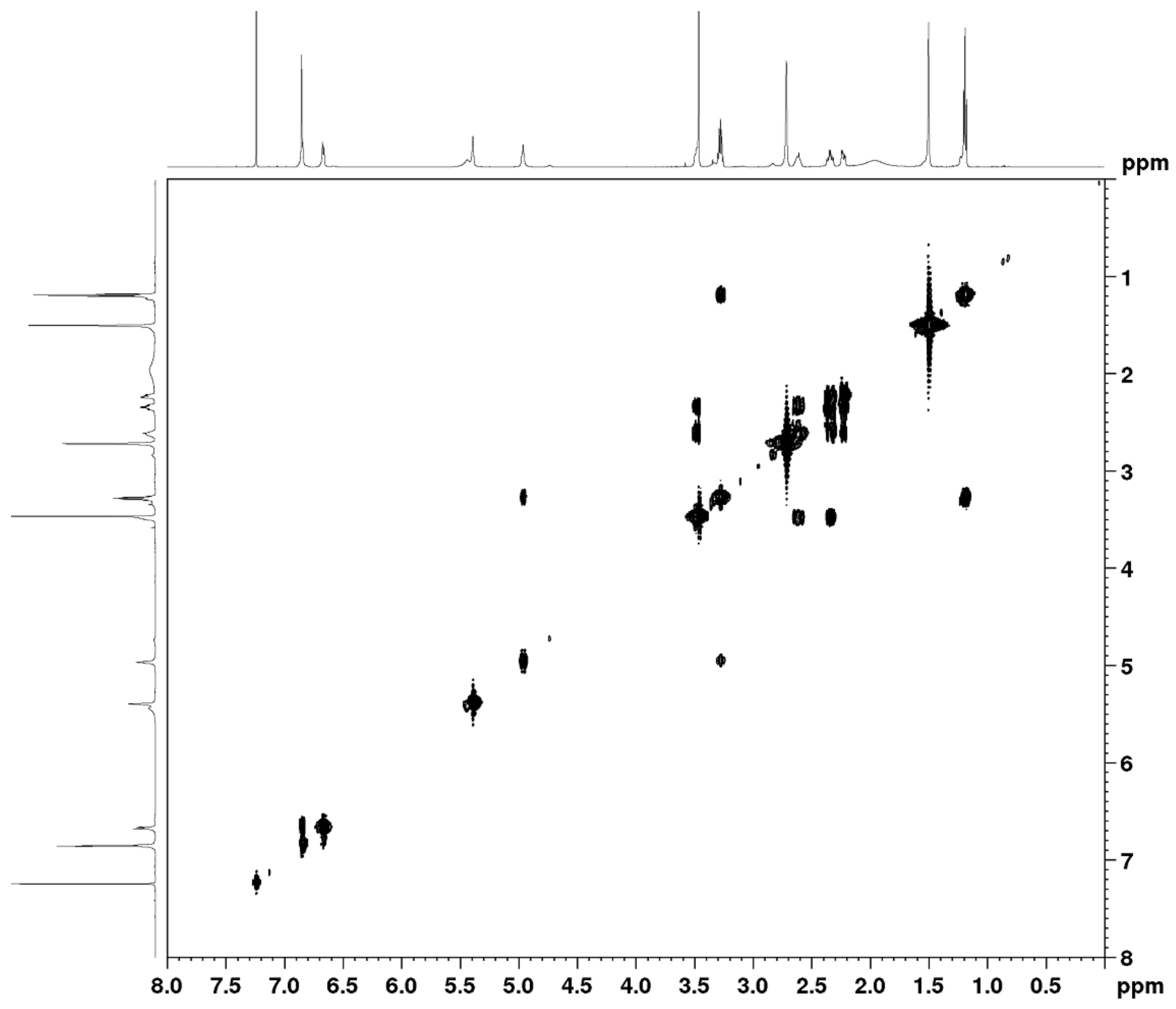

Figure S48. COSY spectrum of 8-desmethyl-ethyl-physostigmine (8a) in chloroform- $d$. 


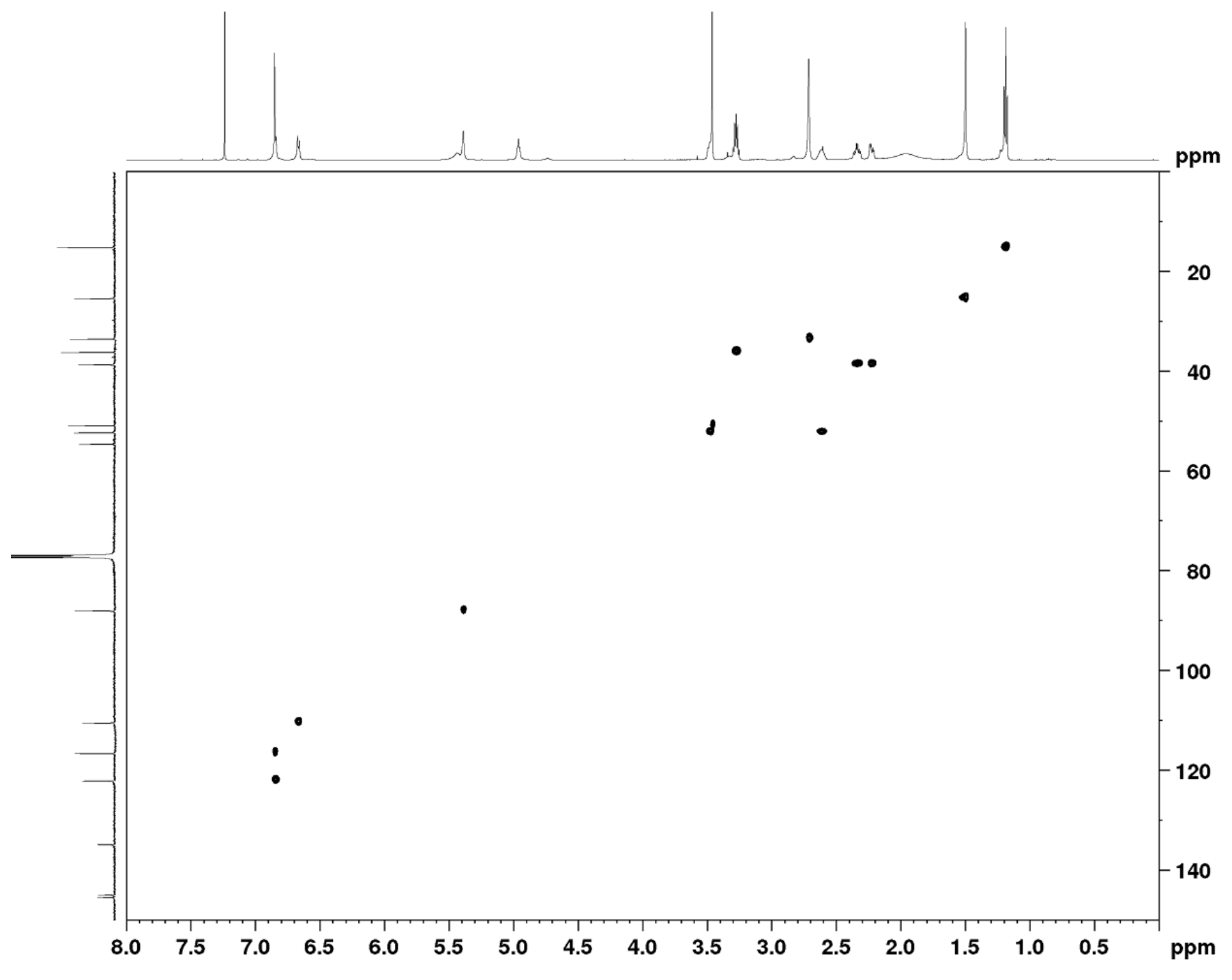

Figure S49. HSQC spectrum of 8-des methyl-ethyl-physostigmine (8a) in chloroform- $d$. 


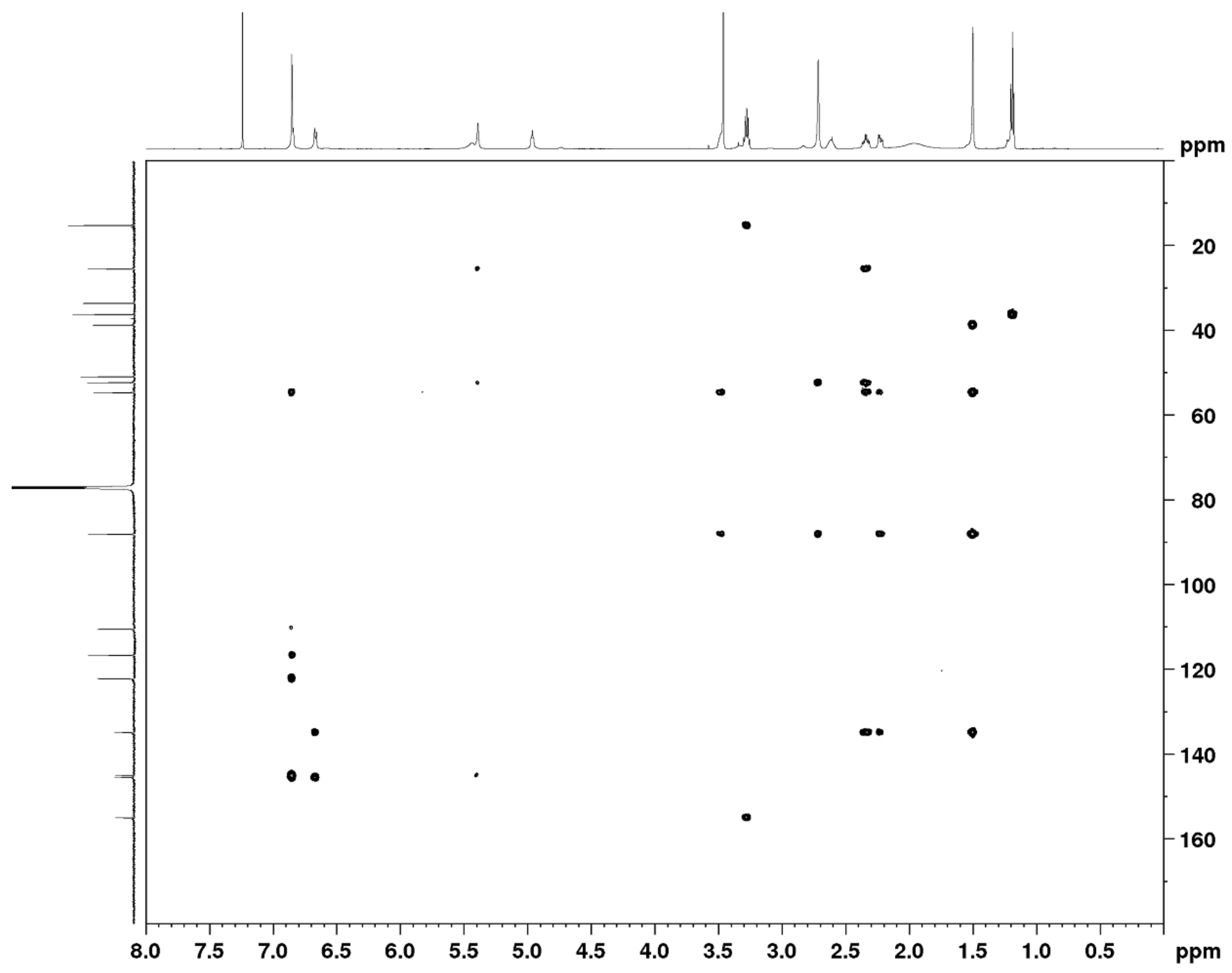

Figure S50. HMBC spectrum of 8-desmethyl-ethyl-physostigmine (8a) in chloroform- $d$. 
Table S10. NMR data of fluorophysostigmine (7c) in chloroform- $d$.

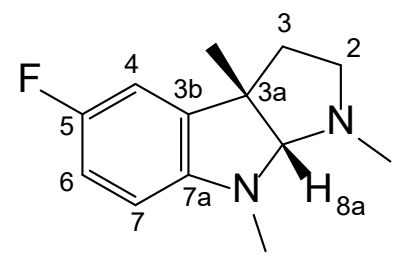

\begin{tabular}{|c|c|c|c|c|c|}
\hline \# & $\delta_{\mathrm{C}}, \mathrm{M}(\mathrm{J}$ in $\mathrm{Hz})$ & type & $\delta_{\mathrm{H}}, \mathrm{M}(\mathrm{J}$ in $\mathrm{Hz})$ & $\mathrm{COSY}$ & HMBC $\left({ }^{1} \mathrm{H} \rightarrow{ }^{13} \mathrm{C}\right)$ \\
\hline \multirow[t]{2}{*}{2} & $52.8, \mathrm{~s}$ & $\mathrm{CH}_{2}$ & A: $3.61, m$ & $2 \mathrm{~B}, 3 \mathrm{~A},(3 \mathrm{~B})$ & n.d. \\
\hline & & & B: $2.59, \mathrm{~m}$ & $2 \mathrm{~A}, 3 \mathrm{~A}, 3 \mathrm{~B}$ & n.d. \\
\hline \multirow[t]{2}{*}{3} & $38.2, \mathrm{~s}$ & $\mathrm{CH}_{2}$ & A: $2.37, \mathrm{dt}(13.3,6.4)$ & $2 \mathrm{~A}, 2 \mathrm{~B}, 3 \mathrm{~B}$ & $3 a, 3 b, 3 a-M e$ \\
\hline & & & B: $2.24, \mathrm{dd}(13.3,5.8)$ & $(2 \mathrm{~A}), 2 \mathrm{~B}, 3 \mathrm{~A}$ & $3 a, 3 b, 8 a$ \\
\hline $3 a$ & $53.1^{a}$ & $\mathrm{C}_{\mathrm{q}}$ & & & \\
\hline $3 b$ & $135.5^{a}$ & $\mathrm{C}_{\mathrm{q}}$ & & & \\
\hline 4 & $110.2, \mathrm{~d}(24.7)$ & $\mathrm{CH}$ & $6.79, \mathrm{dd}(8.0,2.6)$ & 6 & $(5), 6,7 \mathrm{a}$ \\
\hline 5 & $157.6^{a}$ & $\mathrm{C}_{\mathrm{q}}$ & & & \\
\hline 6 & 115.6, d (23.6) & $\mathrm{CH}$ & $6.90, \mathrm{dt}(8.8,2.6)$ & 4,7 & $4,(5), 7 \mathrm{a}$ \\
\hline 7 & 109.4, d (8.1) & $\mathrm{CH}$ & $6.54, \mathrm{dd}(8.8,4.1)$ & 6 & $3 b, 5$ \\
\hline $7 \mathrm{a}$ & $146.0^{a}$ & $\mathrm{C}_{\mathrm{q}}$ & & & \\
\hline $8 a$ & $95.7, \mathrm{~s}$ & $\mathrm{CH}$ & $5.15, \mathrm{~s}$ & & n.d. \\
\hline 1-Me & $34.0, \mathrm{~s}$ & $\mathrm{CH}_{3}$ & 2.77, s & & $2,8 \mathrm{a}$ \\
\hline 3a-Me & 25.7, s & $\mathrm{CH}_{3}$ & $1.51, \mathrm{~s}$ & & $3,3 a, 3 b, 8 a$ \\
\hline 8-Me & $38.4, \mathrm{~s}$ & $\mathrm{CH}_{3}$ & $3.10, \mathrm{~s}$ & & $7 \mathrm{a}, 8 \mathrm{a}$ \\
\hline
\end{tabular}

${ }^{a}$ chemical shifts were deduced from the HMBC spectrum 


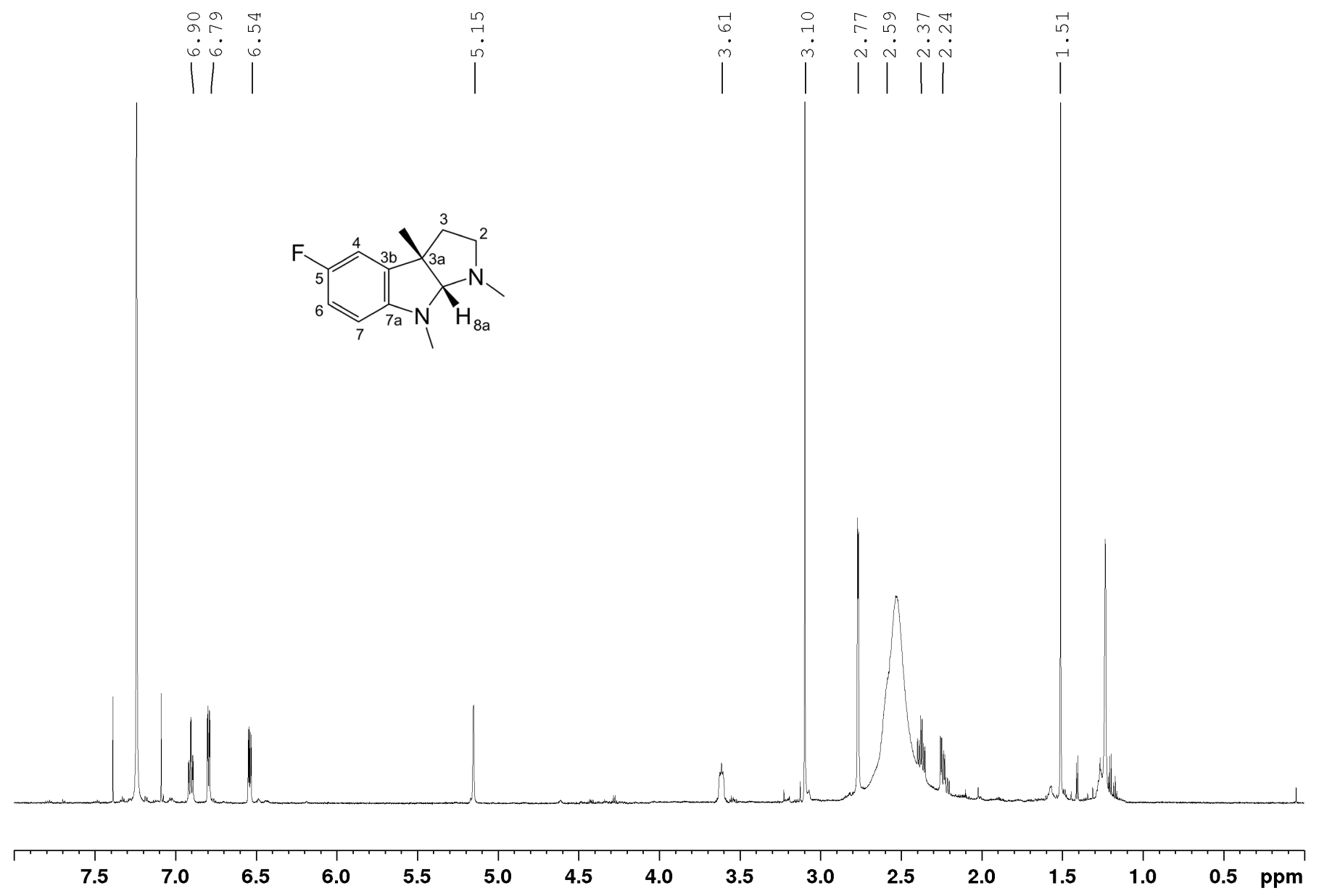

Figure S51. ${ }^{1} \mathrm{H}$ NMR spectrum $(700 \mathrm{MHz})$ of fluorophys ostigmine (7c) in chloroform- $d$. 


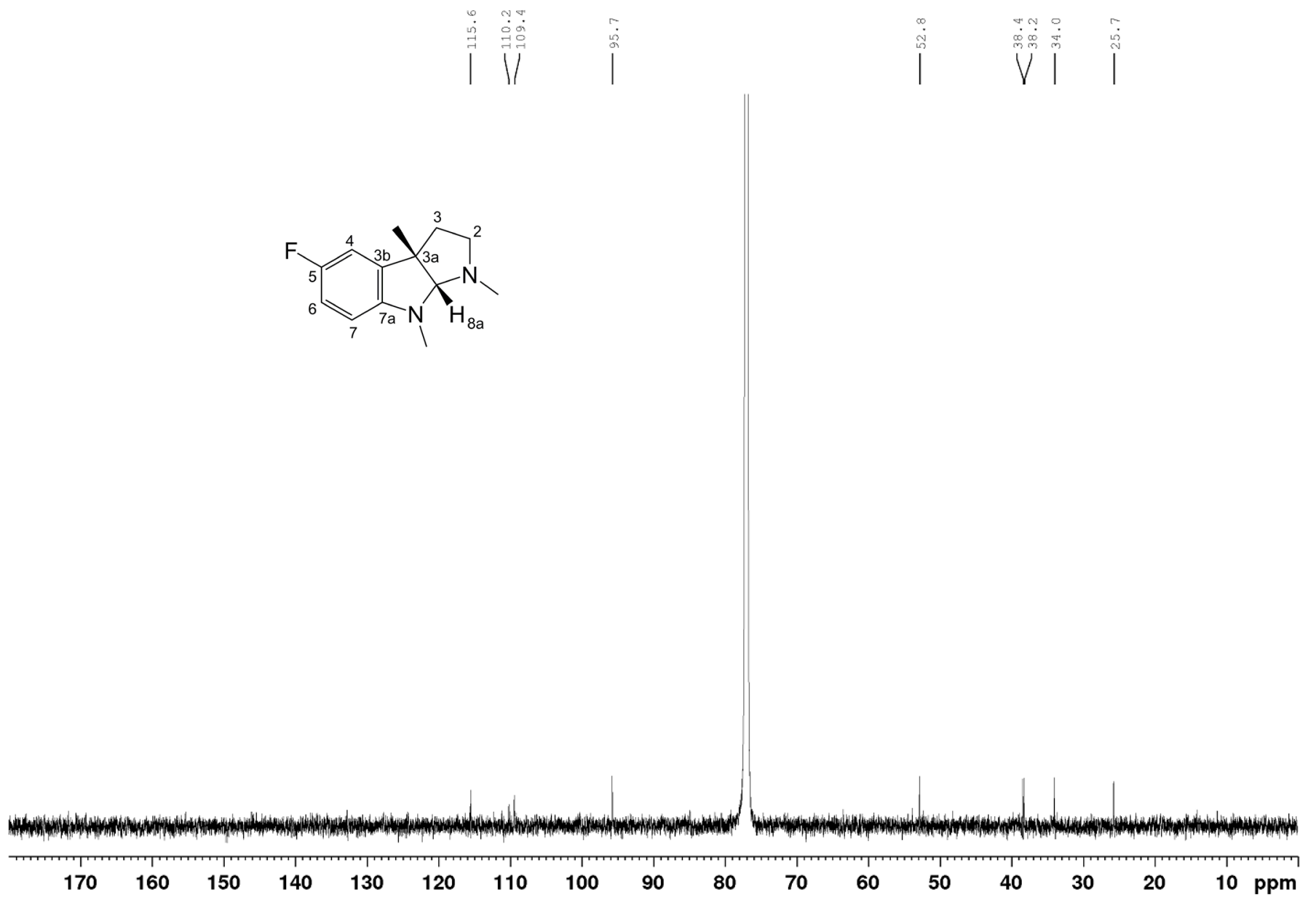

Figure S52. ${ }^{1} \mathrm{H}$-decoupled ${ }^{13} \mathrm{C}$ NMR spectrum $(175 \mathrm{MHz})$ of fluorophysostigmine (7c) in chloroform- $d$. 


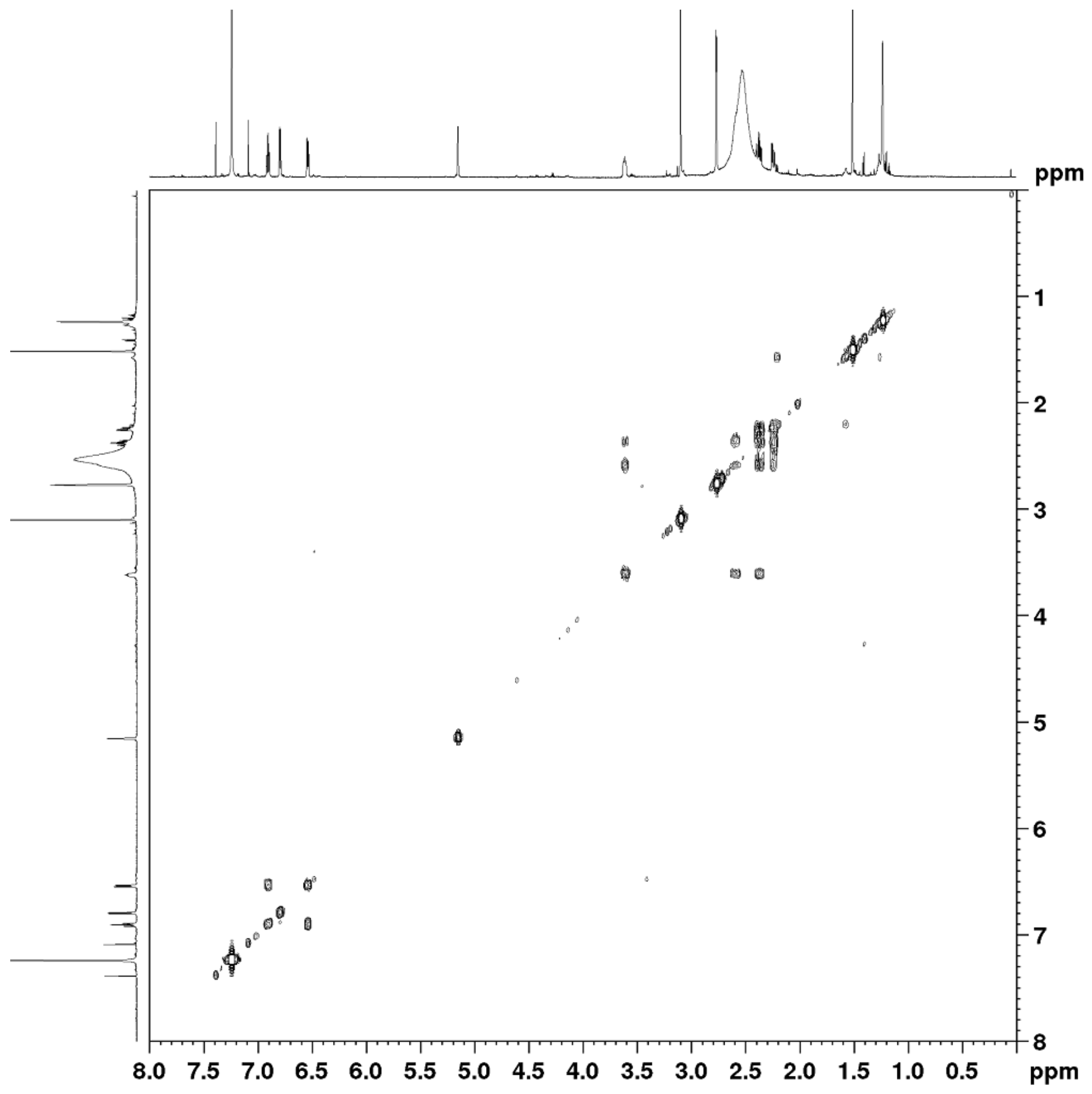

Figure S53. COSY spectrum of fluorophys ostigmine (7c) in chloroform- $d$. 


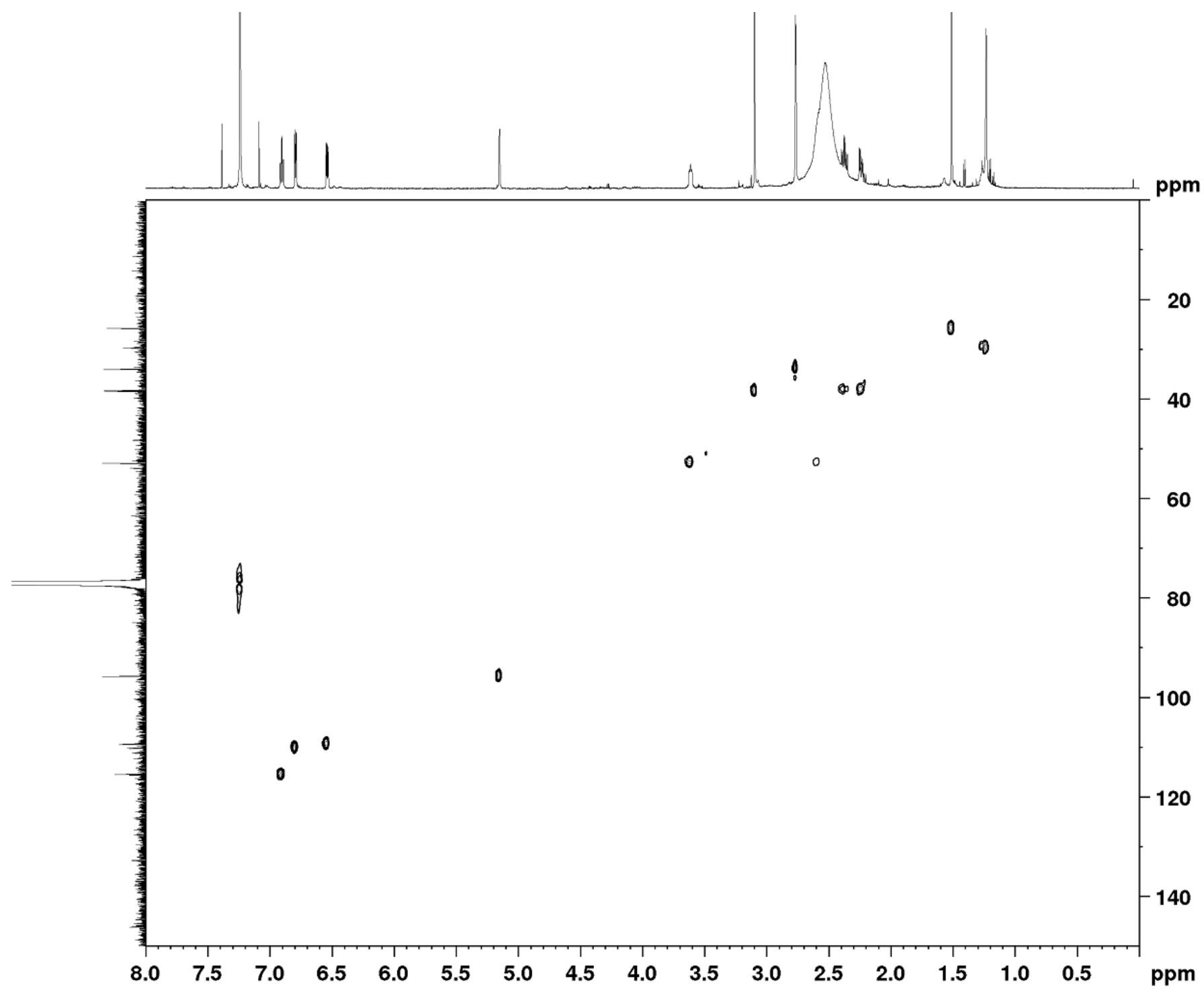

Figure S54. HSQC spectrum of fluorophysostigmine (7c) in chloroform- $d$. 


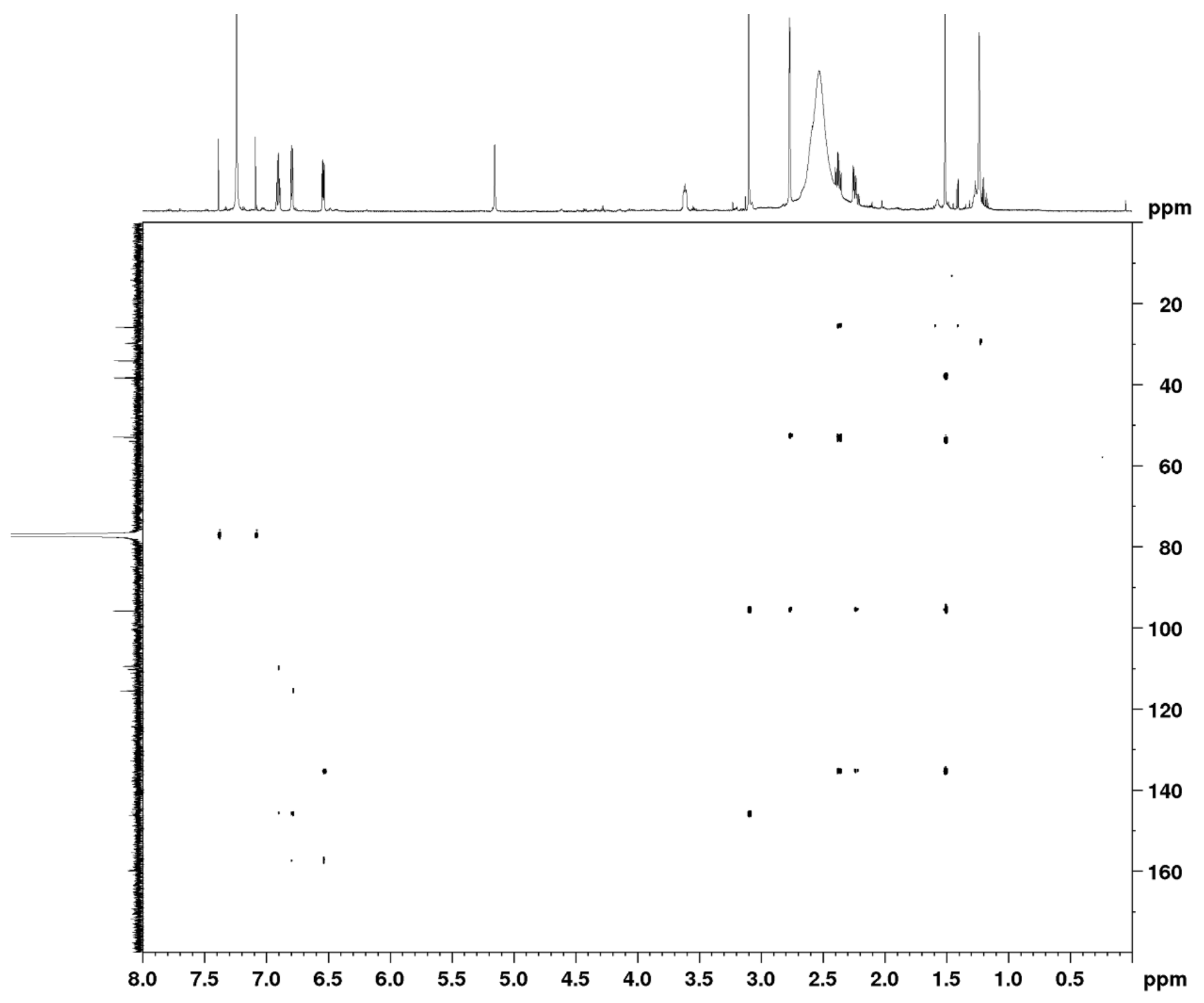

Figure S55. HMBC spectrum of fluorophysostigmine (7c) in chloroform- $d$. 
Table S11. NMR data of chlorophysostigmine (7d) in chloroform- $d$.

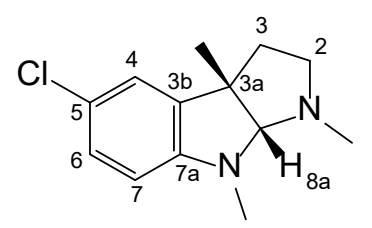

\begin{tabular}{|c|c|c|c|c|c|}
\hline$\#$ & $\delta_{\mathrm{C}}$ & type & $\delta_{\mathrm{H}}, \mathrm{M}(\mathrm{J}$ in $\mathrm{Hz})$ & COSY & HMBC $\left({ }^{1} \mathrm{H} \rightarrow{ }^{13} \mathrm{C}\right)$ \\
\hline \multirow[t]{2}{*}{2} & 52.6 & $\mathrm{CH}_{2}$ & A: $3.55, m$ & 2B, 3A, (3B) & $3 a, 8 a$ \\
\hline & & & B: $2.58, \mathrm{~m}$ & $2 \mathrm{~A}, 3 \mathrm{~A}, 3 \mathrm{~B}$ & n.d. \\
\hline \multirow[t]{2}{*}{3} & 38.0 & $\mathrm{CH}_{2}$ & A: $2.39, \mathrm{dt}(13.1,6.2)$ & $2 \mathrm{~A}, 2 \mathrm{~B}, 3 \mathrm{~B}$ & $3 \mathrm{a}, 3 \mathrm{~b}, 3 \mathrm{a}-\mathrm{Me}$ \\
\hline & & & B: $2.23, \mathrm{dd}(13.1,5.5)$ & $(2 \mathrm{~A}), 2 \mathrm{~B}, 3 \mathrm{~A}$ & $3 a, 3 b, 8 a$ \\
\hline $3 a$ & 53.9 & $\mathrm{C}_{\mathrm{q}}$ & & & \\
\hline $3 b$ & 136.2 & $\mathrm{C}_{\mathrm{q}}$ & & & \\
\hline 4 & 122.9 & $\mathrm{CH}$ & $7.02, \mathrm{~d}(2.1)$ & 6 & $5,6,7 \mathrm{a}$ \\
\hline 5 & 125.8 & $\mathrm{C}_{\mathrm{q}}$ & & & \\
\hline 6 & 129.0 & $\mathrm{CH}$ & $7.15, \mathrm{dd}(8.4,2.1)$ & 4,7 & $4,5,7 \mathrm{a}$ \\
\hline 7 & 109.5 & $\mathrm{CH}$ & $6.52, \mathrm{~d}(8.4)$ & 6 & $3 b, 5$ \\
\hline $7 \mathrm{a}$ & 148.8 & $\mathrm{C}_{\mathrm{q}}$ & & & \\
\hline $8 \mathrm{a}$ & 94.6 & $\mathrm{CH}$ & $5.14, \mathrm{~s}$ & & $\begin{array}{l}2,3,3 \mathrm{~b}, 7 \mathrm{a}, 3 \mathrm{a}-\mathrm{Me}, \\
8-\mathrm{Me}\end{array}$ \\
\hline 1-Me & 33.9 & $\mathrm{CH}_{3}$ & $2.73, \mathrm{~s}$ & & $2,8 \mathrm{a}$ \\
\hline 3a-Me & 25.8 & $\mathrm{CH}_{3}$ & $1.51, \mathrm{~s}$ & & $3,3 a, 3 b, 8 a$ \\
\hline 8-Me & 37.9 & $\mathrm{CH}_{3}$ & $3.09, \mathrm{~s}$ & & $7 \mathrm{a}, 8 \mathrm{a}$ \\
\hline
\end{tabular}




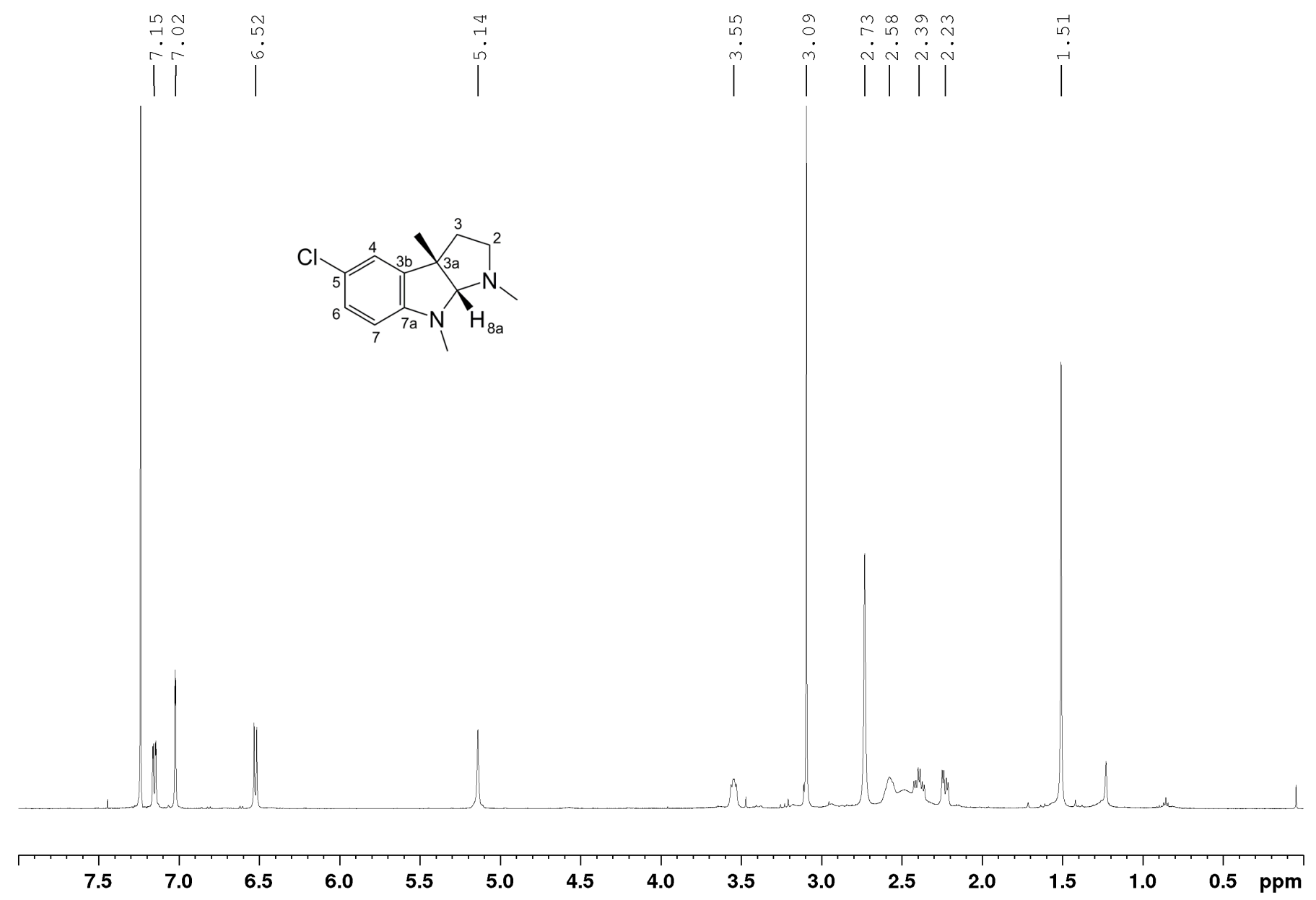

Figure S56. ${ }^{1} \mathrm{H}$ NMR spectrum $(600 \mathrm{MHz})$ of chlorophysostigmine (7d) in chloroform- $d$. 


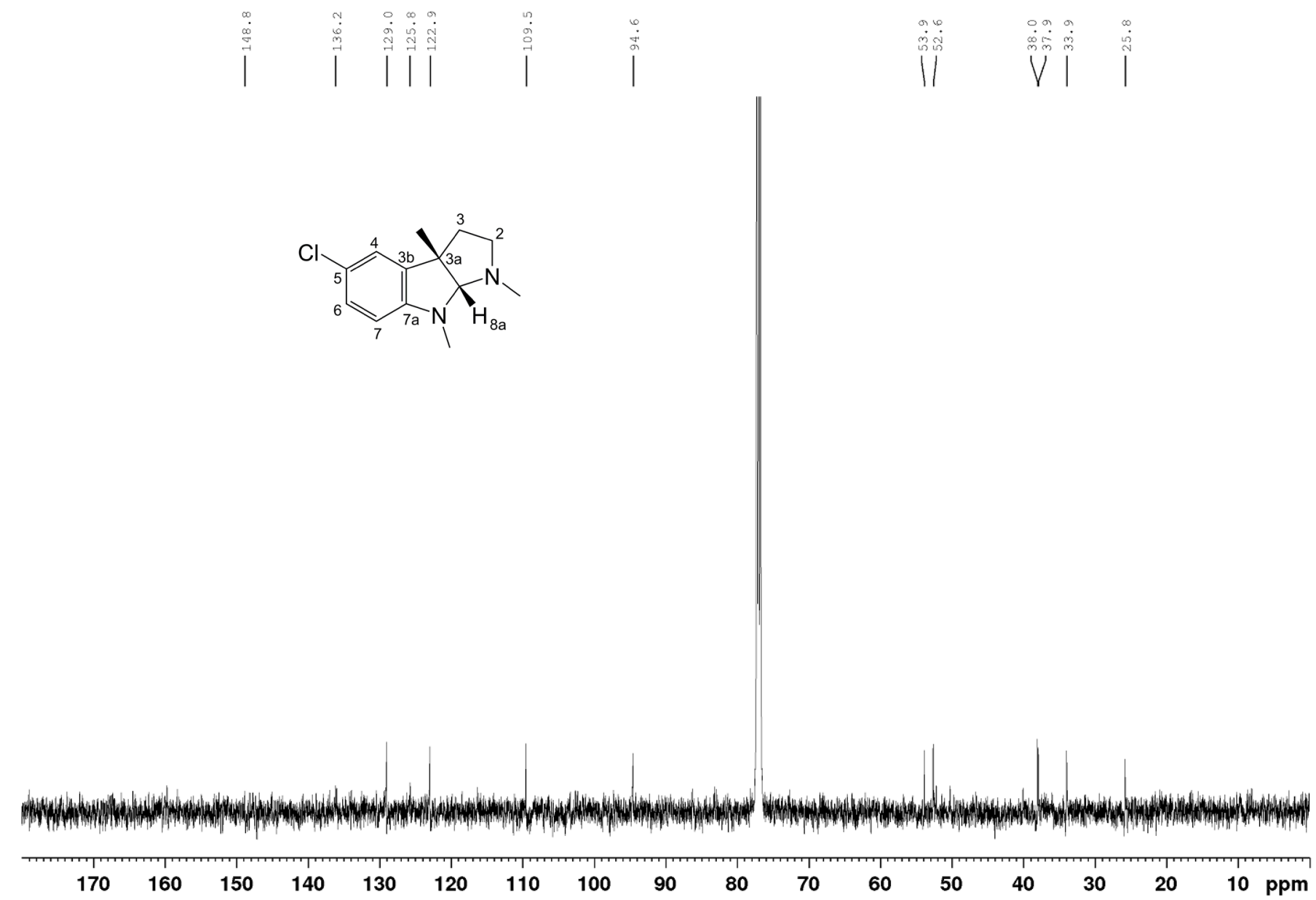

Figure S57. ${ }^{1} \mathrm{H}$-decoupled ${ }^{13} \mathrm{C}$ NMR spectrum $(150 \mathrm{MHz})$ of chlorophysostigmine (7d) in chloroform- $d$. 


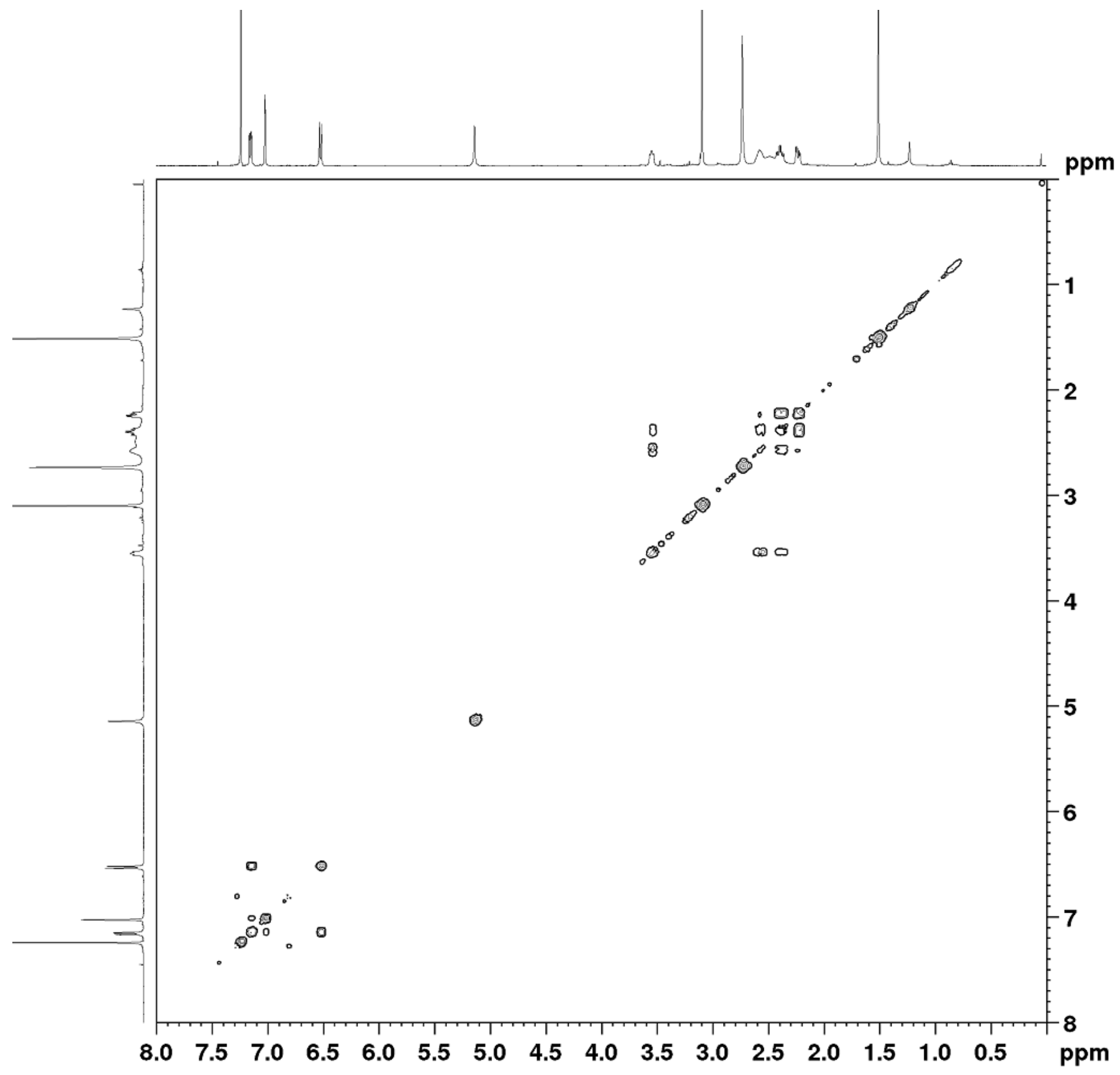

Figure S58. COSY spectrum of chlorophysostigmine (7d) in chloroform- $d$. 


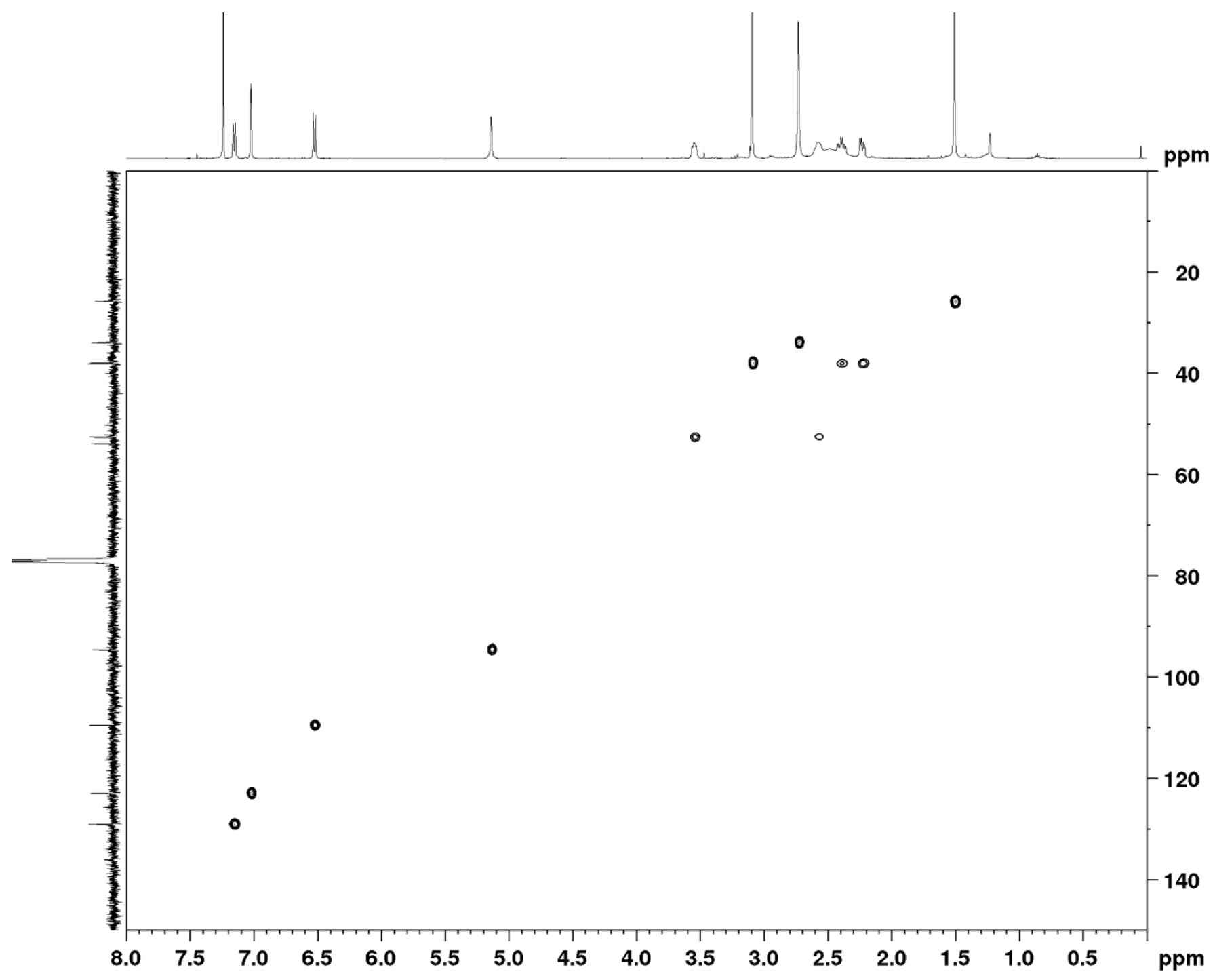

Figure S59. HSQC spectrum of chlorophysostigmine (7d) in chloroform- $d$. 


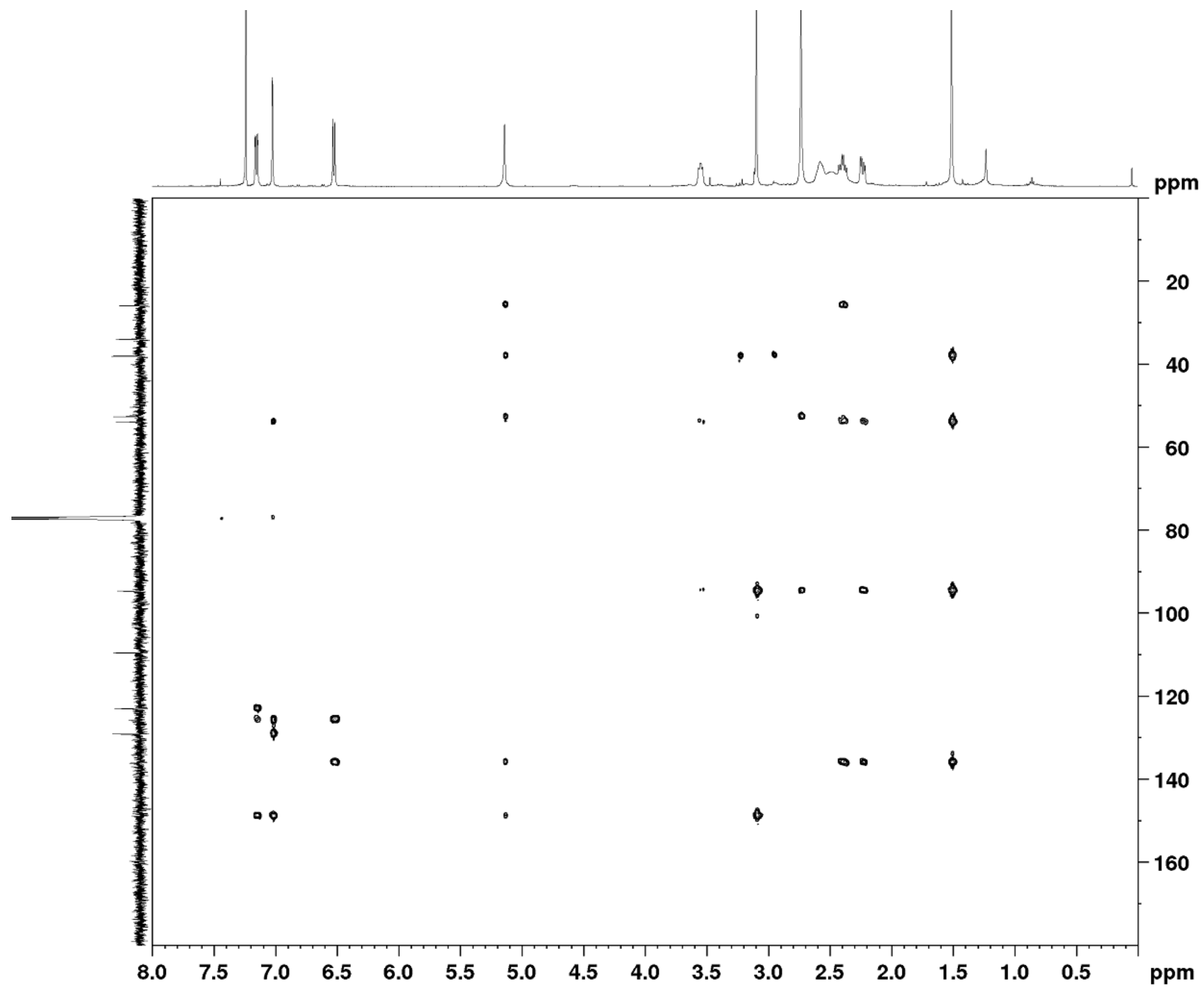

Figure S60. HMBC spectrum of chlorophys ostigmine (7d) in chloroform- $d$. 
Table S12. NMR data of bromophysostigmine (7e) in chloroform- $d$.

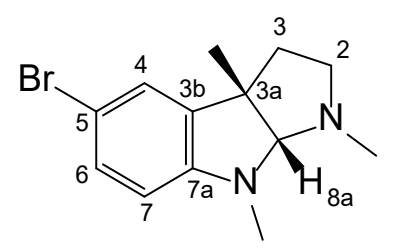

\begin{tabular}{|c|c|c|c|c|c|}
\hline $\bar{Z}$ & $\delta_{\mathrm{C}}$ & type & $\delta_{\mathrm{H}}, \mathrm{M}(J$ in $\mathrm{Hz})$ & COSY & $\mathrm{HMBC}\left({ }^{1} \mathrm{H} \rightarrow{ }^{13} \mathrm{C}\right)$ \\
\hline 2 & & & B: $2.59, \mathrm{~m}$ & $2 \mathrm{~A}, 3 \mathrm{~A}, 3 \mathrm{~B}$ & n.d. \\
\hline \multirow[t]{2}{*}{3} & 38.0 & $\mathrm{CH}_{2}$ & A: $2.38, \mathrm{dt}(13.2,6.3)$ & $2 \mathrm{~A}, 2 \mathrm{~B}, 3 \mathrm{~B}$ & 3a, 3b, 3a-Me \\
\hline & & & B: $2.25, \mathrm{dd}(13.2,5.4)$ & $(2 \mathrm{~A}), 2 \mathrm{~B}, 3 \mathrm{~A}$ & $3 \mathrm{a}, 3 \mathrm{~b}, 8 \mathrm{a}$ \\
\hline $3 b$ & 136.3 & $\mathrm{C}_{\mathrm{q}}$ & & & \\
\hline 4 & 125.8 & $\mathrm{CH}$ & $7.16, \mathrm{~d}(1.9)$ & 6 & $3 a, 5,6,(7), 7 a$ \\
\hline 5 & 112.9 & $\mathrm{C}_{\mathrm{q}}$ & & & \\
\hline 6 & 132.0 & $\mathrm{CH}$ & $7.31, \mathrm{dd}(8.4,1.9)$ & 4,7 & $4,5,7 \mathrm{a}$ \\
\hline 1-Me & 34.1 & $\mathrm{CH}_{3}$ & $2.75, \mathrm{~s}$ & & $2,8 \mathrm{a}$ \\
\hline 3a-Me & 25.7 & $\mathrm{CH}_{3}$ & $1.50, \mathrm{~s}$ & & $3,3 a, 3 b, 8 a$ \\
\hline 8-Me & 37.7 & $\mathrm{CH}_{3}$ & $3.10, \mathrm{~s}$ & & $7 \mathrm{a}, 8 \mathrm{a}$ \\
\hline
\end{tabular}




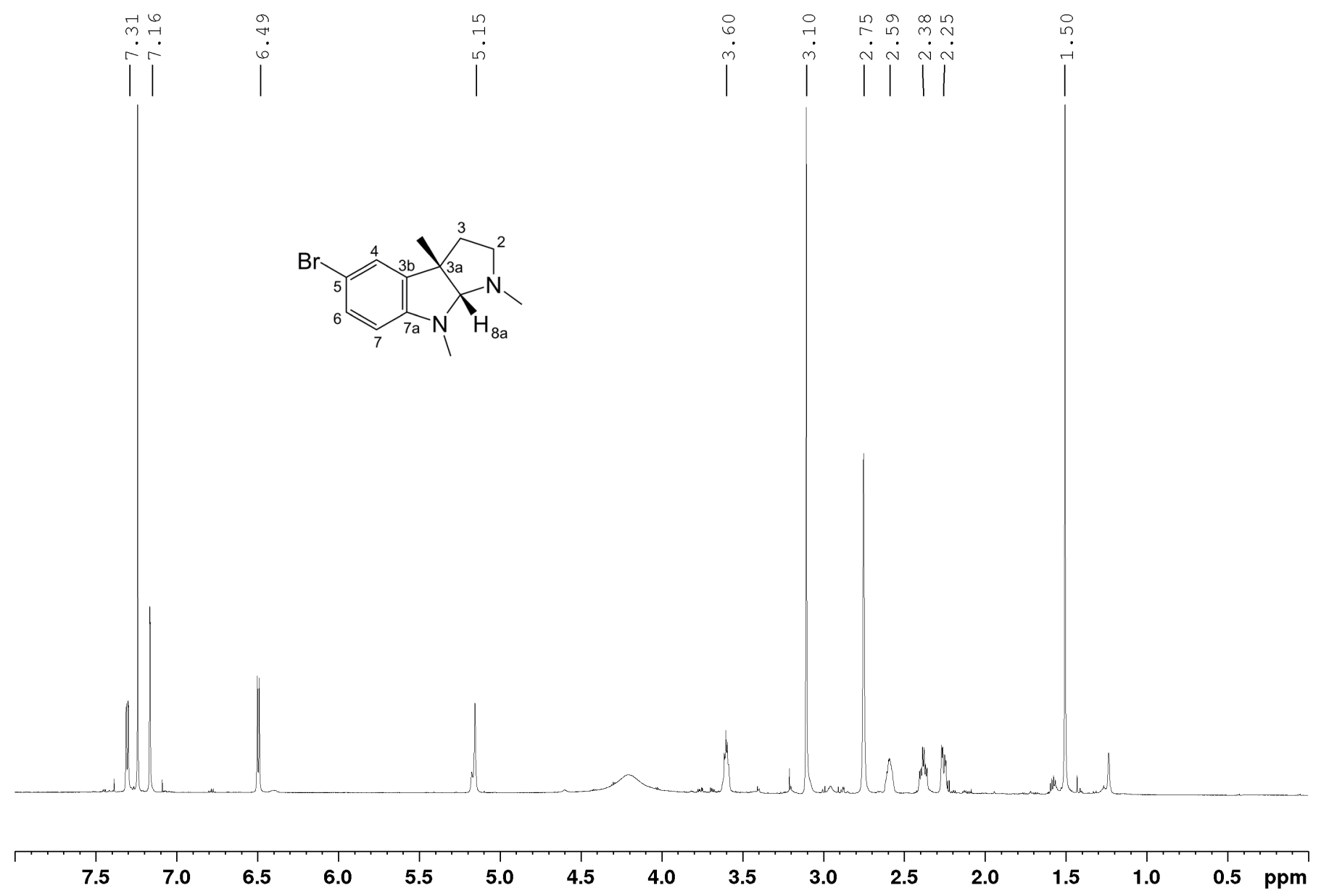

Figure S61. ${ }^{1} \mathrm{H}$ NMR spectrum $(700 \mathrm{MHz})$ of bromophysostigmine (7e) in chloroform- $d$. 


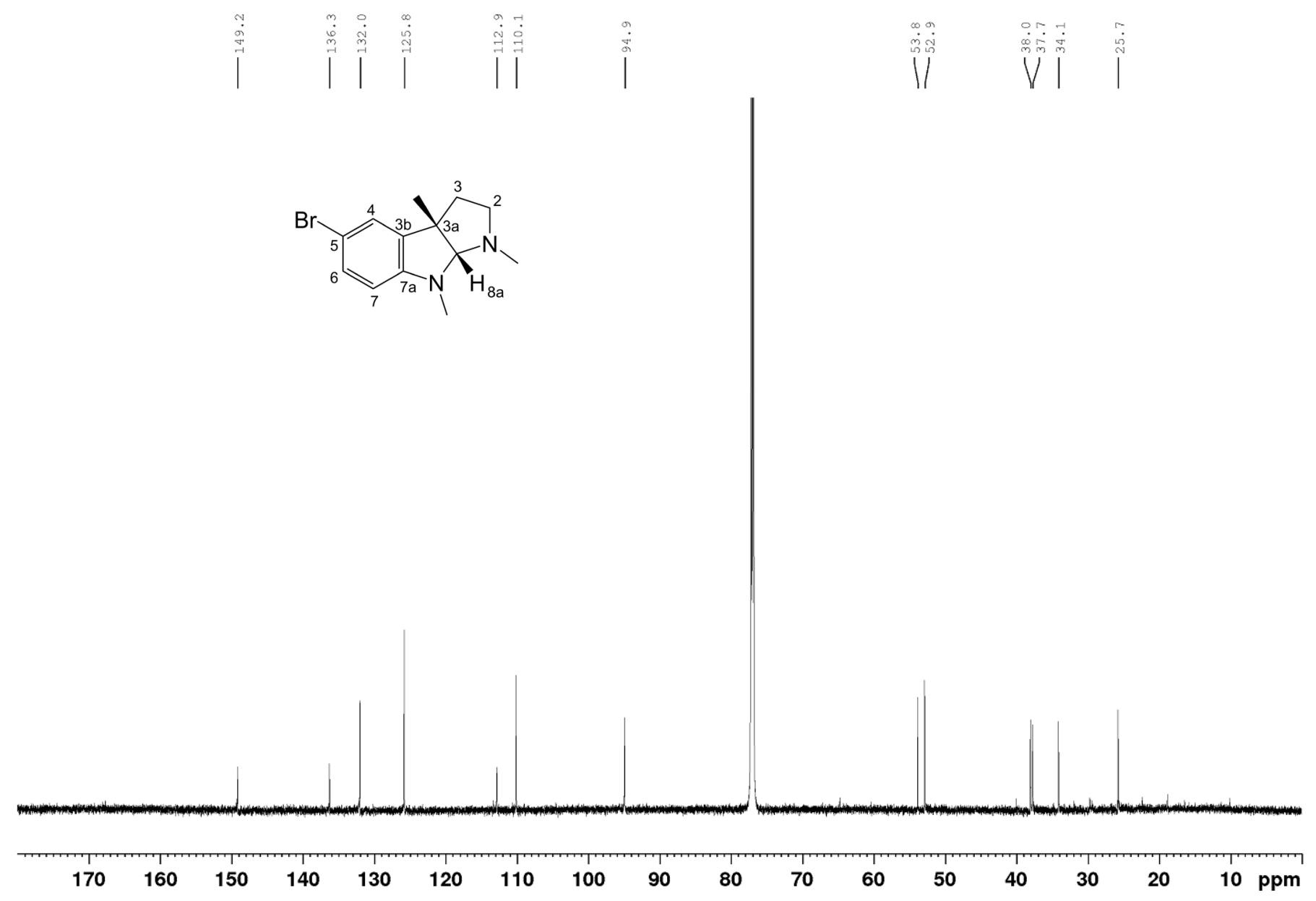

Figure S62. ${ }^{1} \mathrm{H}$-decoupled ${ }^{13} \mathrm{C}$ NMR spectrum $(175 \mathrm{MHz})$ of bromophysostigmine (7e) in chloroform- $d$. 


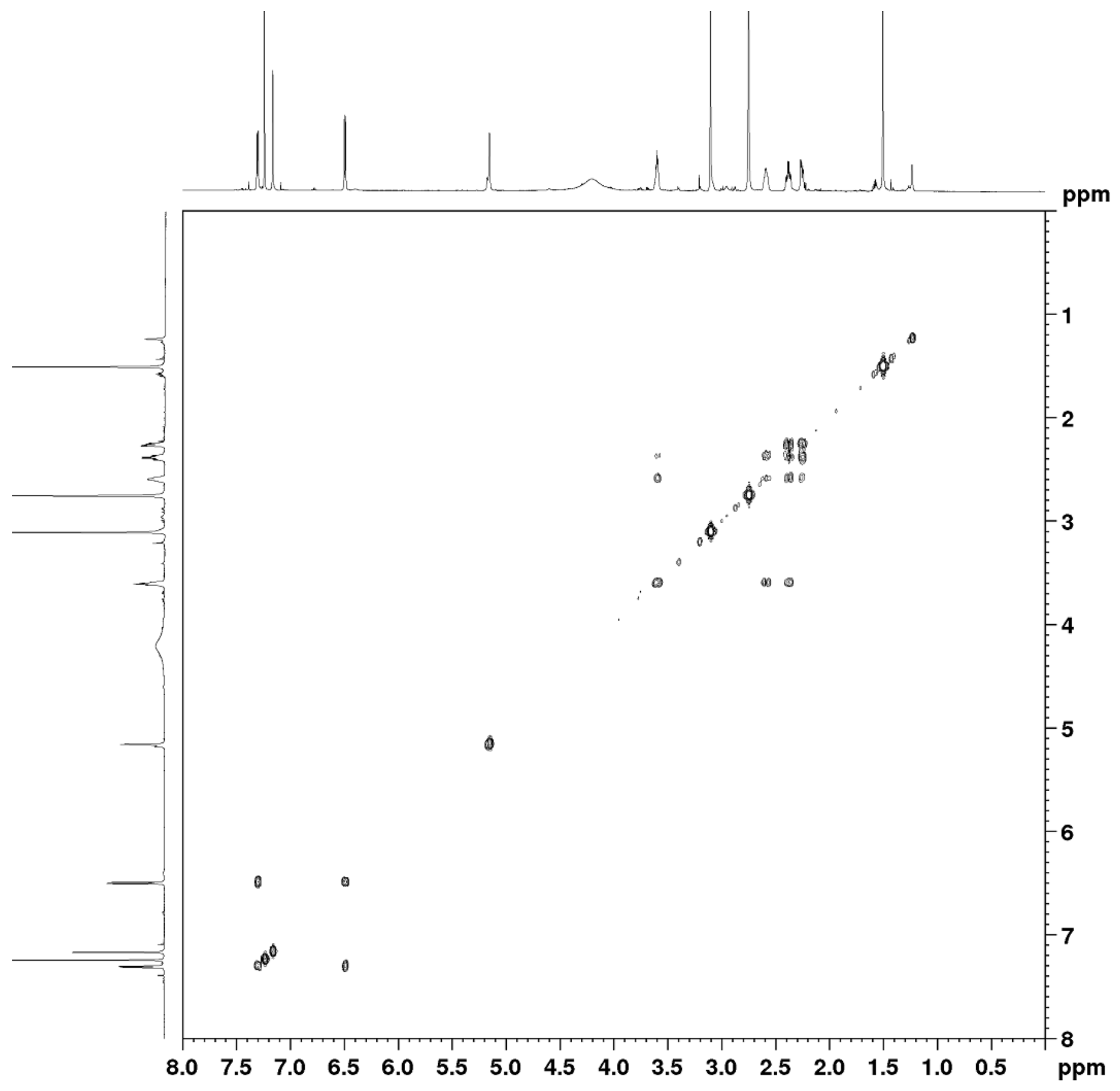

Figure S63. COSY spectrum of bromophysostigmine (7e) in chloroform- $d$. 


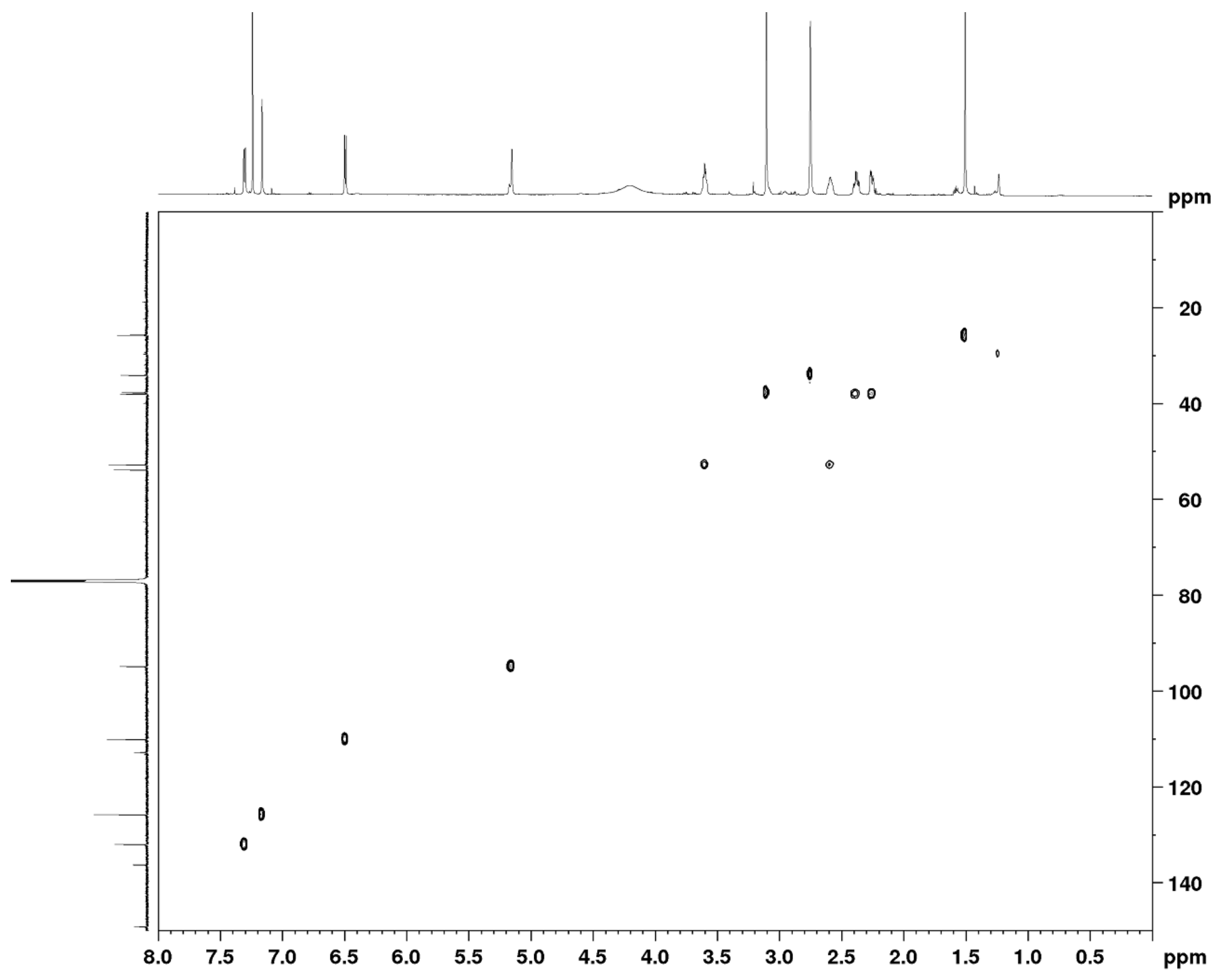

Figure S64. HSQC spectrum of bromophysostigmine (7e) in chloroform- $d$. 


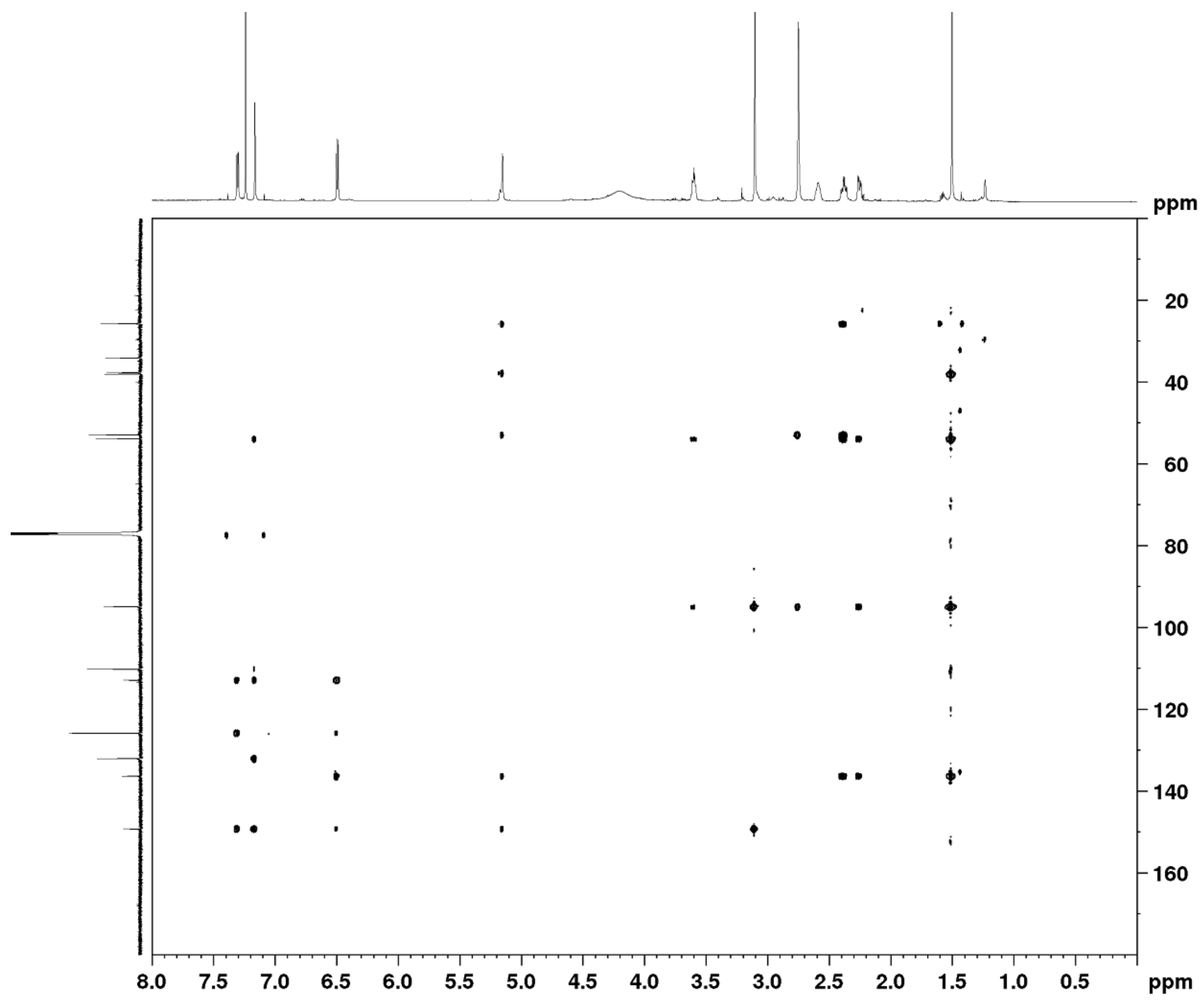

Figure S65. HMBC spectrum of bromophys ostigmine (7e) in chloroform- $d$. 
Table S13. NMR data of $n$-butanoylated intermediate $7 \mathbf{f}$ in methanol- $d_{4}$.

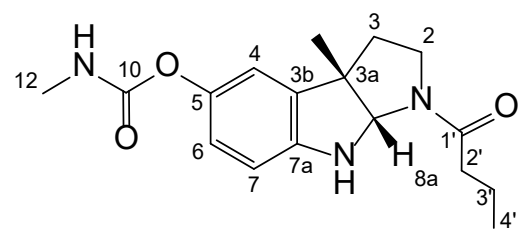

\begin{tabular}{|c|c|c|c|c|c|}
\hline \# & $\delta_{\mathrm{C}}$ & type & $\delta_{\mathrm{H}}, \mathrm{M}(J$ in $\mathrm{Hz})$ & COSY & $\mathrm{HMBC}\left({ }^{1} \mathrm{H} \rightarrow{ }^{13} \mathrm{C}\right)$ \\
\hline \multirow[t]{2}{*}{2} & 48.2 & $\mathrm{CH}_{2}$ & A: 3.90, ddd $(10.6,7.6,4.5)$ & $2 \mathrm{~B}, 3 \mathrm{~A}, 3 \mathrm{~B}$ & $3,3 a, 8 a$ \\
\hline & & & B: 3.44, ddd $(10.6,8.4,6.9)$ & $2 \mathrm{~A}, 3 \mathrm{~A}, 3 \mathrm{~B}$ & $3,3 \mathrm{a}$ \\
\hline \multirow[t]{2}{*}{3} & 38.8 & $\mathrm{CH}_{2}$ & A: $2.38, \mathrm{~m}$ & $2 \mathrm{~A}, 2 \mathrm{~B}, 3 \mathrm{~B}$ & 2, 3a, 3b, 8a, 3a-Me \\
\hline & & & B: $2.30, m$ & $2 \mathrm{~A}, 2 \mathrm{~B}, 3 \mathrm{~A}$ & 2, 3a, 3b, 8a, 3a-Me \\
\hline $3 a$ & 54.8 & $\mathrm{C}_{\mathrm{q}}$ & & & \\
\hline $3 b$ & 143.5 & $\mathrm{C}_{\mathrm{q}}$ & & & \\
\hline 4 & 119.3 & $\mathrm{CH}$ & $7.35, \mathrm{~d}(2.3)$ & 6 & $3 a, 5,6,7 \mathrm{a}$ \\
\hline 5 & 154.2 & $\mathrm{C}_{\mathrm{q}}$ & & & \\
\hline 6 & 124.4 & $\mathrm{CH}$ & $7.21, \mathrm{dd}(8.6,2.3)$ & 4,7 & $4,(5), 7 \mathrm{a}$ \\
\hline 7 & 121.2 & $\mathrm{CH}$ & $7.38, \mathrm{~d}(8.6)$ & 6 & $3 b, 5$ \\
\hline $7 \mathrm{a}$ & 132.7 & $\mathrm{C}_{\mathrm{q}}$ & & & \\
\hline $8 \mathrm{a}$ & 83.7 & $\mathrm{CH}$ & $5.69, \mathrm{~s}$ & & 2, 3, 3b, 7a, 3a-Me, 1' \\
\hline 10 & 157.1 & $\mathrm{C}_{\mathrm{q}}$ & & & \\
\hline 12 & 27.6 & $\mathrm{CH}_{3}$ & $2.80, \mathrm{~s}$ & & 10 \\
\hline 3a-Me & 23.8 & $\mathrm{CH}_{3}$ & $1.59, \mathrm{~s}$ & & $3,3 a, 3 b, 8 a$ \\
\hline 1 ' & 175.8 & $\mathrm{C}_{\mathrm{q}}$ & & & \\
\hline \multirow[t]{2}{*}{2} & 37.0 & $\mathrm{CH}_{2}$ & A: 2.48, ddd $(16.3,8.4,6.7)$ & 3 ' & $1^{\prime}, 3^{\prime}, 4^{\prime}$ \\
\hline & & & $\mathrm{B}: 2.36, \mathrm{~m}$ & 3 & $1^{\prime}, 3 ', 4 '$ \\
\hline 3 & 18.7 & $\mathrm{CH}_{2}$ & $1.69, \mathrm{~m}$ & $2^{\prime} \mathrm{A}, 2^{\prime} \mathrm{B}, 4^{\prime}$ & $1^{\prime}, 2^{\prime}, 4^{\prime}$ \\
\hline 4 & 14.1 & $\mathrm{CH}_{3}$ & $1.00, \mathrm{t}(7.4)$ & 3 ' & $2^{\prime}, 3^{\prime}$ \\
\hline
\end{tabular}




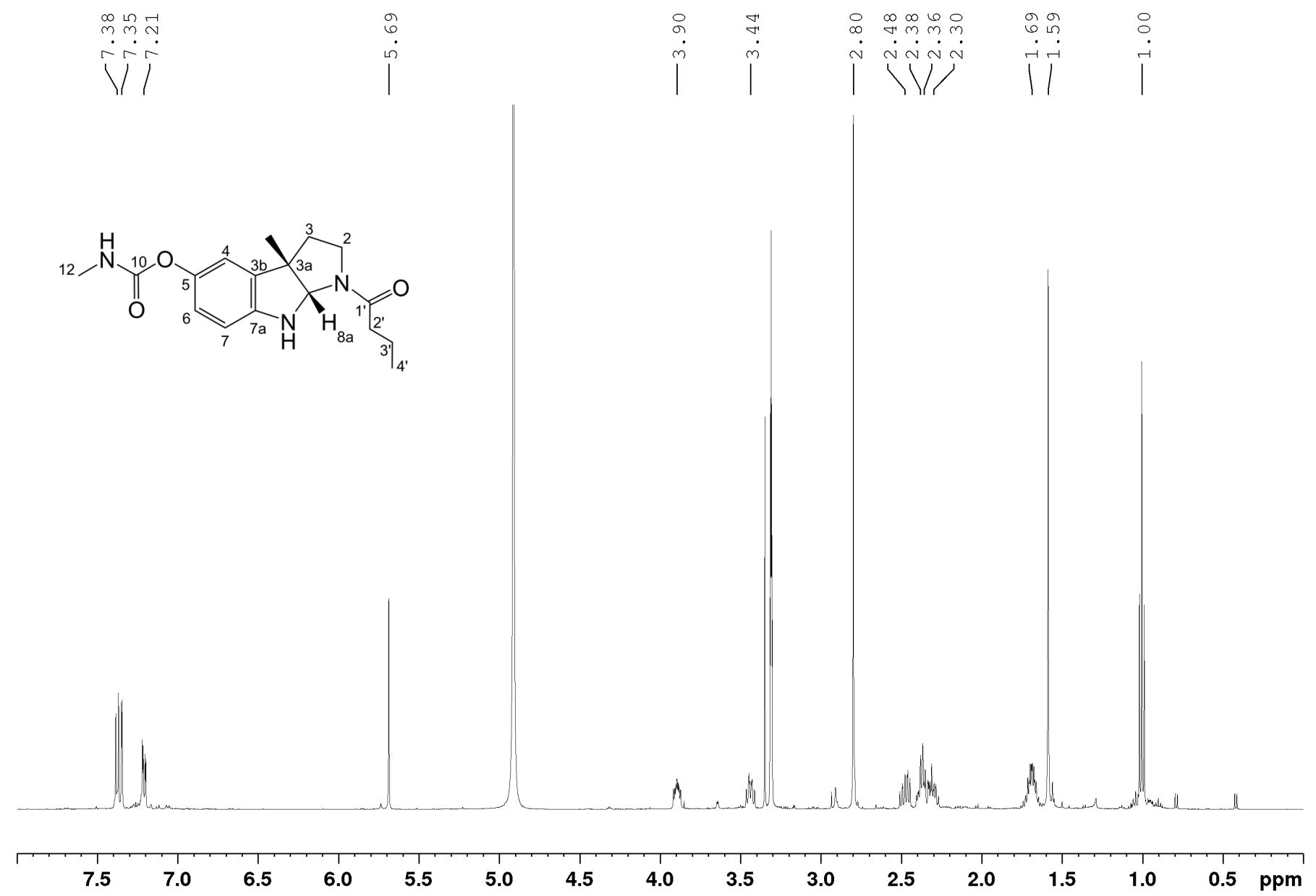

Figure S66. ${ }^{1} \mathrm{H}$ NMR spectrum $(600 \mathrm{MHz})$ of $n$-butanoylated intermediate $\mathbf{7 f}$ in methanol- $d_{4}$. 


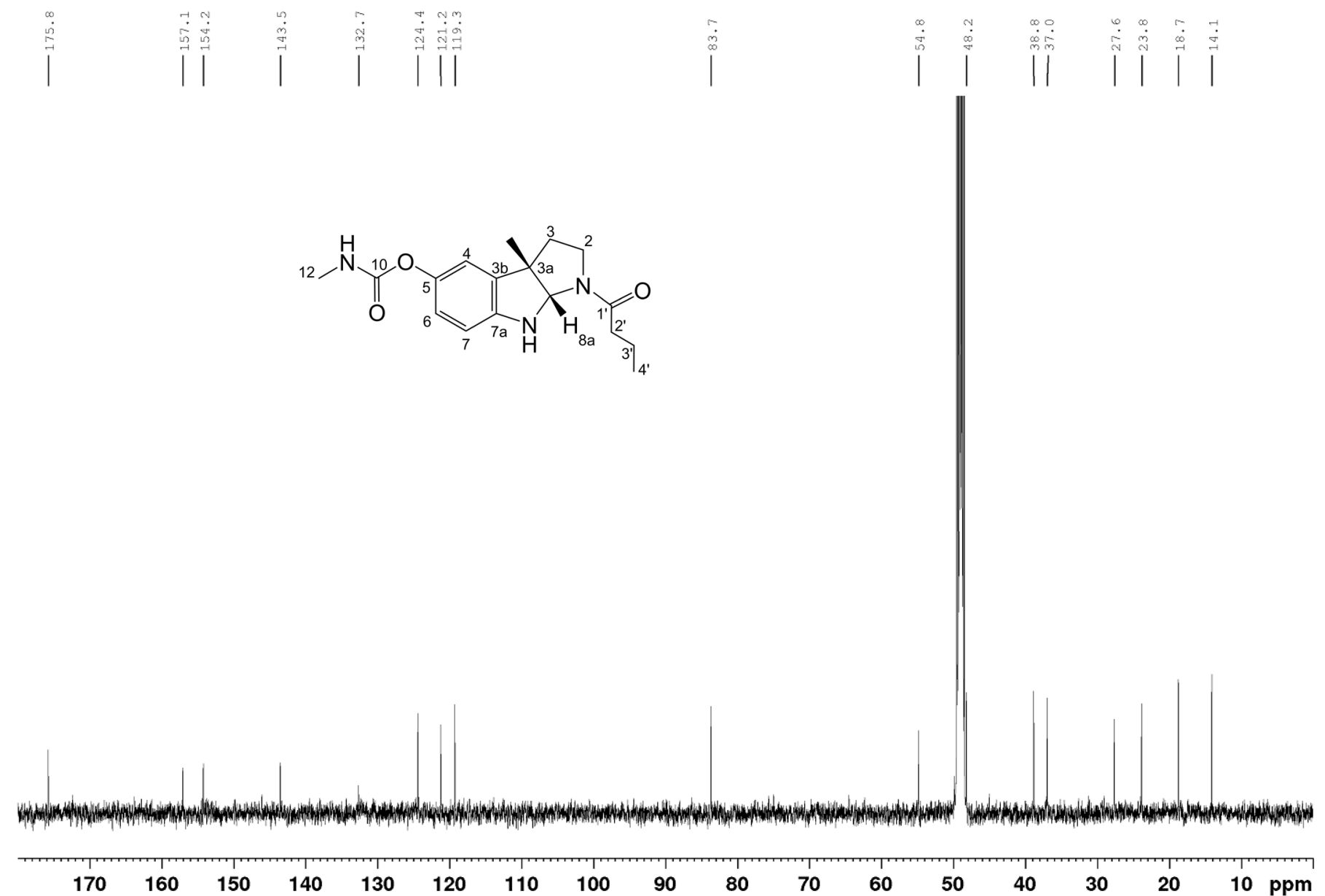

Figure S67. ${ }^{1} \mathrm{H}$-decoupled ${ }^{13} \mathrm{C}$ NMR spectrum $(150 \mathrm{MHz})$ of $n$-butanoylated intermediate $7 \mathbf{f}$ in methanol- $d 4$. 


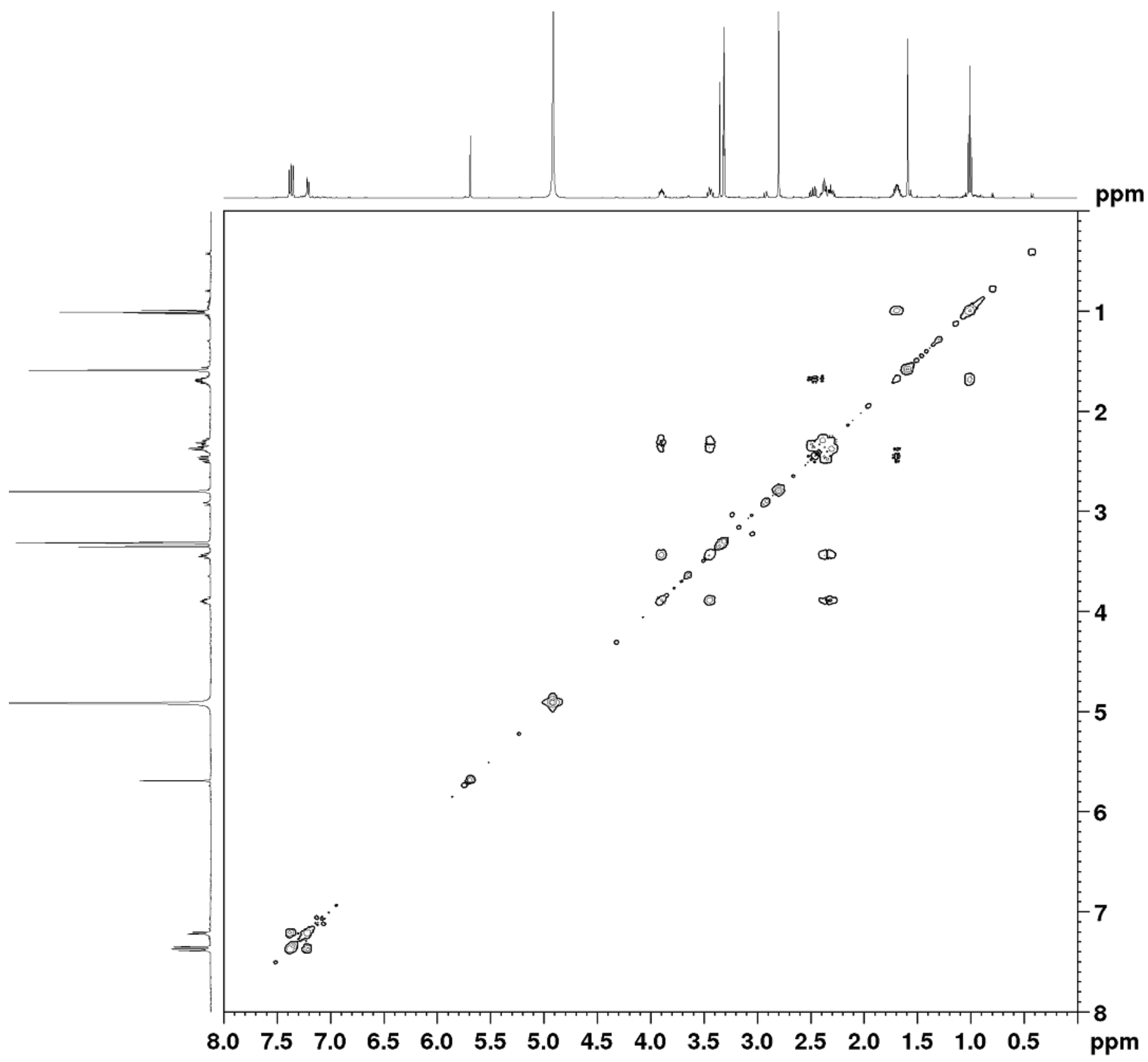

Figure S68. COSY spectrum of $n$-butanoylated intermediate $7 \mathbf{f}$ in methanol- $d_{4}$. 


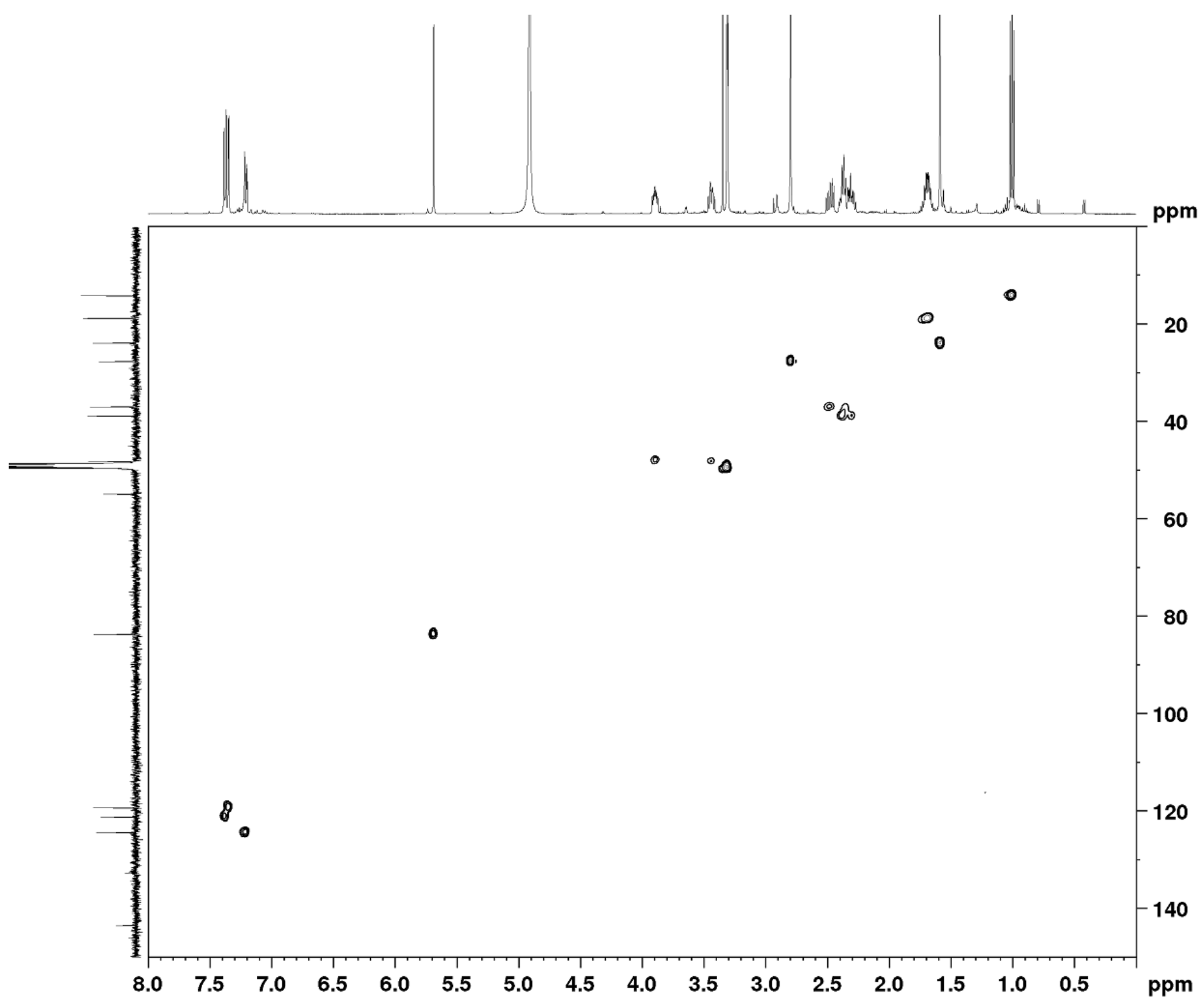

Figure S69. HSQC spectrum of $n$-butanoylated intermediate $7 \mathbf{f}$ in methanol- $d_{4}$. 


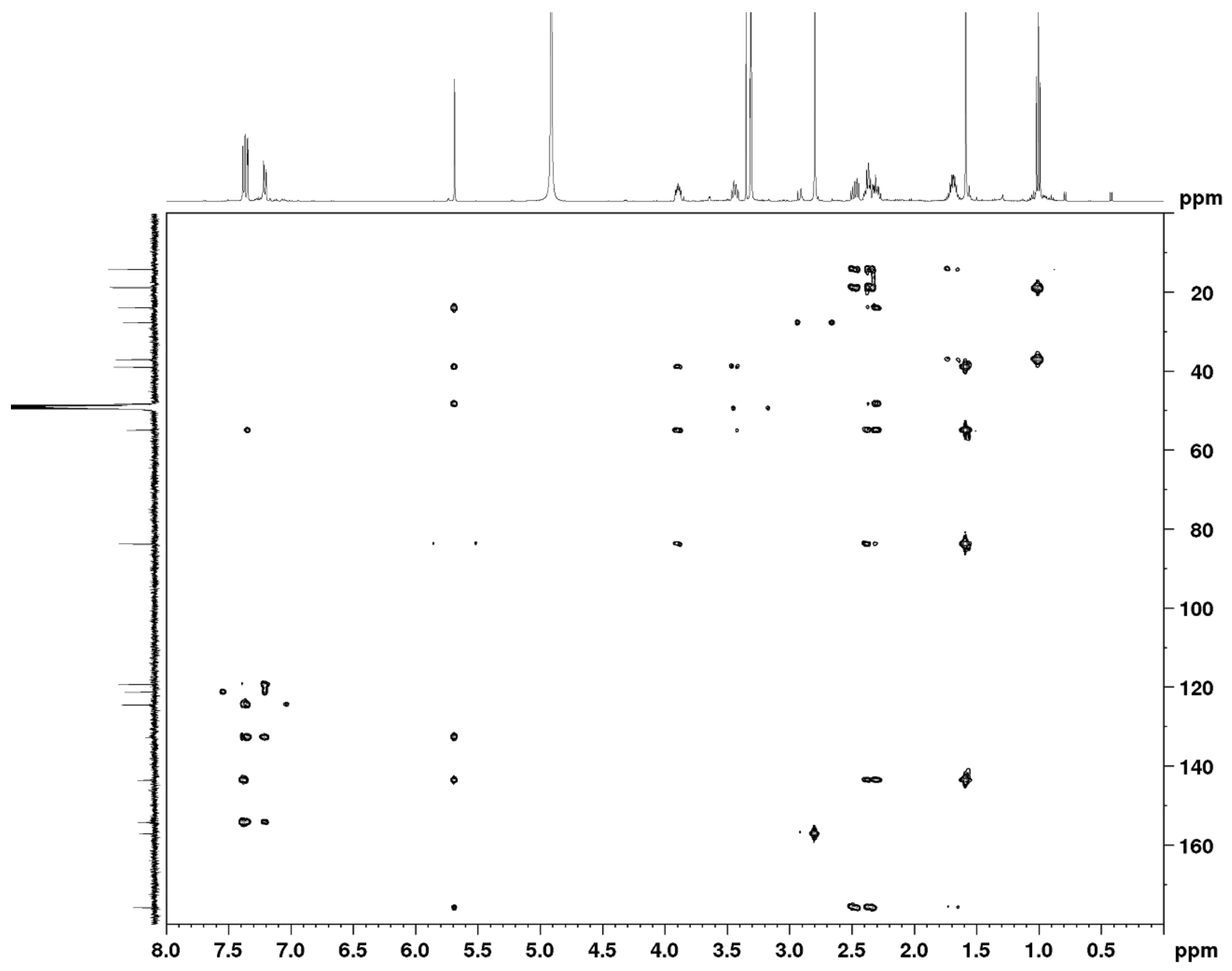

Figure S70. HMBC spectrum of $n$-butanoylated intermediate $7 \mathbf{f}$ in methanol- $d_{4}$. 


\section{References}

(1) Chen, Y.; Peng, Z. H.; Song, W.; Zhu, M. M.; Han, F. M. Anal.Lett. 2007, 40, 3256-3266.

(2) Dworkin, M.; Sadler, W. J. Bacteriol. 1966, 91, 1516-1519.

(3) Burchard, R. P. J. Bacteriol. 1970, 104, 940-947.

(4) Zhao, J.-Y.; Zhong, L.; Shen, M.-J.; Xia, Z.-J.; Cheng, Q.-X.; Sun, X.; Zhao, G.-P.; Li, Y.-Z.; Qin, Z.-J. Appl.Environ. Microbiol. 2008, 74, 1980-1987.

(5) Hanlon, W. A.; Martinez-Canamero, M.; Inouye, M.; Inouye, S. J. Bacteriol. 1995, 177, 7150-7154.

(6) Quan, J.; Tian, J. PloS one 2009, 4, e6441.

(7) Markl, C.; Clafshenkel, W. P.; Attia, M. I.; Sethi, S.; Witt-Enderby, P. A.; Zlotos, D. P. Arch. Pharm. 2011, 344, 666-674.

(8) Liu, J.; Ng, T.; Rui, Z.; Ad, O.; Zhang, W. Angew. Chem. Int. Ed. 2014, 53, 136-139.

(9) (a) Makrides, S. C. Microbiol.Rev. 1996,60, 512-538; (b) Riggs, P.; La Vallie, E. R.; McCoy, J. M. Curr. Protoc. Mol. Biol. 2001, Chapter 16, Unit16.4A.

(10) Wu, S. S.; Kaiser, D. J. Bacteriol. 1997, 179, 7748-7758.

(11) Brand, M.; Wang, L.; Agnello, S.; Gazzola, S.; Gall, F. M.; Raguž, L.; Kaiser, M.; Schmidt, R. S.; Ritschl, A.; Jelk, J.; Hemphill, A.; Mäser, P.; Bütikofer, P.; Adams, M.; Riedl, R. Angew. Chem. Int. Ed. 2021, 60, 15613-15621.

(12) Ellman, G. L.; Courtney, K.; Andres, V.; Featherstone, R. M. Biochem. Pharmacol. 1961, 7, 88-95.

(13) David, B.; Schneider, P.; Schaefer, P.; Pietruszka, J.; Gohlke, H. J. Enzyme Inhib. Med. Chem. 2021, 36, 491-496. 